INTERNATIONAL MONETARY FUND

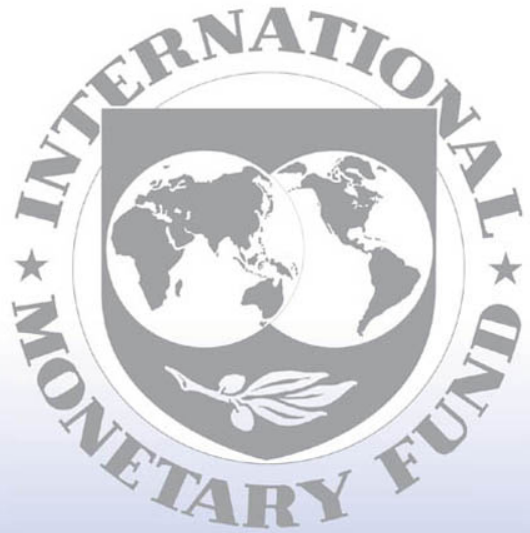

Staff

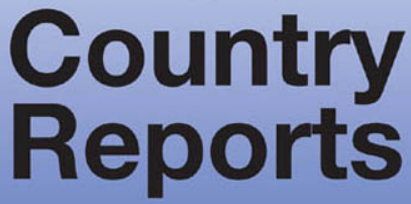




\title{
Mali-2010 Article IV Consultation, Fourth Review Under the Three-Year Arrangement Under the Extended Credit Facility, and Request for Modification of Performance Criteria
}

In the context of the Article IV consultation, Fourth Review Under the Three-Year Arrangement Under the Extended Credit Facility, and Request for Modification of Performance Criteria, the following documents have been released and are included in this package:

- The staff report for the 2010 Article IV Consultation, Fourth Review Under the Three-Year Arrangement Under the Extended Credit Facility, and Request for Modification of Performance Criteria, following discussions that ended on April 6, 2010 (last day of mission) with Mali's officials on economic developments and policies. Based on information available at the time of these discussions, the staff report was completed on June 29, 2010. The views expressed in the staff report are those of the staff team and do not necessarily reflect the views of the Executive Board of the IMF.

- A Press Release summarizing the views of the Executive Board as expressed during its June 16, 2010, discussion of the staff report that completed the request.

- A Public Information Notice

- A statement by the Executive Director for Mali

The documents listed below have been or will be separately released.

Letter of Intent sent to the IMF by Mali's authorities*

Technical Memorandum of Understanding*

*Also included in the Staff Report

The policy of publication of staff reports and other documents allows for the deletion of market-sensitive information.

Copies of this report are available to the public from International Monetary Fund $\bullet$ Publication Services $70019^{\text {th }}$ Street, N.W. $\bullet$ Washington, D.C. 20431

Telephone: (202) 623-7430 • Telefax: (202) 623-7201

E-mail: publications@imf.org Internet: http://www.imf.org

\author{
International Monetary Fund \\ Washington, D.C.
}


INTERNATIONAL MONETARY FUND

MALI

\begin{abstract}
Staff Report for the 2010 Article IV Consultation, Fourth Review Under the Three-Year Arrangement Under the Extended Credit Facility, and Request for Modification of Performance Criteria
\end{abstract}

\author{
Prepared by the African Department \\ (In consultation with other departments) \\ Approved by Roger Nord and Thomas Dorsey
}

June 29, 2010

Discussions: The discussions were held in Bamako during March 24-April 6, 2010 and in Washington during the 2010 Spring Meetings. The team comprised Messrs. Maret (head), Féler (Resident Representative), Camard, Ghazanchyan, and Razafimahefa (all AFR). The team met Prime Minister Modibo Sidibé, Minister of Finance and Economy Sanoussi Touré, National Director of the Central Bank of West African States (BCEAO) Oumar Ly, other officials, Mali's development partners, and representatives of civil society and the business community.

Exchange restrictions and regime: Mali, a member of the West African Economic and Monetary Union (WAEMU) accepted the obligations of Article VIII, Sections 2, 3, and 4 of the Fund's Articles of Agreement on June 1, 1996, and maintains an exchange system that is free of restrictions on current international transactions. The WAEMU's exchange regime is a conventional peg to the Euro.

Article IV consultation: The discussions focused on policies to prevent debt distress, reduce vulnerability to external shocks, and enhance growth prospects. Current risks to external stability are low, but policies to improve the competitiveness of the economy need to be pursued more vigorously. There are longer-term risks posed by rapid population growth and a potential decline in gold exports.

Fourth review under the ECF arrangement: The current three-year ECF arrangement was approved on May 28, 2008, in the amount of SDR 27.99 million (30 percent of quota). The first three reviews were completed in December 2008, July 2009, and February 2010, respectively. Staff recommends completion of the fourth review on the following basis:

- All quantitative performance criteria for end-December 2009 were met.

- All of the structural benchmarks have been observed, except one for which corrective actions are underway.

- The 2010 Supplementary Budget is in line with the understandings of the Third Review.

Publication: The authorities consent to the publication of this report. 


\section{Contents}

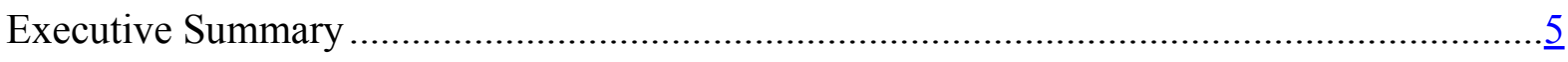

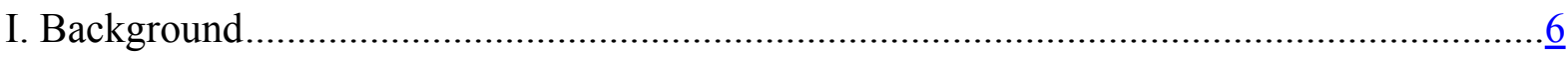

II. Recent Economic Developments and Program Implementation.............................................

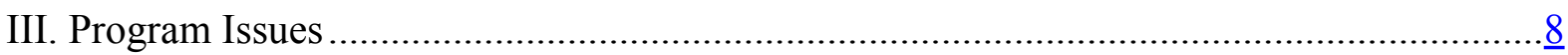

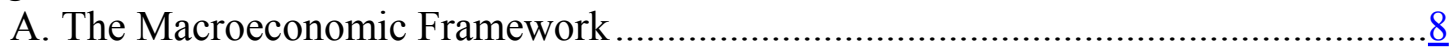

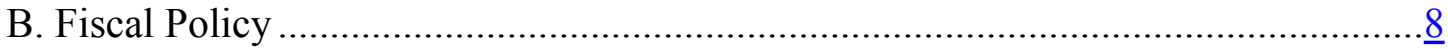

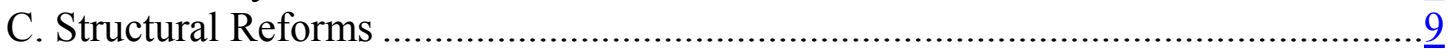

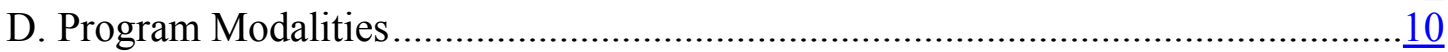

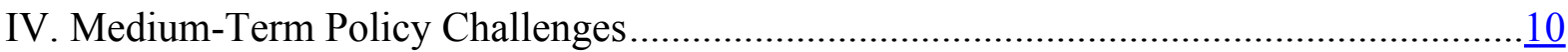

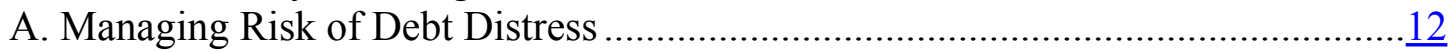

B. Managing Risk of External Shocks ..................................................................13

C. Managing Economic Growth Potential and Demographic Pressures …………......14

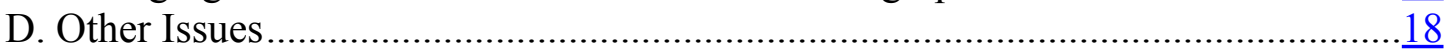

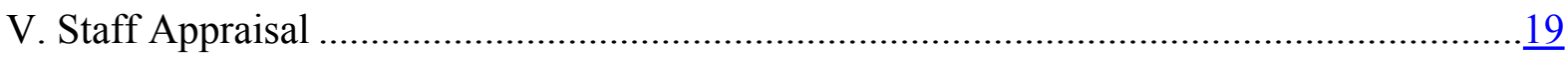

Figures

1. Macroeconomic Developments, 2008-12 ………....................................................

2. Selected Millennium Development Goals for 2015 .........................................................

Boxes

1. Status of the 2008 Article IV Consultation Recommendations ........................................11

2. Mining Sector: Macroeconomic Impacts and Prospects..................................................12

3. The 2008 Progress Report on the Poverty Reduction Strategy (PRSP) ……………….....16

4. Exchange Rate Assessment.....................................................................................

Tables

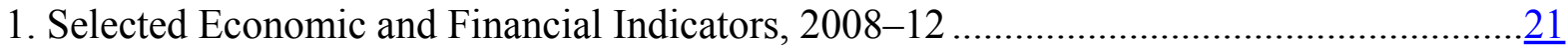

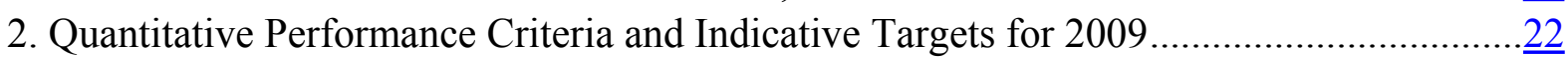

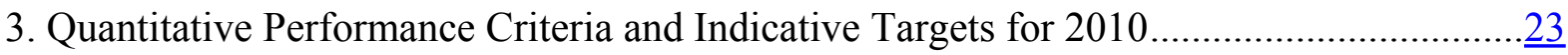

4. Structural Benchmarks for the Third and Fourth Reviews Under the ECF Program ...........24

5. Structural Benchmarks for the Fifth and Sixth Reviews Under the ECF Program ...............25

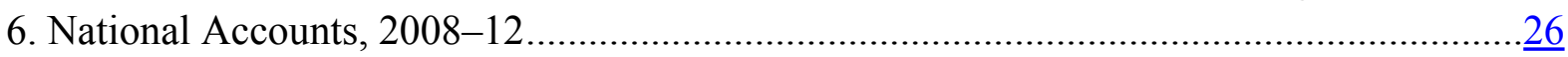

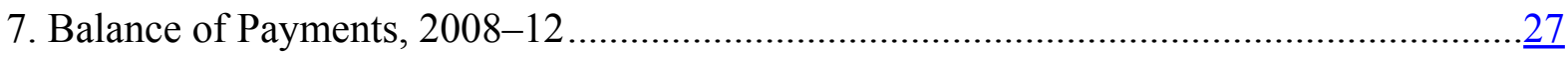

8. Central Government Consolidated Financial Operations, 2008-12 …................................29

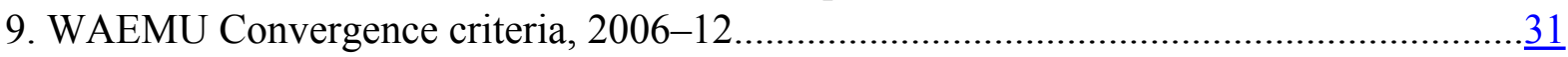

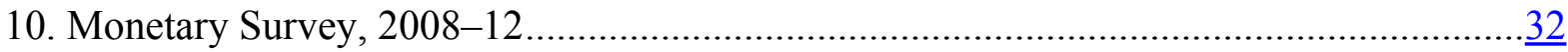

11. Financial Soundness Indicators for the Banking Sector, 2002-09 …………..................

12. Medium-Term Projections, 2008-15 …………....................................................... 
13. Millennium Development Goals, 1990-2008 …………................................................

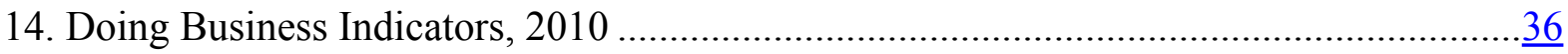

15. Indicators of Capacity to Repay the Fund, 2008-14 ...................................................

16. Schedule of Disbursements Under the ECF Arrangement, 2008-11 ...............................

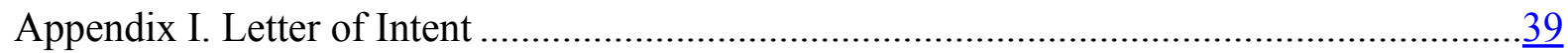

Attachment I. Technical Memorandum of Understanding ......................................... 


\section{ACRONYMS}

\begin{tabular}{|c|c|}
\hline BCEAO & Central Bank of West African States \\
\hline BDM & Banque de Développement du Mali (Development Bank of Mali) \\
\hline BHM & Banque de l'Habitat du Mali (Housing Bank of Mali) \\
\hline BIM & Banque Internationale du Mali (International Bank of Mali) \\
\hline CMDT & $\begin{array}{l}\text { Compagnie Malienne pour le Développement des Textiles (Cotton } \\
\text { Ginning Company of Mali) }\end{array}$ \\
\hline DeMPA & Debt Management Performance Assessment \\
\hline ECF & Extended Credit Facility \\
\hline EdM & Énergie du Mali (Energy Company of Mali) \\
\hline GIABA & $\begin{array}{l}\text { Inter-Governmental Action Group against Money Laundering in West } \\
\text { Africa }\end{array}$ \\
\hline HIPC & Highly Indebted Poor Countries \\
\hline MEFP & Memorandum of Economic and financial policies \\
\hline MDRI & Multilateral Debt Relief Initiative \\
\hline MDGs & Millennium Development Goals \\
\hline OdN & $\begin{array}{l}\text { Office du Niger (Authority in charge of irrigation and extension services } \\
\text { in the Niger river inland delta) }\end{array}$ \\
\hline PAGAM-GFP & $\begin{array}{l}\text { Programme d'action gouvernementale d'amélioration et de } \\
\text { modernisation de la gestion des finances publiques (Government Action } \\
\text { Program for Improving and Modernizing Public Finance) }\end{array}$ \\
\hline $\mathrm{PC}$ & Performance criterion \\
\hline PEFA & Public expenditure and financial accountability \\
\hline PRGF & Poverty Reduction and Growth Facility \\
\hline PRS & Poverty Reduction Strategy \\
\hline PRSP & Poverty Reduction Strategy Paper \\
\hline REER & Real effective exchange rate \\
\hline SOTELMA & Société de Télécommunications du Mali (Telephone Company of Mali) \\
\hline TMU & Technical Memorandum of Understandings \\
\hline VAT & Value-added tax \\
\hline WAEMU & West African Economic and Monetary Union \\
\hline
\end{tabular}




\section{Executive Summary}

The program supported by the Extended Credit Facility (ECF) remains on track. The implementation of the government's economic and financial program in 2009 was broadly satisfactory despite the global crisis. All quantitative targets were met at end-December 2009, and three of the four structural benchmarks of the review were observed; corrective actions for the fourth one are underway, including through the implementation of a new public accounting software.

Growth was sustained at 4.5 percent, average inflation declined to 2.2 percent, and the balance of payments improved markedly in 2009. These outcomes reflect a strong agricultural harvest, buoyant gold export prices, and lower oil prices, as well as prudent macroeconomic policies. The balance of payments benefited also from the equivalent of $5 \frac{1}{2}$ percentage points of GDP in exceptional external resources (privatization receipts and the SDR allocations).

The 2009 basic budget deficit- the overall budget balance excluding grants, foreignfinanced capital expenditure and spending financed by the Highly Indebted Poor Countries (HIPC) Initiative-was lower than programmed, at 1.4 percent of GDP, but the targeted reduction in pending bills was not fully achieved until end-March 2010.

The 2010 economic outlook remains positive, with a projected strengthening of economic activity. Discussions focused on the use of privatization proceeds amounting to 4 percent of GDP while maintaining macroeconomic stability. The mission welcomed the authorities' reaffirmation of their aim to limit the new basic budget deficit to no more than $2 \frac{1}{2}$ percent of GDP in 2010 and urged them to be fully transparent in the use of the privatization receipts.

The structural reform program is progressing satisfactorily, with a further strengthening of public finance management targeted in 2010. The privatization of the cotton parastatal CMDT and the reform program of the Housing Bank of Mali are on track.

Looking ahead, the policy challenges remain daunting. Maintaining external and internal sustainability will require the implementation of prudent debt and fiscal policies in the context of an expected decline of the mining sector, currently accounting for 75 percent of exports. Tackling vulnerabilities to external and natural shocks implies careful risk management strategies, the elaboration of sound contingent policies, and a diversification of economic activities. To that effect, the development of the private sector and the achievement of higher growth rates, which is also warranted by demographic pressures, require a more assertive development strategy. In line with previous recommendations, staff emphasized the importance of improving competitiveness, as well as the soundness of and prospects for the financial sector.

Staff supports the authorities' request for completion of the fourth ECF review. 


\section{BACKGROUND}

1. Mali's arrangement under the Extended Credit Facility (ECF) was approved in the context of the $\mathbf{2 0 0 8}$ food and fuel crisis, at the time of the last Article IV Consultation (SM/08/142, 5/5/08). The 2008-11 arrangement was heavily frontloaded to address financing needs stemming from the surge of world food and fuel prices that started to affect Mali in 2007. It aimed at preserving macroeconomic stability while achieving higher levels of growth and making credible forays in poverty reduction through prudent fiscal policies and complementary structural reforms. While inflation spiked to 13 percent in 2008, a good harvest yielded growth of 5 percent despite difficulties in the cotton sector, and the sharp deterioration of the external current account balance was mostly financed by private capital inflows (Tables 1 and 6-16, Figure 1). The basic fiscal deficit (that excludes grants, foreign-financed capital expenditure and HIPC Initiative financed spending) was stable at 1 percent of GDP, though financing constraints resulted in a significant buildup in the domestic payment float by the end of 2008 .

\section{RECENT ECONOMIC DEVELOPMENTS AND PRogram IMPLEMENTATION}

2. Economic performance in $\mathbf{2 0 0 9}$ was good. The unwinding of the 2008 fuel and food shocks played an important role in offsetting the negative effects of the global downturn, and a good harvest contributed to the turnaround. Inflation declined to 2.2 percent, growth was better than expected at 4.5 percent, and the balance of payments and the external current account recorded significant improvements, buoyed by high gold export prices and exceptional capital inflows. The sale of 51 percent of state telecom firm SOTELMA was completed in July, yielding US\$0.4 billion (4 percent of GDP). This, together with the allocation of 74 million SDRs in August, contributed to a substantial increase in the international reserves of the West African Economic and Monetary Union (WAEMU) in 2009. Program implementation remained satisfactory with all quantitative performance criteria and benchmarks observed at end-September and end-December 2009. ${ }^{1}$ The structural benchmarks for the fourth ECF review were all completed except for one, which was partially observed and for which remedial actions are underway (Tables 2 and 4).

\footnotetext{
${ }^{1}$ Preliminary data suggest that all end-March 2010 quantitative benchmarks were observed as well.
} 
Figure 1. Mali: Macroeconomic Developments, 2008-12
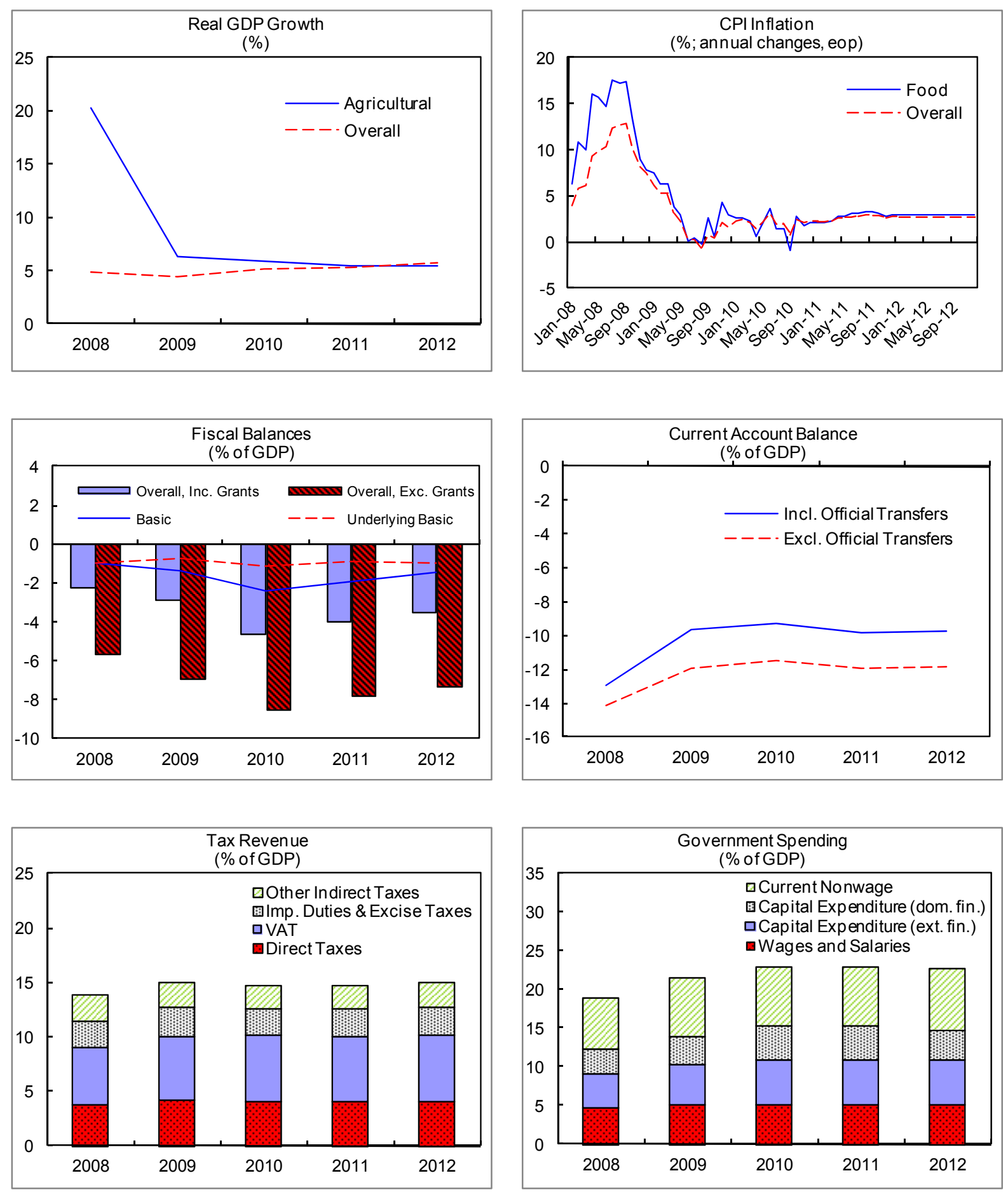

Source: : Malian authorities; and IMF staff estimates 
3. Fiscal performance was satisfactory in most respects. The basic fiscal deficit was lower than programmed, at 1.4 percent of GDP, but budgetary execution at the end of 2009 was hampered by delays in foreign aid disbursements, the release of large amounts of budget allocations when expenditure restraints were lifted, and enduring weaknesses in cashflow forecasting and management, which resulted in a temporary surge in pending bills. Consequently, the reduction in pending bills and domestic arrears targeted at endDecember 2009 was only met at end-March 2010. In addition, new Value Added Tax (VAT) credits have been recorded as unpaid, pending the implementation of an effective reimbursement system that is scheduled for end-2010. Improved domestic debt and cash management will be one focus of ongoing reforms at the Treasury in 2010, with the help of a recently-arrived Fund resident expert.

\section{Program Issues}

\section{A. The Macroeconomic Framework}

4. Economic prospects have remained positive since the third program review. With a better than expected 2009 outturn and the implementation of a modest fiscal impulse, growth projections for 2010 and beyond have been increased slightly. Over the medium term, continued solid growth in agriculture, including a post-privatization renewal of cotton production, is expected to anchor growth in the 5-6 percent range. With prudent monetary policies at the regional level and prospects of a reasonable harvest, average inflation remains subdued and projected at around 2 percent in 2010.

\section{Buttressed by an additional improvement in the terms of trade linked to} buoyant gold and cotton prices and declining oil prices, the external current account deficit will decline in 2010. The weakening of the CFA franc will also contribute to a medium-term strengthening of the trade balance, despite the projected higher level of imports as a result of the fiscal stimulus package being implemented over 2010-12 (see below).

\section{B. Fiscal Policy}

6. In keeping with the policy commitments made at the time of the third review under the ECF arrangement, the authorities are implementing a modest fiscal stimulus package aimed at sustaining higher levels of growth. The package is financed by the privatization revenue of SOTELMA and spread over the period 2010-12, with a view to preserving macroeconomic stability, remaining compatible with the absorptive capacity of the economy, and maintaining the long term sustainability of public finances. ${ }^{2}$ Funds have been allocated to the eight priority areas of President Touré's 2007-12

\footnotetext{
${ }^{2}$ Details of the expenditure program financed with the proceeds from selling SOTELMA are set out in Table 1 of the authorities' Letter of Intent.
} 
Economic and Social Development Plan. About one-fourth of the money is destined for infrastructure, agriculture, and the social sectors; one-fourth for counterpart funds to cofinance public investment with donors; another one-fourth for paying down domestic debt; and the balance for housing construction, decentralization, and other uses. For 2010, the authorities have introduced a supplementary 2010 budget law to the National Assembly that sets a target of 2.4 percent of GDP for the basic fiscal deficit, compared with a 2009 outcome of 1.4 percent of GDP. Of this target, 1.3 percent of GDP consists of nonrecurrent expenditures financed by privatization receipts under the targeted expenditure program announced by President Touré in November 2009. This leaves the underlying basic deficit at a level equivalent of 1.1 percent of GDP, which is comparable to recent years and broadly sustainable in the long run.

\section{As envisaged, the revised budget law for $\mathbf{2 0 1 0}$ also incorporates more realistic} allocations to support the agricultural sector. New spending equivalent to 1.4 percent of GDP have been introduced, with nearly half accounted for the by non-recurrent expenditure financed by SOTELMA revenue. The other half reflects additional support to the cotton sector and fertilizer subsidies ( $1 / 2$ percent of GDP), a Constitutional referendum to approve a strengthening of state institutions (notably the creation of a Senate and the strengthening of the Supreme Court's financial oversight role), and higher domestic interest payments. ${ }^{3}$ The authorities did not consider that the drought in Eastern Mali would have a significant budgetary impact, despite the release of cereals from government stocks, as the international community is also providing assistance to those affected.

8. Staff regretted that the revised budget law did not include the specific cuts that are required to achieve the stated basic deficit targets, but the authorities advocated that they have the legal powers to regulate budget execution within the approved budget ceilings. While firmly committed to the basic deficit targets, they highlighted their track record and the need for flexibility in budget execution to achieve these targets. They considered that, through a judicious reallocation of existing budget allocations, they have sufficient fiscal space within existing budgetary envelopes to achieve the required savings while addressing other potential expenditure needs within the deficit target.

\section{Structural Reforms}

9. Discussions on structural reforms of the 2010 program focused on maintaining the momentum of reforms, including those that should come to fruition during the year. The most prominent of these are the privatization of cotton ginning company (CMDT) and the continued restructuring of the Housing Bank of Mali (BHM) with a view

\footnotetext{
${ }^{3}$ Ex-post control of expenditure in Mali is conducted by both an Office of the Auditor-General and a branch of the Supreme Court. The planned amendments to the Constitution will make the accounts section of the Supreme Court more autonomous and allow for an enhanced role. In addition to these two bodies, there are a number of other agencies within the executive branch auditing public finances.
} 
to privatizing it in 2012. Several public finance reforms are expected as well: the new Treasury accounting system should be ready in time for the start of the 2011 budget; a new budget reporting presentation ("TOFE") incorporating earlier work on government accounts in the banking system should be operational at end-June; and improved forecasting techniques should strengthen the role of the treasury cash flow plan. Other actions stemming from the reform programs of the Tax and Customs Departments, such as the introduction of a medium taxpayer unit, should also show results. Most of these reforms have been inscribed in the PAGAM II, the second-generation multi-donor PFM reform program to be formally launched in the coming months.

\section{The authorities are planning complementary reforms to strengthen further} public finances. In particular, they intend to put an end to the problem of VAT credit arrears by establishing a new system for issuing refunds promptly. They are embarking on a modernization and rationalization of their tax system in line with regional guidelines and revenue objectives, which will start with the elaboration of a reform program by the end of 2010 and for which technical assistance from the Fund is being sought. Following a World Bank diagnostic audit, a number of measures are also being taken to strengthen public debt management.

\section{Program Modalities}

\section{Program monitoring will be carried out on the basis of quantitative} performance criteria and benchmarks in Table 3. The initial targets for end-June, endSeptember, and end-December 2010 have been modified, if appropriate, to take into account the fiscal stimulus package to be financed by SOTELMA revenue and the greater reduction of pending bills required in 2010 by the temporary surge of the float at end-2009. In light of these new developments, the authorities have requested approval of the revised quantitative performance criteria and benchmarks for end-June, and staff supports this request. The revised program also includes a quantitative benchmark on poverty-reducing spending, which, in line with the requirements of the ECF instrument, covers mostly current expenditure on education and health and aims at supporting the sectoral objectives set in the Poverty Reduction Strategy Paper (PRSP).

\section{Structural benchmarks for end-December remain focused on strengthening} public finances and the financial sector (Table 5). They cover an audit of the renewed activities of the BHM, the introduction of a VAT credit reimbursement system, the elaboration of a tax reform program, and the implementation of a new public accounting system at the Treasury.

\section{Medium-Term Policy Challenges}

13. Mali's economic prospects beyond the immediate program period hinge on the authorities' success in maintaining external and internal sustainability, reducing the country's vulnerability to external and natural shocks, and tackling long-term 
demographic pressure. These policy challenges were set against the backdrop of the 2009 debt sustainability analysis (DSA, IMF Country Report No. 10/64), the mining sector study recently completed by the authorities, and the preliminary results of a new population census, as well as recent program performance (Box 1). Potential risk of debt distress

\begin{tabular}{|c|c|}
\hline \multicolumn{2}{|c|}{ Box 1. Mali: Status of the 2008 Article IV Consultation Recommendations } \\
\hline $\begin{array}{l}\text { Advice } \\
\text { Fiscal Issues } \\
\text { Regain fiscal space over time to address } \\
\text { potential shocks. Improve tax and customs } \\
\text { administration to further broaden the } \\
\text { revenue base. Intensify efforts to reduce low } \\
\text { priority spending (including untargeted } \\
\text { transfers) and increase social spending. }\end{array}$ & $\begin{array}{l}\text { Prudent fiscal policies have been implemented, and } \\
\text { the } 2009 \text { basic fiscal deficit was lower than } \\
\text { programmed. However, slower revenue growth in } \\
\text { recent years has increased budget pressures and } \\
\text { reduced fiscal space. A new multi-donor PFM } \\
\text { reform plan to be implemented shortly includes } \\
\text { program budgeting reforms to improve expenditure } \\
\text { targeting and tax administration reforms. }\end{array}$ \\
\hline $\begin{array}{l}\text { Structural Reforms } \\
\text { - } \quad \text { Improve agriculture and work } \\
\text { toward food security. } \\
\text { Restructure and privatize public } \\
\text { enterprises, and reduce impediments } \\
\text { to private sector development. } \\
\text { Implement structural reforms } \\
\text { regarding privatization and } \\
\text { management of state enterprises. }\end{array}$ & $\begin{array}{l}\text { Widespread distribution of rain-fed rice seed; an } \\
\text { accelerated program to expand irrigation schemes; } \\
\text { and fertilizer subsidies to peasants have combined to } \\
\text { radically increase cereal production since } 2008 \text {. } \\
\text { Progress has been good in restructuring and } \\
\text { privatizing major public enterprises. However, the } \\
\text { environment for private sector development has } \\
\text { shown little improvement. }\end{array}$ \\
\hline $\begin{array}{l}\text { Financial Sector } \\
\text { Ensure that the banking sector is } \\
\text { stable and supports growth and } \\
\text { poverty reduction objectives. }\end{array}$ & $\begin{array}{l}\text { FSAP recommendations from } 2008 \text { have been } \\
\text { incorporated in Mali's financial sector strategy, } \\
\text { which is being implemented. }\end{array}$ \\
\hline $\begin{array}{l}\text { External Sector } \\
\text { - } \\
\text { Mali's Real Effective Exchange } \\
\text { Rate (REER) overvaluation is } \\
\text { modest but should be reduced } \\
\text { through reforms to enhance } \\
\text { productivity. }\end{array}$ & $\begin{array}{l}\text { No general public sector wage increases have been } \\
\text { announced since } 2007 \text {, helping to contain unit labor } \\
\text { costs. Some other reforms have been pursued, } \\
\text { though in piecemeal fashion. }\end{array}$ \\
\hline $\begin{array}{l}\text { Promoting Growth } \\
\text { - } \quad \text { Highlight policies that would make } \\
\text { Mali's economy more resilient to } \\
\text { natural hazards and adverse terms of } \\
\text { trade. Devise medium-term } \\
\text { economic policies to accelerate } \\
\text { growth and reduce poverty. }\end{array}$ & $\begin{array}{l}\text { Work is underway to revitalize the mining and } \\
\text { agricultural sectors and to improve Doing Business } \\
\text { indicators. Despite a greater focus on growth in } \\
\text { PRSP progress reports, policy measures have been } \\
\text { scarce outside these key sectors, and vulnerability } \\
\text { issues other than food have not been on the policy } \\
\text { agenda. }\end{array}$ \\
\hline
\end{tabular}


pointed to the need of prudent debt management policies; managing risks of external and natural shocks highlighted the need for sound contingent policies, budget flexibility and economic diversification; and boosting economic growth and reducing poverty called for more assertive development strategies and structural reforms to ensure development of the private sector and greater competitiveness.

\section{A. Managing Risk of Debt Distress}

\section{As a result of the HIPC Initiative and the Multilateral Debt Relief Initiative} (MDRI), as well as implementation of sound policies, Mali's risk of debt distress is low, but uncertainties regarding the mining sector's outlook might challenge that assessment. The 2009 DSA included a less favorable baseline growth in mineral exports than previous DSAs, and the potential for future debt distress hinged primarily on the outlook for the mining sector. The authorities have completed a gold sector study that confirms the prospects of a decline of the sector in the medium term on the basis of currently known reserves. The authorities expressed nevertheless confidence that Mali's prospects for future mineral development remained excellent (Box 2). For gold, the

\section{Box 2. Mining Sector: Macroeconomic Impact and Prospects}

Gold mining expanded in Mali for more than 20 years. Output rose from 5 tons a year in the mid-1990s to 25 tons in 2000 . The scaling up of industrial production allowed it to reach 60 tons in 2003, when Mali became the third largest gold producer in Africa and the ninth in the world. Annual output has oscillated around 54 tons since then.

Mali's economy now relies heavily on gold. In 2009, the sector accounted for 8 percent of GDP and more than 70 percent of gross merchandise exports. However, demand by the mines for local goods and services is limited, with many inputs sourced abroad. Moreover, the bulk of dividends accrues to non-residents and is therefore remitted abroad. More important is gold's contribution to government revenue, which has reached 20 percent in recent years.

Current proven reserves will likely be depleted in the medium term, but the scaling-up of exploration may allow production to continue. Current reserves should sustain production only for five to seven years, but the government is taking measures to accelerate exploration. It is now moving to reclaim unused exploration rights granted in the past to local entrepreneurs to reallocate them to international companies with more adequate technical and financial resources. The authorities also plan to expand geological surveys including with external bilateral technical assistance.

The diversification of mining beyond gold is also underway. Iron ore production with reserves estimated at 91 million tons, and phosphate production are slated to start later this year. A cement plant will open in 2011, with annual production of 1 million tons, while uranium mining is planned to begin in 2012. In addition, bauxite production is expected by 2016.and feasibility studies for other minerals, including manganese, copper, and nickel, are being undertaken. 
country has a promising geological structure, but intensified exploration is needed for the development of the underground mining activities that will eventually replace the current open-pit mines. The country has also interesting prospects for other minerals, with important development projects under discussion. The authorities recognized the risk that new production might not come on stream soon enough to offset the foreseeable decline in production from existing mining projects. They agreed that the sector needed close monitoring and consideration of new reforms with a view to facilitating exploration and enhancing non-gold mining prospects. To that end, they intend to present a draft for a new Mining Code to the National Assembly later this year.

\section{Pending confirmation of better prospects for the mining sector, prudent debt} management policies remain in order. The stress tests conducted under the DSA prepared by Bank and Fund staffs in late 2009 suggest some potential threats to external debt sustainability. Such threats preclude borrowing on non-concessional terms. Staff stressed the point that Mali should continue to finance its fiscal deficit primarily through external grants and concessional loans, and avoid recourse to nonconcessional mediumand long-term external debt, as well as costly domestic debt. The authorities shared this analysis and recognized the potential risks. They reaffirmed their current commitment to implementing prudent macroeconomic and financial policies, strengthening further their debt management capacity, and avoiding nonconcessional loans, despite the new flexibility in debt limits in Fund-supported programs.

\section{B. Managing Risk of External Shocks}

\section{The limited impact of the global recession on Mali belies the country's} susceptibility to exogenous shocks and its vulnerability to their effects. The dependence on rain-fed agriculture leaves the country open to both economic and humanitarian crises in the event of unfavorable rainfall or a repeat of the 2005 locust infestations. Indeed, the current food crisis in Niger and Chad has also touched Eastern Mali, where UN agencies say that some 250,000 people face food insecurity. Due to a heavy reliance on international assistance to face food crises, the authorities have usually maintained minimal budget outlays to respond to such situations. The country is also at risk of terms of trade shocks. Unfavorable movements in the world prices of oil products, cereals and cotton can have a significant impact on the economy and the population, as happened in 2008. The strength of gold prices since the onset of the global financial crisis has helped cushion Mali from the negative effects of the crisis, notably declines in non-privatization foreign direct investment and in private remittances, but these prices remain highly volatile.

\section{Ensuring a sustainable fiscal policy stance over the medium term remains a} prerequisite for addressing Mali's vulnerability to exogenous shocks. In this context, staff advocated that a basic fiscal deficit target of about 1 percent of GDP was sustainable inasmuch as it can be financed by projected net external budgetary support, does not imply 
a domestic financing requirement, and is concurrent with external debt sustainability. ${ }^{4}$ The authorities were in broad agreement with this underlying medium term fiscal path.

\section{For a given fiscal path of the deficit, a stronger revenue base can play an} important role in mitigating shocks. The staff encouraged the authorities to broaden the tax base and strengthen revenue administration. A key step would be to allow for greater flexibility in setting domestic petroleum product prices: between February 2009 and April 2010 , only 60 percent of the increase in border prices of oil products was passed through to pump prices, resulting in lost tax revenue of 0.3 percent of GDP on an annualized basis. The authorities agreed that it is important to broaden the tax base and pointed to their efforts to strengthen tax and customs administrations, as well as finalize a reform program by end-2010 to streamline and modernize the tax system. The authorities were less inclined than staff to view the rebound in oil prices as permanent and warranting additional action at this time.

\section{On the expenditure side, improved budget planning and execution can also} provide valuable room for maneuver in the face of unanticipated shocks. In particular, the staff underlined the importance of prudent budgeting, improved arbitrage between competing budgetary needs, and explicit contingency planning to tackle unforeseen events. The authorities stressed their track record of prudent macroeconomic policies, improved budget preparation, and rapid intervention to address unforeseen external shocks, such as in 2008. But they did not favor the introduction of explicit budgetary allocations for unforeseen events, arguing that the Malian budgetary system was flexible enough to address minor events through a reshuffle of allocations. In the case of major events, such precautionary budget allocations would not be sufficient and revised budget laws would be necessary.

\section{Managing Economic Growth Potential and Demographic Pressures}

\section{Mali's very high population growth poses a severe challenge for economic} development and poverty reduction. Recent economic growth of around 5 percent is insufficient to reduce poverty in a country with 3.6 percent population growth. Close to one half of Mali's population is now estimated to be under the age of 15 . With such a young age structure, Mali's population is expected to at least double in the next twenty-five years. This population surge translates into growing demand for public services and threatens to worsen the already high rate of youth unemployment. A recent World Bank study estimates that maintaining education standards in Mali would require more than a doubling of the

\footnotetext{
${ }^{4}$ The WAEMU targets a basic fiscal balance that is greater than or equal to zero. Under this criterion, total revenue, excluding grants, has to cover current expenditure and capital expenditure financed by domestic resources. Consequently, external budgetary support, net of amortization, cannot be used to support additional spending and has to be saved.
} 
number of teachers over the next five years. ${ }^{5}$ In the same vein, maintaining the current rate of 63 pupils per teacher would require creating each year about 2.5 times the number of new classrooms that have been completed in recent years. Similar issues arise for the provision of basic health and public sanitation services.

\section{A fast-growing population reinforces the need for deepening and accelerating} structural reforms to raise economic growth and create jobs. Mali's PRSP and recent progress reports point to an especially wide gap between low urban and high rural poverty, ${ }^{6}$ and rightly highlight higher economic growth as a necessary condition for poverty reduction (see Figure 2, Box 3, and Table 13 on progress towards the Millennium Development Goals).

Figure 2. Mali: Selected Millennium Development Goals for $2015^{1}$
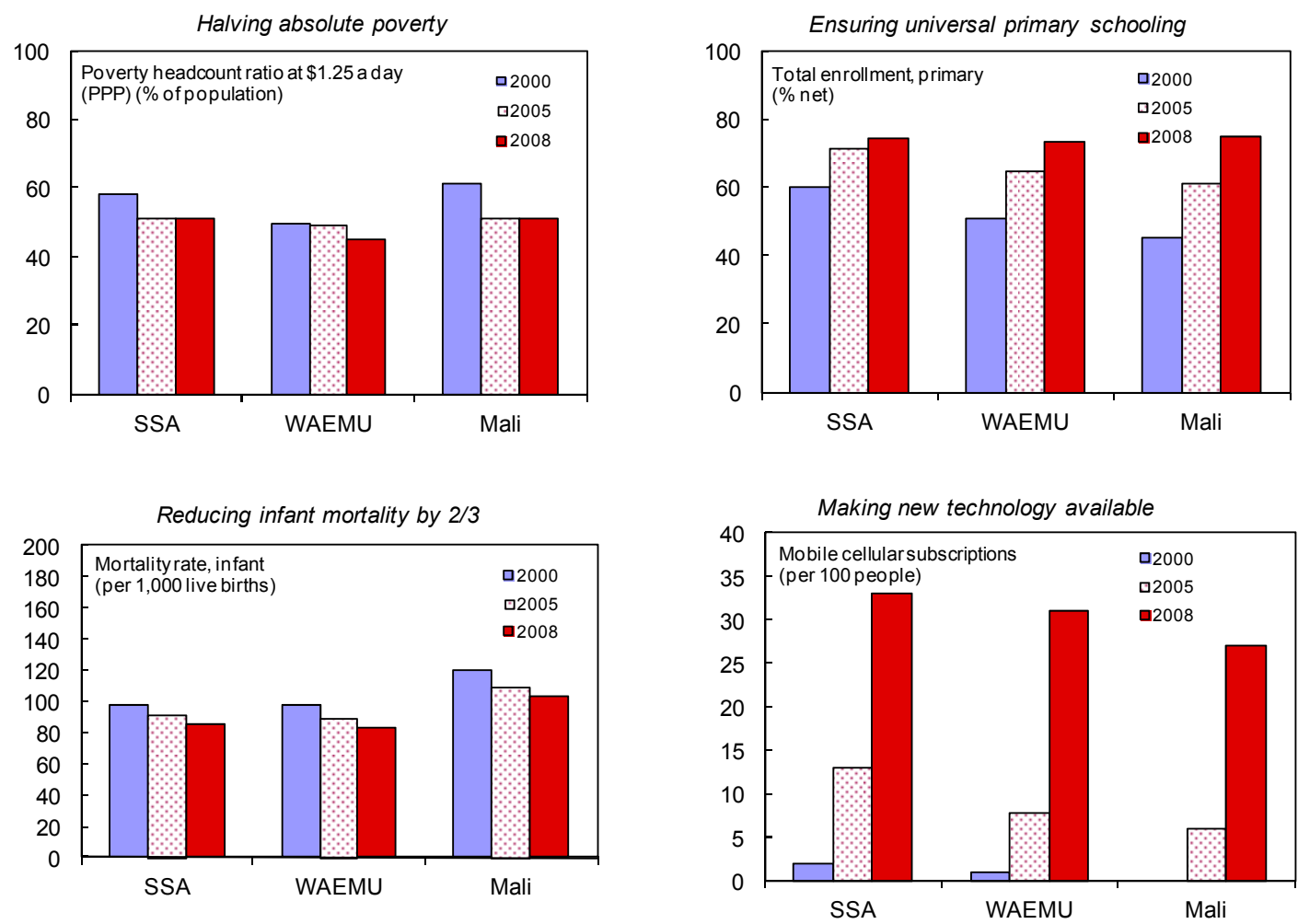

Source: The World Bank, Millennium Development Goals

${ }^{1}$ If data are not available, charts use data from the closest available year.

\footnotetext{
${ }^{5}$ « Mali-The Demographic Challenge », World Bank Report N 44459-ML, June 2009.

${ }^{6}$ Mali's progress report on the implementation of its PRSP in 2009 was reviewed in a workshop with donors and civil society organizations on June 7, 2010 and is being finalized. It can be reasonably expected to be submitted to the Board by end-December 2010.
} 
To this effect, the PRSP targets an annual average growth rate of 7 percent. Yet, this target remains ambitious in light of historical trends, and the new data on population growth would call for even higher economic growth rates. Staff stressed accordingly the need to buttress growth objectives by a stronger development strategy and comprehensive reforms. While noting that the results of the census and their impact on social sectors had yet to be confirmed, the authorities concurred with the need to refine their development strategy. They highlighted their commitment to strengthen current policies to support the development of the private sector and the agricultural sector, such as the Rice Initiative, targeted fertilizer subsidies, and support of the cotton sector. They stressed that a cornerstone of the strategy will remain the development of the agricultural sector. Various important projects are being implemented or under consideration in this context, including substantial external financing by development partners such as the Millennium Challenge Corporation and a multi-donor group for a $\$ 160$ million agricultural development program. Recent efforts to boost agricultural production, both through greater investment and through fertilizer subsidies that serve as income transfers, should also help temper the disparity between rural and urban areas.

\section{Box 3. The 2008 Progress Report on the Poverty Reduction Strategy (PRSP)}

On September 3, 2009, the Council of Ministers approved the 2008 PRSP progress report. The report noted the difficulties presented first by the food and fuel shocks and later by the global financial crisis, yet acknowledged that some of the measures taken to attenuate their impactnotably tax exemptions - were not well targeted and had a limited effect to protect the poor. The report recognizes the importance of the excellent 2008 harvest in avoiding stronger impacts from these shocks, and attributes much of the strong rise in production to the government's Rice Initiative. Going forward, the report makes a range of recommendations, including further efforts to develop social protection programs, provided that they are well targeted; measures to reduce Mali's vulnerability to external shocks; and acceleration of the statistics master plan.

\section{A particular concern for private sector-led growth is weak competitiveness. As} noted in the recent Article IV Consultation for the WAEMU area, up to the recent Euro depreciation, Mali's real effective exchange rate has risen by some 50 percent since the 1994 devaluation of the CFA franc. However, the standard exchange rate assessment points only to mild overvaluation (Box 3). Mali's lack of competitiveness stems primarily from structural causes that should be addressed by improving the business climate, diversifying the economic base, alleviating impediments to trade, and raising productivity. While important reforms have been effected under the current program, particularly with regard to the largest state-owned enterprises, the key impediments have diminished little, and Mali ranks $130^{\text {th }}$ of 133 countries in the World Economic Forum's most recent Global Competitiveness Report. In this context, the authorities indicated that they are implementing a result-oriented action plan adopted in early 2009 to improve business conditions and reduce operating costs of the private sector (Doing Business Indicators are reported in Table 14). 


\section{Box 4. Exchange Rate Assessment}

In addition to the work done recently for the 2010 WAEMU Consultation, two techniques from the standard toolkit - the macroeconomic balance and the external sustainability approacheshave been applied to assess the level of the CFA franc relative to its medium-term equilibrium level for Mali. While subject to significant statistical uncertainty and based on data preceding the recent weakening of the Euro, these additional approaches suggest that the CFA franc may be overvalued relative to the Malian economy by some 8 to 16 percent, broadly consistent with the results from the WAEMU consultation.

The macroeconomic balance approach suggests that the CFA franc is overvalued by about 8 percent relative to the level implied by Mali's medium-term fundamentals. This relies on an estimated norm for the current account deficit of about 5.5 percent of GDP, compared to an underlying projected deficit of 8.3 percent of GDP by 2015. Using an alternative specification that accounts for terms of trade and foreign aid composition, the norm for the current account deficit is somewhat smaller and the overvaluation of the CFAF franc is about 16 percent.

The external sustainability approach, which stabilizes net foreign assets, points to a smaller overvaluation of 9 percent. The resulting norm is about 3 percentage points of GDP below the projected level for current account deficit. Thus, with a nominal growth rate of 6 percent in Mali, the current account deficit necessary to stabilize net foreign assets at 60 percent of GDP is about 3 percent of GDP.

Mali: Exchange Rate Assessment

\begin{tabular}{|c|c|c|c|}
\hline Underlying current account & -8.3 & -8.3 & -8.3 \\
\hline Current account gap & 2.8 & 5.3 & 3.1 \\
\hline medium (assumes current a ccount elasticity of 0.34 ) & $(8.2)$ & $(15.6)$ & $(9.1)$ \\
\hline lower bound (assumes current account elasticity of 0.20$)^{5}$ & $(14.0)$ & $(26.5)$ & $(15.5)$ \\
\hline upper bound (assumes current account elasticity of 0.47 ) & $(6.0)$ & (11.3) & $(6.6)$ \\
\hline \multicolumn{4}{|c|}{$v$ A pplying co efficients drawn from IM F Occasional Paper 261(2008) } \\
\hline \multicolumn{4}{|c|}{ 2/ Appyling coefficients drawn from Christiansen et al (2009) including budgetary and project aid. } \\
\hline
\end{tabular}

\section{Tackling the vulnerabilities of and potential risks from the financial sector will contribute to a more stable macroeconomic environment and promote economic} growth. The authorities expressed satisfaction with the impact of the reduction of the stock of pending government payments on the quality of banks' portfolios, notwithstanding remaining weaknesses in treasury management and the end-2009 surge in pending bills (see Table 11 on financial soundness indicators). The authorities also expressed confidence that the important role played by regional banks in the Malian financial system did not constitute a significant source of additional risk, as local subsidiaries were sufficiently well 
capitalized and their claims on affiliated companies were limited. The expected consolidation in the banking system as a result of higher minimum capital requirements had not yet taken place, and staff urged close attention to weaknesses that might emerge in this process. The authorities considered that the creation of a financial stability department at the central bank would largely fill the need in this regard.

\section{The recommendations of the 2008 FSAP have been incorporated into the} authorities' own financial sector development strategy (FSDS), adopted by the Cabinet in July 2008. The action plan derived from the FSDS is being implemented and significant progress has been achieved in the areas of bank restructuring and public debt management. The authorities and staff agreed on the need to keep the momentum of reforms in these areas and implement other recommendations, including those to strengthen bank supervision.

\section{Other Issues}

\section{Mali's statistical base is adequate for effective surveillance, and efforts are} under way to strengthen capacity (Statistical Issues are summarized in the Informational Annex). Staff reviewed progress in implementing the GFS 2001 methodology. In particular, it discussed ways to strengthen the monitoring of public companies and prospects to widen the coverage of public finance statistics from the central government to the nonfinancial public sector. Particular emphasis was placed on strengthening these statistics, as well as balance of payments data, in the context of the ECF arrangement.

\section{Against a backdrop of security issues and reported drug trafficking in the} North of the country, Mali is making progress in addressing the deficiencies of its framework for Anti-Money Laundering and Combating the Finance of Terrorism (AML/CFT). A 2008 report had found Mali's regime in an embryonic state with legislative and preventative measures being assessed as deficient, and Mali was partially compliant or non-compliant with 46 out of 49 of the recommendations. The follow-up report presented in November 2009 to the Inter Governmental Action Group against Money Laundering in West Africa (GIABA) pointed out some progress in AML/CFT, in particular with regard to the criminalization of financing of terrorism. Essential structures of the AML/CFT mechanism have been established and made operational, including the Financial Intelligence Unit (CENTIF) and the Planning and Statistics Unit. Additional actions are envisaged to build up the efficacy of the framework, such as the creation of an inter-ministerial committee and the elaboration of a national strategy to coordinate action.

\section{Further trade liberalization, notably in the event of an Economic Partnership} Agreement (EPA) with the European Union (EU), could help to strengthen Mali's competitiveness. Trade policy issues are normally handled on a regional basis at the WAEMU level. For the EU, however, negotiations are being conducted by ECOWAS, with assistance from the WAEMU commission, and Mali has not been pursuing a separate 
interim bilateral agreement. The Malian authorities are concerned over possible revenue losses from an EPA, and they support the regional position that accompanying measuresincluding financial assistance to offset the impact of liberalization under the EPA - should be in place before an agreement is signed.

\section{The most recent safeguards assessment of the BCEAO was completed on}

March 1, 2010. The 2010 update assessment found that the BCEAO continues to have controls in place at the operational level. The overall governance framework should nonetheless be strengthened by the addition of an audit committee to ensure that the Board of Directors exercises appropriate oversight over the control structure, including the audit mechanisms and financial statements. Efforts to implement fully the International Financial Reporting Standards reporting framework should also be pursued.

\section{STAfF Appraisal}

29. Despite the global financial and economic crisis, the implementation of the government's economic and financial program in 2009 was broadly satisfactory. Growth was sustained at 4.5 percent, inflation reduced to 2.2 percent, and the balance of payments improved markedly. Mali also benefited from exceptional revenue linked to the privatization of the telecom parastatal SOTELMA and the SDR allocations of the IMF.

\section{The overall basic budget deficit, on a commitment basis, was lower than} expected, but the targeted reduction in pending bills was delayed until end-March 2010. The Ministry of Economy and Finance is taking corrective measures to address this issue and prevent the recurrence of payment arrears, including on VAT credits. A continued focus on strengthening treasury management is central to the authorities' PFM objectives.

31. The implementation of structural reforms continued to make good progress in 2009, notably with regards to the state enterprises and the strengthening of public finances. SOTELMA was successfully privatized; the housing bank BHM is being effectively restructured; and the reform of the cotton sector, including the privatization of the parastatal CMDT, is moving ahead. Work also continues apace in the strengthening of public financial management, and staff looks forward to the finalization of the new reform program in this area.

32. The 2010 economic outlook remains positive. The implementation of a prudent fiscal stimulus package, to be financed by part of SOTELMA's privatization revenue and cast in a revised budget law, will buttress economic growth in a stable macroeconomic context. In this regard, the staff welcomes the authorities' commitments to continue implementing prudent policies and maintain an underlying fiscal adjustment process with a view to preserving long term sustainability of public finances. The revised budget law also reflects, in line with previous commitments, recent government decisions on agricultural input subsidies and support to the cotton sector. Staff urges the authorities to monitor 
carefully budget execution and realize the necessary savings that will ensure respect of the program targets for the basic fiscal deficits.

33. Mali's exchange regime and real exchange rate remain broadly appropriate, and the country is at low risk of debt distress. Nevertheless, the country faces major challenges in remaining internationally competitive, and reforms aimed at reducing the cost of doing business and at improving the provision of financial services need greater attention. Mali's rapid population growth, and the need to find jobs for a swelling population, further increase the urgency of measures to raise the growth rate.

34. Mali continues to be highly vulnerable to external shocks. Improving the country's capacity to respond to such shocks, including by maintaining prudent fiscal policies, would make the country more resilient. Moreover, higher growth and progress in reducing rural poverty would also help reduce these vulnerabilities.

35. The provision of data is broadly adequate for Fund surveillance. However, staff encourages the authorities to pursue their efforts to address, including with Fund support, limitations and deficiencies in their data compilation and reporting systems.

36. Based on program performance to date and the authorities' commitments to program implementation, staff recommends completion of the fourth review of the ECF arrangement.

37. It is expected that the next Article IV consultation with Mali will take place in accordance with the July 15, 2002 Executive Board decision on consultation cycles. 
Table 1. Mali: Selected Economic and Financial Indicators, 2008-12

\begin{tabular}{|c|c|c|c|c|c|c|c|}
\hline & \multirow{2}{*}{$\begin{array}{r}2008 \\
\text { Est. }\end{array}$} & \multicolumn{2}{|c|}{2009} & \multicolumn{2}{|c|}{2010} & \multirow{2}{*}{$\begin{array}{r}2011 \\
\text { Proj. }\end{array}$} & \multirow{2}{*}{$\begin{array}{r}2012 \\
\text { Proj. }\end{array}$} \\
\hline & & $\begin{array}{r}\text { Prog. } \\
\text { 3rd Review }\end{array}$ & Est. & $\begin{array}{r}\text { Prog. } \\
\text { 3rd Review }\end{array}$ & $\begin{array}{l}\text { Rev. } \\
\text { Prog. }\end{array}$ & & \\
\hline & \multicolumn{7}{|c|}{ (Annual percentage change) } \\
\hline \multicolumn{8}{|l|}{ National income and prices } \\
\hline Real GDP & 4.9 & 4.3 & 4.5 & 4.8 & 5.1 & 5.3 & 5.8 \\
\hline GDP deflator & 8.8 & 4.3 & 3.6 & 2.6 & 3.6 & 3.0 & 2.4 \\
\hline Consumer price inflation (average) & 9.1 & 2.2 & 2.2 & 1.2 & 2.1 & 2.6 & 2.8 \\
\hline \multicolumn{8}{|l|}{ External sector (percent change) } \\
\hline Terms of trade (deterioration -) & -1.9 & 27.2 & 23.7 & -8.4 & 6.6 & 4.3 & -1.7 \\
\hline Real effective exchange rate (depreciation -) & 8.0 & $\ldots$ & 0.3 & $\ldots$ & $\ldots$ & $\ldots$ & $\ldots$ \\
\hline \multicolumn{8}{|l|}{ Money and credit (contribution to broad money growth) } \\
\hline Credit to the government & -3.2 & -7.6 & -13.9 & 5.3 & 10.4 & 5.0 & 2.1 \\
\hline Credit to the economy & 5.2 & 5.6 & 7.2 & 6.9 & 5.7 & 5.4 & 6.7 \\
\hline Broad money (M2) & 0.5 & 15.3 & 16.0 & 10.5 & 16.7 & 9.4 & 8.2 \\
\hline & \multicolumn{7}{|c|}{ (In percent of GDP, unless otherwise stated) } \\
\hline \multicolumn{8}{|l|}{ Investment and saving } \\
\hline Gross domestic investment & 20.7 & 18.4 & 18.2 & 19.7 & 20.0 & 21.0 & 21.5 \\
\hline Of which: government & 5.7 & 6.8 & 6.7 & 7.2 & 7.5 & 7.6 & 7.2 \\
\hline Gross national savings & 7.8 & 12.2 & 8.6 & 11.7 & 12.1 & 11.8 & 12.4 \\
\hline Of which : government & 1.8 & 1.2 & 0.8 & 0.5 & 1.5 & 1.5 & 1.6 \\
\hline Gross domestic savings & 6.2 & 10.7 & 7.0 & 9.9 & 10.3 & 12.1 & 13.1 \\
\hline \multicolumn{8}{|l|}{ Central government finance } \\
\hline Revenue & 15.5 & 16.6 & 17.1 & 16.9 & 16.9 & 17.0 & 17.2 \\
\hline Grants & 3.4 & 4.9 & 4.1 & 3.8 & 3.9 & 3.8 & 3.8 \\
\hline Total expenditure and net lending & 21.2 & 24.7 & 24.1 & 24.6 & 25.5 & 24.8 & 24.6 \\
\hline Overall balance (payment order basis, excluding grants) & -5.6 & -8.0 & -6.9 & -7.7 & -8.5 & -7.8 & -7.3 \\
\hline Basic fiscal balance ${ }^{1}$ & -1.0 & -1.8 & -1.4 & -1.6 & -2.4 & -2.0 & -1.5 \\
\hline Underlying basic fiscal balance ${ }^{2}$ & -1.0 & -1.4 & -0.8 & -1.1 & -1.1 & -1.0 & -1.0 \\
\hline \multicolumn{8}{|l|}{ External sector } \\
\hline Current external balance, including official transfers & -12.9 & -6.1 & -9.6 & -8.0 & -7.9 & -9.1 & -9.1 \\
\hline Current external balance, excluding official transfers & -14.1 & -8.2 & -11.9 & -10.2 & -10.2 & -11.2 & -11.2 \\
\hline Exports of goods and services & 28.5 & 27.5 & 26.0 & 26.8 & 28.9 & 30.6 & 31.3 \\
\hline Imports of goods and services & -43.1 & -35.2 & -37.2 & -36.6 & -38.5 & -39.5 & -39.7 \\
\hline Debt service to exports of goods and services & 4.0 & 4.0 & 4.2 & 4.0 & 3.7 & 2.3 & 2.3 \\
\hline External debt (end of period) & 19.1 & 20.2 & 19.3 & 22.2 & 24.2 & 26.1 & 27.9 \\
\hline \multicolumn{8}{|l|}{ Memorandum items: } \\
\hline Nominal GDP (CFAF billions) & 3,913 & 4,248 & 4,232 & 4,564 & 4,609 & 5,005 & 5,414 \\
\hline Overall balance of payments (US\$ millions) & -10.3 & 419.6 & 448.0 & -90.9 & -44.1 & -41.0 & -38.7 \\
\hline Money market interest rate in percent (end of period) & 6.8 & $\ldots$ & $\ldots$ & $\ldots$ & $\ldots$ & $\ldots$ & $\ldots$ \\
\hline \multicolumn{8}{|l|}{ Gross international reserves (US\$ millions) } \\
\hline Central Bank of West African States (BCEAO) & 10,721 & $\ldots$ & 13,631 & $\ldots$ & $\ldots$ & $\ldots$ & ... \\
\hline in percent of broad money & 55.0 & $\ldots$ & 58.7 & $\ldots$ & $\ldots$ & $\ldots$ & ... \\
\hline in months of imports & 6.1 & $\ldots$ & 6.9 & $\ldots$ & $\ldots$ & $\ldots$ & $\ldots$ \\
\hline BCEAO Mali (imputed $)^{3}$ & 1,033 & 1,637 & 1,602 & 1,575 & 1,389 & 1,343 & 1,287 \\
\hline in percent of broad money & 48.6 & 64.4 & 60.6 & 56.3 & 51.5 & 45.8 & 40.8 \\
\hline US\$ exchange rate (end of period) & 481.5 & 464.5 & 449.3 & $\ldots$ & $\ldots$ & $\ldots$ & $\ldots$ \\
\hline
\end{tabular}

Sources: Malian authorities; and IMF staff estimates and projections.

\footnotetext{
${ }^{1}$ Revenue (excluding grants) less total expenditure excluding foreign financed investment projects and HIPC Initiative spending.

${ }^{2}$ Basic fiscal balance excluding spending financed by privatization revenue.

${ }^{3}$ For 2009 , reflects new SDR allocation and privatization receipts of SOTELMA.
} 


\begin{tabular}{|c|c|c|c|c|c|c|c|c|c|c|c|c|}
\hline & \multicolumn{3}{|c|}{ March } & \multicolumn{3}{|c|}{ June } & \multicolumn{3}{|c|}{ Sept. } & \multicolumn{3}{|c|}{ Dec. } \\
\hline & $\begin{array}{r}\text { Indic. } \\
\text { Targets }\end{array}$ & Adjusted & Actual & $\begin{array}{r}\text { Rev. Perf. } \\
\text { Criteria } \\
\end{array}$ & Adjusted & $\overline{\text { Actual }}$ & $\begin{array}{r}\text { Rev. Ind. } \\
\text { Targets } \\
\end{array}$ & Adjusted & Actual & $\begin{array}{r}\text { Rev. } \\
\text { Perf. Crit } \\
\end{array}$ & Adjusted & Actual \\
\hline Quantitative performance criteria ${ }^{1}$ & \multicolumn{12}{|c|}{ (CFAF billions) } \\
\hline Net domestic financing of the Government (ceiling) ${ }^{2}$ & 10.0 & 11.8 & $13.1^{7}$ & 45.0 & 40.1 & -5.0 & 50.0 & 32.9 & -4.3 & 49.4 & 46.0 & 26.6 \\
\hline Of which: Bank and market financing ${ }^{2}$ & 15.0 & 16.8 & $22.3^{7}$ & 80.0 & 75.1 & 55.1 & 90.0 & 72.9 & -136.9 & -101.5 & -104.9 & -105.9 \\
\hline Cumulative increase in external payments arrears (ceiling) ${ }^{3}$ & 0.0 & 0.0 & 0.0 & 0.0 & 0.0 & 0.0 & 0.0 & 0.0 & 0.0 & 0.0 & 0.0 & 0.0 \\
\hline $\begin{array}{l}\text { New external borrowing at terms of one year or more contracted c } \\
\text { guaranteed by the government on nonconcessional terms }\end{array}$ & 0.0 & 0.0 & $17.5^{8}$ & 0.0 & 0.0 & 0.0 & 0.0 & 0.0 & 0.0 & 0.0 & 0.0 & 0.0 \\
\hline \multicolumn{13}{|l|}{ New short-term external credits (less than one year) } \\
\hline contracted or guaranteed by the government (ceiling) ${ }^{3}$ & 0.0 & 0.0 & 0.0 & 0.0 & 0.0 & 0.0 & 0.0 & 0.0 & 0.0 & 0.0 & 0.0 & 0.0 \\
\hline Net tax revenue & 140.0 & 140.0 & 143.5 & 290.0 & 290.0 & 319.9 & 430.0 & 430.0 & 451.3 & 603.0 & 603.0 & 624.3 \\
\hline \multicolumn{13}{|l|}{ Financial indicators (floors) } \\
\hline Basic fiscal balance & -10.0 & -10.0 & 17.1 & -20.0 & -20.0 & 66.1 & -40.0 & -40.0 & 23.7 & -78.0 & -78.0 & -58.1 \\
\hline Underlying basic fiscal balance ${ }^{5}$ & & & & & & & & & & -62.0 & -62.0 & -32.7 \\
\hline \multicolumn{13}{|l|}{ Memorandum items: } \\
\hline External budgetary assistance during the year ${ }^{16}$ & 20.0 & $\ldots$ & 6.4 & 38.5 & $\ldots$ & 13.0 & 52.0 & $\ldots$ & 53.2 & 92.0 & $\ldots$ & 91.6 \\
\hline $\begin{array}{l}\text { HIPC Initiative debt relief }{ }^{1} \\
\text { Expenditure financed with HIPC Initiative resources } \\
\text { Balance of HIPC Initiative resources }\end{array}$ & 1.0 & $\ldots$ & 1.8 & 6.3 & $\ldots$ & 9.4 & 8.1 & $\ldots$ & 10.8 & 11.2 & $\ldots$ & 13.0 \\
\hline
\end{tabular}

${ }^{1}$ Cumulative figures from the beginning of each year. Noncontinuous performance criteria at end-March and end-September 2009 are quantitative benchmarks. See technical memorandum of understandings for definitions.

${ }^{2}$ These quantitative targets are before payment of VAT credits in arrears. The revised targets for the end-June, end-September, and end-December 2009 reflect the recapitalization of the Housing Bank of Mali (BHM) for CFAF 19.1 billion in May 2009

and net projected reductions of the payment float by CFAF 45 billion at end-June and end-September 2009, and CFAF 30 billion at end-December 2009 (the program includes an adjustor for any deviations from the targets on the reduction of the payment float).

${ }^{3}$ These performance criteria will be monitored on a continuous basis.

${ }^{4}$ Grant component equal to or higher than 35 percent.

${ }^{5}$ Excluding expenditures financed with funds from the privatization of SOTELMA

${ }^{6}$ General budget support only.

${ }^{7}$ The nonobservance of the quantitative indicators for net domestic financing and bank and market financing results from a bond issue that was initiated in December 2008 but effective on January 2, 2009, leading to a downward correction of CFAF 12.3 billion at end-December 2008 and an upward revision of the same amount at end-March 2009 in market financing.

${ }^{8}$ Part of two CFAF syndicated loans that were signed in April and May 2009 for a total of CFAF 38 billion for the payment of VAT credit arrears and that involved non-Malian banks in the WAEMU and CEMAC CFA franc zones; subsequently resold to Malian banks.

\section{CInternational Monetary Fund. Not for Redistribution}


Table 3. Mali: Quantitative Performance Criteria and Indicative Targets for $2010^{1}$

\begin{tabular}{|c|c|c|c|c|c|c|c|c|c|}
\hline & \multicolumn{9}{|c|}{2010} \\
\hline & \multicolumn{3}{|c|}{ March } & \multicolumn{2}{|c|}{ June } & \multicolumn{2}{|c|}{ Sep. } & \multicolumn{2}{|c|}{ Dec. } \\
\hline & $\begin{array}{r}\text { Indic. } \\
\text { Targets }\end{array}$ & $\begin{array}{r}\text { Adjusted } \\
\text { Targets } \\
\end{array}$ & Prel. & $\begin{array}{r}\text { Perf. } \\
\text { Criteria } \\
\end{array}$ & $\begin{array}{r}\text { Rev. Perf. } \\
\text { Criteria }\end{array}$ & $\begin{array}{r}\text { Indic. } \\
\text { Targets }\end{array}$ & $\begin{array}{r}\text { Rev. Ind. } \\
\text { Targets } \\
\end{array}$ & $\begin{array}{r}\text { Indic. } \\
\text { Targets } \\
\end{array}$ & $\begin{array}{r}\text { Perf. } \\
\text { Criteria } \\
\end{array}$ \\
\hline Quantitative performance criteria ${ }^{1}$ & \multicolumn{9}{|c|}{ (CFAF billions) } \\
\hline Net domestic financing of the Government (ceiling) ${ }^{2}$ & 0.0 & 52.4 & 19.3 & 0.0 & 79.8 & 10.0 & 113.7 & 30.0 & 127.0 \\
\hline Of which: Bank and market financing ${ }^{2}$ & 0.0 & 52.4 & 46.9 & 0.0 & 99.3 & 10.0 & 128.7 & 30.0 & 138.6 \\
\hline Cumulative increase in external payments arrears (ceiling) ${ }^{3}$ & 0.0 & 0.0 & 0.0 & 0.0 & 0.0 & 0.0 & 0.0 & 0.0 & 0.0 \\
\hline \multicolumn{10}{|l|}{ New external borrowing at terms of one year or more contracted or } \\
\hline guaranteed by the government on nonconcessional terms ${ }^{3,4}$ & 0.0 & 0.0 & 0.0 & 0.0 & 0.0 & 0.0 & 0.0 & 0.0 & 0.0 \\
\hline \multicolumn{10}{|l|}{ New short-term external credits (less than one year) } \\
\hline contracted or guaranteed by the government (ceiling) & 0.0 & 0.0 & 0.0 & 0.0 & 0.0 & 0.0 & 0.0 & 0.0 & 0.0 \\
\hline Net tax revenue & 130.0 & 130.0 & 154.8 & 300.0 & 304.7 & 470.0 & 490.9 & 670.0 & 677.1 \\
\hline \multicolumn{10}{|l|}{ Financial indicators (floors) ${ }^{1}$} \\
\hline Basic fiscal balance & -30.0 & -30.0 & 23.3 & -40.0 & -52.8 & -70.0 & -92.4 & -75.0 & -111.5 \\
\hline Basic fiscal balance, adjusted ${ }^{5}$ & 10.0 & 10.0 & 23.3 & 0.0 & -38.8 & -20.0 & -48.4 & -50.0 & -51.7 \\
\hline Priority spending & $\ldots$ & $\ldots$ & $\ldots$ & $\ldots$ & 117.0 & $\ldots$ & 175.0 & $\ldots$ & 235.0 \\
\hline \multicolumn{10}{|l|}{ Memorandum items: } \\
\hline External budgetary assistance during the year ${ }^{1}$ & 20.0 & 24.0 & 15.5 & 50.0 & 68.3 & 80.0 & 96.4 & 125.3 & 144.1 \\
\hline HIPC Initiative debt relief ${ }^{1}$ & 3.1 & 1.3 & 1.3 & 6.2 & 6.9 & 9.3 & 9.7 & 12.4 & 12.4 \\
\hline
\end{tabular}

1. Cumulative figures from the beginning of each year. Noncontinuous performance criteria at end-March and end-September 2010 are quantitative benchmarks. See technical memorandum of understandings for definitions.

${ }^{2}$ These performance criteria and benchmarks are subject to adjustors for shorffalls of external budgetary assistance et over/under performance regarding the targeted reduction of pending bills and VAT credits.

The reductions of pending bills are 2.0, 43.7, 48.7 and 49.1 billion of CFAF at end-March, June, September and December 2010, respectively. A reduction of VAT credits by 29.0 billion of CFAF is projected for end-December 2010.

${ }^{3}$ These performance criteria will be monitored on a continuous basis.

${ }^{4}$ Grant component equal to or higher than 35 percent.

${ }^{5}$ Excluding expenditures financed with funds from the privatization of SOTELMA. 
Table 4. Mali: Structural Benchmarks for the Third and Fourth Reviews Under the ECF Program

For end-September 2009 (in the context of the 3rd program review)

1 Put in place the tax center for medium-sized enterprises (CIME) and start up its activities.

2 Prepare a government cash flow plan consistent with budget nomenclature (section, economic code) to facilitate (i) quarterly monitoring of budget execution in terms of commitment, validation, payment authorization, and payment of expenditure, and (ii) better alignment of budget execution with available resources.

3 Regarding monitoring of the cotton sector and in consultation with the IMF, prepare a monthly financial plan for the 2009/10 crop season of the financial operations (revenue, commitments, payment, debt, amounts unpaid) of the various participants in the sector(producers, CMDT, suppliers, banks, the government).

4 Regarding government support for the agricultural sector and preparation of the 2010 budget, put in place a dedicated, targeted input subsidization system for grain and cotton crops, including modalities for implementation, followup, and assessment.
Strengthen revenue mobilization.

Observed at endNovember 2009

Strengthen public financial management, budget execution, and treasury management.
Observed at endSeptember 2009
Improve governmence and transparency in Observed at endthe cotton sector with the view to ensuring September 2009 smooth cottn campaign in 2009-2010 and limit budgetary risks.
Increase effectiveness and transparency of agricultural policy, prevent open-ended budgetary contributions and ensure monitoring and evaluation of subsidies.

Observed at endSeptember 2009

\section{For end-December 2009 (in the context of the 4th program review)}

1 On the basis of the evaluation of the budgetary payment float at end-March 2008 by the Auditor General and the evaluation of the payment float at end-March 2009 by the Controller General's Office and the Inspectorate General of Finance, put in place a system to monitor budgetary float supported by improvements in the Treasury's accounting, cash flow management, and information systems, in consultation with IMF staff.

2 By government decision, adopt a strategy and timeframe for government divestment of the Banque de l'Habitat du Mali (BHM).

3 Finalize the government study on the macroeconomic impact of the gold mining sector (balance of payments, growth, employment, budget) and its medium-term prospects.

4 In conjunction with the BCEAO, prepare (i) an exhaustive inventory of the bank accounts taken into account in the net government position, and (ii) an appropriate methodology for recording movements on these accounts, based on an accepted classification (such as projects, correspondents, etc.) in the government flow of funds table (TOFE).
Improve transparency, measurability and management of domestic debt, and prevent occurance of domestic payment arrears.

Increase confidence in and resilience of Observed at endthe banking system, and avoid more costly December 2009 rescue packages.

To help policy and decision making in the context of a declining sector (known reserves are equivalent to 10 years of exploitation).

Improve public finance statistics.

Observed at endDecember 2009
Not observed at endDecember 2009, as a result of decision to implement new public accounting software; monitoring of pending bills continues to be done through the expenditure chain.

Observed at endDecember 2009 
Table 5. Mali: Structural Benchmarks for the Fifth and Sixth Reviews Under the ECF Program

Measures

Macroeconomic rationale

\section{For end-June 2010 (in the context of the fifth program review)}

1 Implement the new expenditure management software PRED5.

2 Introduce new reporting on the financial operations of the State (the "TOFE" table) which conforms to best international practices, including for the presentation of domestic financing.

3 Create an interministerial committee for treasury management planning under the authority of the Minister of Economy and Finance, with a permanent technical secretariat provided by Treasury.

4 Prepare a draft policy paper on the role of the State in the cotton sector after the privatization of the CMDT.
To improve budgetary management.

To strengthen government statistics and reporting.

To improve treasury management and its coordination with budgetary management.

To set the business environment in the cotton sector in a post-privatization of the state monopsony CMDT.

For end-December 2010 (in the context of the sixth program review)

1 Implement a system for the management and timely payment of Value Added Tax (VAT) credits to eligible companies.

2 Produce an evaluation of restructuring of the Housing Bank of Mali (BHM), including the use of State funds transferred to the $\mathrm{BHM}$ in the first half of 2010 to relaunch its lending activities.

3 Elaborate a program for the reform of the tax system, aiming at a greater mobilization of revenue while ensuring greater rationalization and modernization of the tax laws, including through reconsideration of tax exemptions.

4 Implement the new public accounting software in the Treasury with the necessary links to the budget application software to ensure monitoring of spending from commitment to payment, including the stock of pending bills.
To prevent accumulation of VAT credit arrears and ensure neutrality of VAT on exports.

To ensure that the BHM is effectively on a recovery track.

To simplify and make the tax system more buoyant, while implementing regional directives.

To ensure improved recording and reporting of financial operations of the State. 
Table 6. Mali: National Accounts, 2008-12

\begin{tabular}{|c|c|c|c|c|c|c|c|}
\hline & \multirow{2}{*}{$\begin{array}{r}2008 \\
\text { Est. }\end{array}$} & \multicolumn{2}{|c|}{2009} & \multicolumn{2}{|c|}{2010} & \multirow{2}{*}{$\begin{array}{r}2011 \\
\text { Proj. }\end{array}$} & \multirow{2}{*}{$\begin{array}{r}2012 \\
\text { Proj. }\end{array}$} \\
\hline & & $\begin{array}{r}\text { Prog. } \\
\text { 3rd review } \\
\end{array}$ & Est. & $\begin{array}{r}\text { Prog. } \\
\text { 3rd review }\end{array}$ & $\begin{array}{l}\text { Rev. } \\
\text { Prog. }\end{array}$ & & \\
\hline & \multicolumn{7}{|c|}{ (Annual percentage change, at constant prices) } \\
\hline Primary sector & 13.2 & 5.9 & 5.6 & 5.3 & 5.3 & 5.3 & 5.8 \\
\hline Agriculture & 20.2 & 6.7 & 6.4 & 5.9 & 5.9 & 5.5 & 5.5 \\
\hline Food crops, excluding rice & 14.4 & 6.1 & 5.6 & 4.0 & 4.0 & 5.0 & 5.0 \\
\hline Rice & 48.5 & 6.0 & 6.0 & 8.0 & 8.0 & 5.0 & 5.0 \\
\hline Industrial agriculture, excluding cotton & 22.0 & 9.0 & 9.0 & 9.5 & 9.5 & 5.0 & 5.0 \\
\hline Cotton & -16.8 & 17.3 & 16.8 & 15.0 & 15.0 & 15.0 & 15.0 \\
\hline Livestock & 4.0 & 4.2 & 4.2 & 4.3 & 4.3 & 4.0 & 4.0 \\
\hline Fishing and forestry & 3.7 & 5.3 & 5.3 & 4.6 & 4.6 & 4.3 & 4.0 \\
\hline Secondary sector & -4.6 & 3.4 & 3.5 & 4.7 & 4.5 & 8.0 & 8.6 \\
\hline Mining & -6.4 & -0.6 & 1.5 & 2.6 & -1.7 & 11.0 & 12.2 \\
\hline Industry & -14.4 & 4.4 & 0.9 & 3.4 & 7.4 & 5.6 & 6.0 \\
\hline Agrobusiness & -20.0 & 7.4 & 8.0 & 2.0 & 8.4 & 5.5 & 6.0 \\
\hline Textile & -34.0 & -1.5 & 5.0 & 1.6 & 15.0 & 3.0 & 3.5 \\
\hline Others & 16.2 & 5.0 & -9.2 & 6.0 & 0.5 & 8.0 & 8.0 \\
\hline Energy & 10.0 & 7.8 & 10.0 & 8.8 & 11.0 & 8.0 & 7.0 \\
\hline Construction and public works & 4.5 & 6.0 & 6.0 & 7.0 & 7.0 & 6.5 & 7.0 \\
\hline Tertiary sector & 4.1 & 3.3 & 3.5 & 4.1 & 5.2 & 4.3 & 5.2 \\
\hline Transportation and telecommunications & 10.0 & 3.0 & 1.9 & 5.0 & 5.0 & 4.5 & 6.5 \\
\hline Trade & 4.4 & 3.5 & 4.5 & 4.5 & 7.4 & 5.0 & 6.0 \\
\hline Financial services & 2.0 & 3.5 & 3.5 & 3.5 & 3.5 & 5.0 & 5.0 \\
\hline Other nonfinancial services & 1.0 & 5.1 & 5.1 & 4.7 & 4.7 & 5.0 & 4.0 \\
\hline Public administration & 1.2 & 2.0 & 2.0 & 1.9 & 1.9 & 2.3 & 3.5 \\
\hline "Branche fictive" & 5.5 & 4.0 & 4.0 & 3.0 & 3.0 & 8.0 & 10.0 \\
\hline GDP ( factor cost) & 5.5 & 4.3 & 4.3 & 4.7 & 5.1 & 5.3 & 5.8 \\
\hline Indirect taxes & -2.0 & 4.0 & 5.9 & 6.0 & 5.0 & 6.0 & 6.0 \\
\hline GDP (market prices) & 4.9 & 4.3 & 4.5 & 4.8 & 5.1 & 5.3 & 5.8 \\
\hline \multirow[t]{2}{*}{ Nonmining real GDP } & 5.9 & 4.7 & 4.7 & 4.9 & 5.6 & 5.0 & 5.3 \\
\hline & \multicolumn{7}{|c|}{ (Percentage of GDP, unless otherwise indicated) } \\
\hline \multicolumn{8}{|l|}{ Aggregate demand } \\
\hline Consumption & 93.8 & 89.3 & 93.0 & 90.1 & 89.6 & 87.9 & 86.9 \\
\hline Private consumption & 81.2 & 75.5 & 79.5 & 76.3 & 75.8 & 74.2 & 73.1 \\
\hline Public consumption & 12.6 & 13.8 & 13.5 & 13.8 & 13.8 & 13.7 & 13.8 \\
\hline Gross investment & 20.7 & 18.4 & 18.2 & 19.7 & 20.0 & 21.0 & 21.5 \\
\hline Government & 5.7 & 6.8 & 6.7 & 7.2 & 7.5 & 7.6 & 7.2 \\
\hline Non-government & 15.1 & 11.5 & 11.5 & 12.5 & 12.5 & 13.3 & 14.3 \\
\hline Net investment & 11.5 & 9.5 & 9.5 & 10.5 & 10.5 & 11.5 & 12.5 \\
\hline Changes in inventories & 3.6 & 2.0 & 2.0 & 2.0 & 2.0 & 1.8 & 1.8 \\
\hline Net foreign balance & -14.5 & -7.7 & -11.2 & -9.8 & -9.6 & -8.8 & -8.4 \\
\hline Gross national saving & 7.8 & 12.2 & 8.6 & 11.7 & 12.1 & 11.8 & 12.4 \\
\hline Of which: domestic saving & 6.2 & 10.7 & 7.0 & 9.9 & 10.4 & 12.1 & 13.1 \\
\hline \multicolumn{8}{|l|}{ Memorandum items: } \\
\hline External current account balance ${ }^{1}$ & -12.9 & -6.1 & -9.6 & -8.0 & -7.9 & -9.1 & -9.1 \\
\hline Nominal GDP (CFAF billions) & 3,913 & 4,248 & 4,232 & 4,564 & 4,609 & 5,005 & 5,414 \\
\hline GDP deflator (annual percent change) & 8.8 & 4.3 & 3.6 & 2.6 & 3.6 & 3.0 & 2.4 \\
\hline
\end{tabular}

Sources: Malian authorities; and IMF staff estimates and projections.

${ }^{1}$ Including official transfers. 
Table 7. Mali: Balance of Payments, 2008-12 ${ }^{1}$

\begin{tabular}{|c|c|c|c|c|c|c|c|}
\hline & \multirow{2}{*}{$\begin{array}{r}2008 \\
\text { Est. }\end{array}$} & \multicolumn{2}{|c|}{2009} & \multicolumn{2}{|c|}{2010} & \multirow{2}{*}{$\begin{array}{l}2011 \\
\text { Proj. }\end{array}$} & \multirow{2}{*}{$\begin{array}{l}2012 \\
\text { Proj. }\end{array}$} \\
\hline & & $\begin{array}{l}\text { Prog. } \\
\text { 3rd review }\end{array}$ & Est. & $\begin{array}{l}\text { Prog. } \\
\text { 3rd review }\end{array}$ & $\begin{array}{l}\text { Rev. } \\
\text { Prog. }\end{array}$ & & \\
\hline & \multicolumn{7}{|c|}{ (CFAF billions) } \\
\hline \multicolumn{8}{|l|}{ Current account balance } \\
\hline Excluding official transfers & -552.3 & -349.0 & -504.3 & -463.4 & -469.2 & -561.5 & -604.6 \\
\hline Including official transfers & -504.8 & -259.9 & -406.8 & -363.4 & -365.2 & -457.5 & -492.1 \\
\hline Trade balance & -313.3 & -76.1 & -220.9 & -174.0 & -152.8 & -87.3 & -59.5 \\
\hline Exports, f.o.b. & 913.5 & 978.4 & 911.3 & $1,010.3$ & $1,128.4$ & $1,320.6$ & $1,473.5$ \\
\hline Cotton fiber & 65.6 & 60.9 & 60.6 & 55.2 & 80.2 & 91.9 & 104.6 \\
\hline Gold & 645.9 & 737.2 & 641.1 & 752.3 & 817.6 & 983.9 & $1,109.1$ \\
\hline Other & 202.0 & 180.3 & 209.6 & 202.9 & 230.6 & 244.7 & 259.8 \\
\hline Imports, f.o.b. & $-1,226.8$ & $-1,054.5$ & $-1,132.2$ & $-1,184.4$ & $-1,281.2$ & $-1,407.9$ & $-1,533.1$ \\
\hline Petroleum products & -261.2 & -182.0 & -175.7 & -230.1 & -236.4 & -265.4 & -297.2 \\
\hline Foodstuffs & -153.0 & -143.8 & -141.1 & -147.7 & -139.2 & -139.1 & -143.4 \\
\hline Other & -812.6 & -728.7 & -815.4 & -806.6 & -905.6 & $-1,003.5$ & $-1,092.5$ \\
\hline Services (net) & -255.2 & -250.2 & -253.1 & -272.8 & -291.6 & -355.5 & -397.9 \\
\hline Credit & 203.4 & 191.5 & 189.5 & 211.2 & 202.1 & 211.4 & 220.8 \\
\hline Debit & -458.7 & -441.7 & -442.6 & -484.0 & -493.7 & -566.9 & -618.7 \\
\hline Of which : freight and insurance & -267.0 & -255.4 & -248.5 & -286.9 & -281.2 & -324.9 & -353.8 \\
\hline Income (net) & -140.0 & -155.4 & -155.4 & -160.3 & -160.3 & -265.9 & -306.4 \\
\hline Of which: interest due on public debt & -16.2 & -12.5 & -12.4 & -14.8 & -14.8 & -10.0 & -11.3 \\
\hline Transfers (net) & 203.7 & 221.8 & 222.6 & 243.7 & 239.6 & 251.2 & 271.7 \\
\hline Private transfers (net) & 156.2 & 132.7 & 125.1 & 143.6 & 135.6 & 147.2 & 159.3 \\
\hline Official transfers (net) & 47.5 & 89.1 & 97.5 & 100.0 & 104.0 & 104.0 & 112.5 \\
\hline Of which: budgetary grants & 25.0 & 46.6 & 51.9 & 54.4 & 54.4 & 50.1 & 54.1 \\
\hline Capital and financial account & 449.4 & 460.3 & 511.9 & 320.9 & 343.5 & 436.8 & 472.5 \\
\hline Capital account (net) & 147.3 & 158.2 & 160.0 & 140.6 & 169.8 & 184.6 & 200.4 \\
\hline Of which: project grants & 109.2 & 140.1 & 119.7 & 120.7 & 127.4 & 138.6 & 150.6 \\
\hline Financial account & 302.1 & 302.1 & 351.9 & 180.3 & 173.7 & 252.3 & 272.2 \\
\hline Private (net) ${ }^{2}$ & 230.5 & 125.5 & 188.9 & 41.7 & 22.8 & 88.6 & 94.5 \\
\hline Direct investment (net) & 80.5 & 206.3 & 228.4 & 60.7 & 52.5 & 73.7 & 72.6 \\
\hline Portfolio investment private (net) & 3.4 & 4.4 & 4.4 & 4.4 & 4.6 & 5.0 & 5.4 \\
\hline Other private capital flows & 146.6 & -85.2 & -44.0 & -23.5 & -34.4 & 10.0 & 16.4 \\
\hline Official (net) & 71.6 & 176.6 & 163.0 & 138.7 & 151.0 & 163.6 & 177.7 \\
\hline Disbursements & 99.9 & 158.0 & 144.0 & 172.6 & 184.9 & 189.1 & 204.3 \\
\hline Budgetary & 29.1 & 45.9 & 39.7 & 29.9 & 42.2 & 35.0 & 37.9 \\
\hline Project related & 70.8 & 112.1 & 104.3 & 142.7 & 142.6 & 154.0 & 166.4 \\
\hline Monetary authority & 0.0 & 52.5 & 52.5 & 0.0 & 0.0 & 0.0 & 0.0 \\
\hline Amortization due on public debt & -28.3 & -33.9 & -33.5 & -33.9 & -33.9 & -25.4 & -26.6 \\
\hline Errors and omissions & 50.9 & 0.0 & 106.0 & 0.0 & -0.4 & -0.5 & -0.5 \\
\hline Overall balance & -4.6 & 200.4 & 211.0 & -42.3 & -22.1 & -21.2 & -20.1 \\
\hline Financing & 4.6 & -200.4 & -211.0 & 42.3 & 22.1 & 21.2 & 20.1 \\
\hline Foreign assets (net) & -6.3 & -211.9 & -224.0 & 30.0 & 9.7 & 21.2 & 20.1 \\
\hline Of which: IMF (net) & 13.4 & 1.5 & 1.5 & 4.3 & 4.4 & 1.1 & -0.9 \\
\hline HIPC Initiative assistance & 10.9 & 11.5 & 13.0 & 12.4 & 12.4 & 0.0 & 0.0 \\
\hline Financing gap & 0.0 & 0.0 & 0.0 & 0.0 & 0.0 & 0.0 & 0.0 \\
\hline $\begin{array}{l}\text { Memorandum items: } \\
\text { External trade }\end{array}$ & \multicolumn{7}{|c|}{ (Annual percentage changes, unless otherwise specified) } \\
\hline Export volume index & -1.3 & -0.8 & -7.1 & 3.7 & 3.9 & 9.1 & 10.7 \\
\hline Import volume index & 12.5 & 11.1 & 6.3 & 3.4 & 1.1 & 12.7 & 8.7 \\
\hline Export unit value & 26.2 & 10.1 & 7.4 & -0.4 & 19.2 & 7.3 & 0.8 \\
\hline Import unit value & 28.7 & -13.4 & -13.1 & 8.6 & 11.9 & 2.9 & 2.5 \\
\hline Terms of trade & -1.9 & 27.2 & 23.7 & -8.4 & 6.6 & 4.3 & -1.7 \\
\hline
\end{tabular}

Sources: Malian authorities; and IMF staff estimates and projections.

1 Presented according to the Balance of Payments Manual (5th edition ); 2006-2010 data after adjustment for MDRI.

2 Reflects mainly investments in the gold sector and, in 2009, the privatization of SOTELMA; includes short-term capital flows. 
Table 7. Mali: Balance of Payments, $2008-12{ }^{1}$ (concluded)

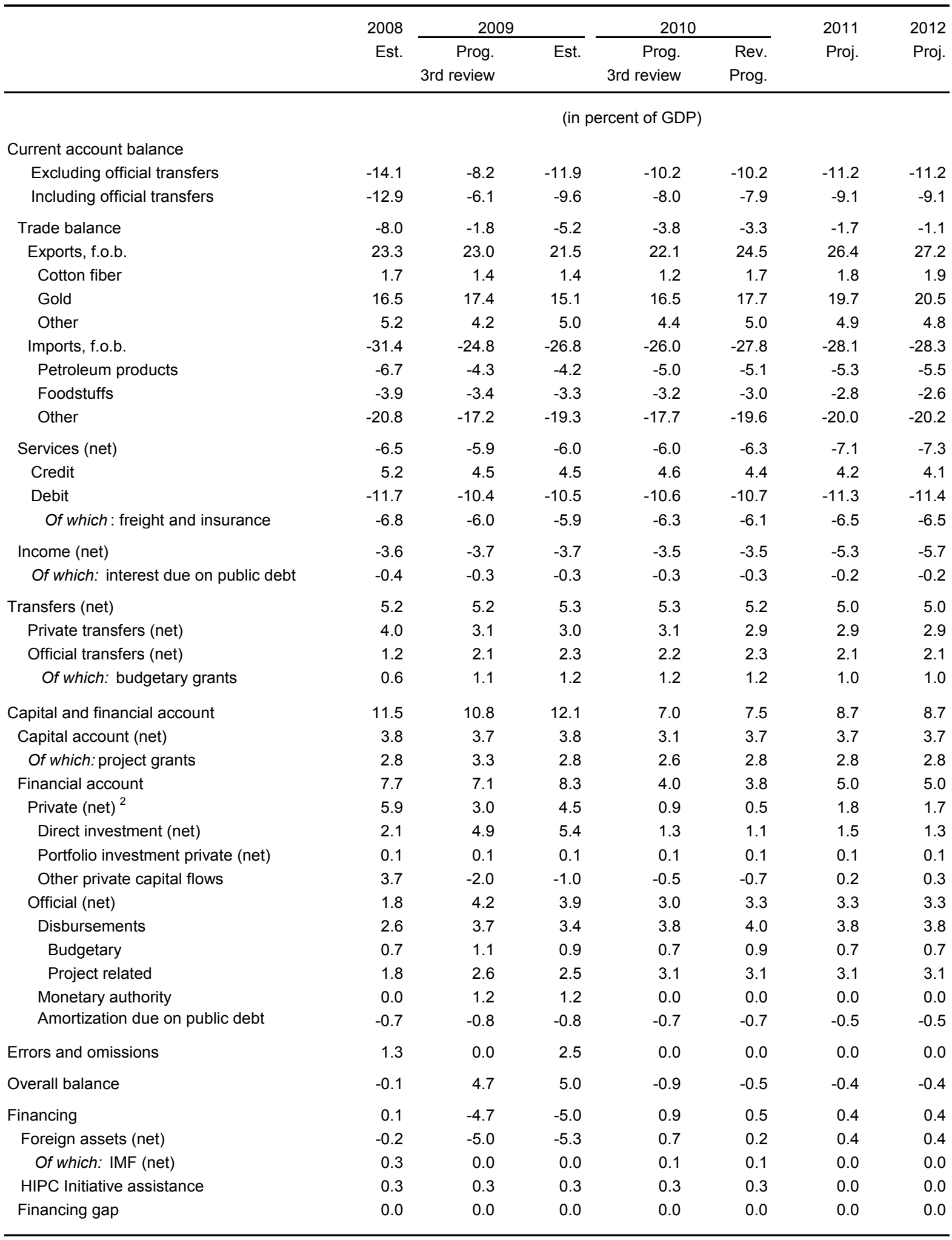

Sources: Malian authorities; and IMF staff estimates and projections.

${ }^{1}$ Presented according to the Balance of Payments Manual (5th edition ); 2006-2010 data after adjustment for MDRI.

${ }^{2}$ Reflects mainly investments in the gold sector and, in 2009, the privatization of SOTELMA; includes short-term capital flows. 
Table 8. Mali: Central Government Consolidated Financial Operations, 2008-12

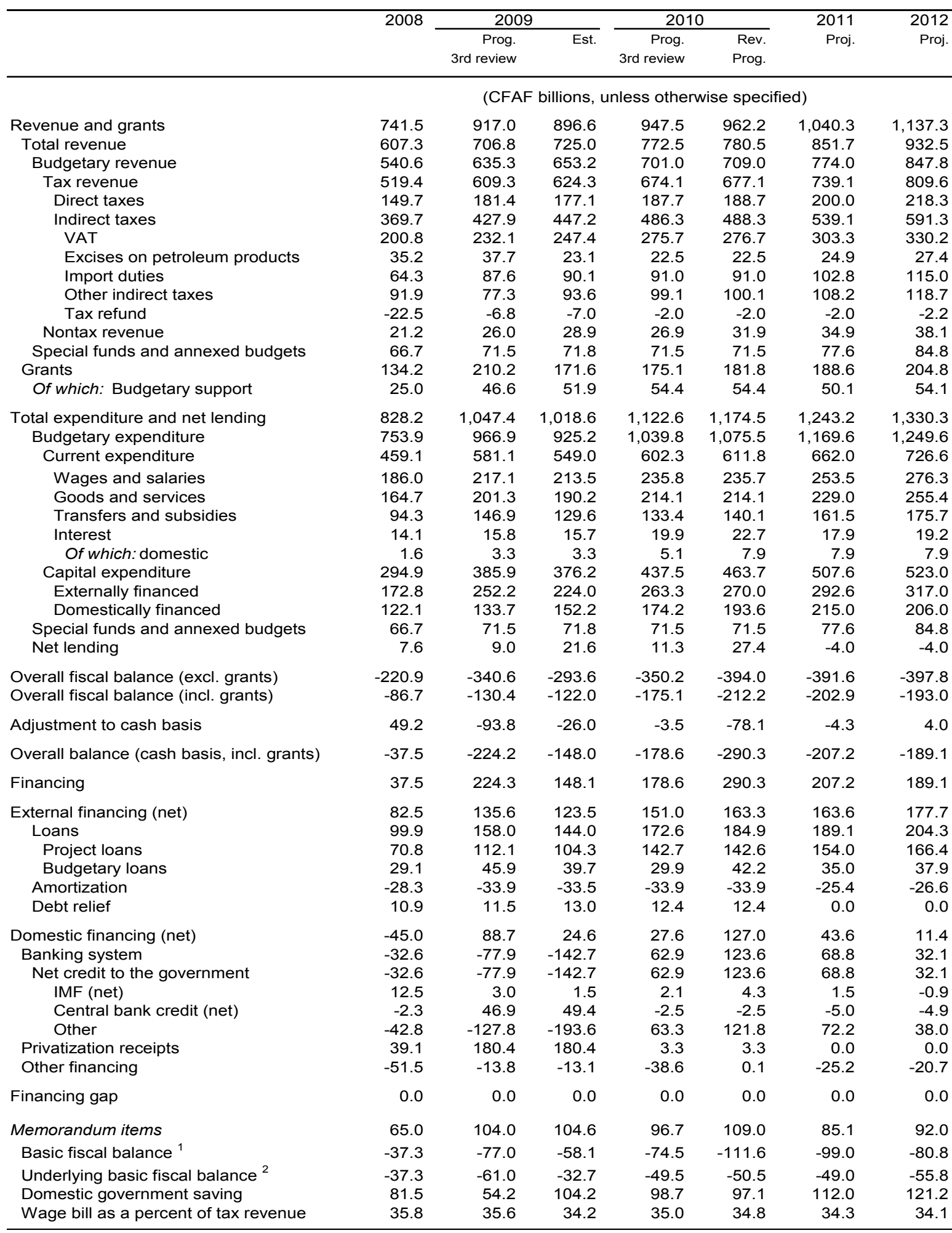

Sources: Ministry of Finance; and IMF staff estimates and projections.

${ }^{1}$ Total revenue less current noninterest spending and net lending, excluding grants, externally financed capital expenditure and HIPC-financed spending.

${ }^{2}$ Basic fiscal balance excluding spending financed by privatization revenue. 
Table 8. Mali: Central Government Consolidated Financial Operations, 2008-12 (concluded)

\begin{tabular}{|c|c|c|c|c|c|c|c|}
\hline & \multirow[t]{2}{*}{2008} & \multicolumn{2}{|c|}{2009} & \multicolumn{2}{|c|}{2010} & \multirow{2}{*}{$\begin{array}{r}2011 \\
\text { Proj. }\end{array}$} & \multirow{2}{*}{$\begin{array}{r}2012 \\
\text { Proj. }\end{array}$} \\
\hline & & $\begin{array}{r}\text { Prog. } \\
\text { 3rd review }\end{array}$ & Est. & $\begin{array}{r}\text { Prog. } \\
\text { 3rd review }\end{array}$ & $\begin{array}{l}\text { Rev. } \\
\text { Prog. }\end{array}$ & & \\
\hline & \multicolumn{7}{|c|}{ (in percent of GDP) } \\
\hline Revenue and grants & 19.0 & 21.6 & 21.2 & 20.8 & 20.9 & 20.8 & 21.0 \\
\hline Total revenue & 15.5 & 16.6 & 17.1 & 16.9 & 16.9 & 17.0 & 17.2 \\
\hline Budgetary revenue & 13.8 & 15.0 & 15.4 & 15.4 & 15.4 & 15.5 & 15.7 \\
\hline Tax revenue & 13.3 & 14.3 & 14.8 & 14.8 & 14.7 & 14.8 & 15.0 \\
\hline Direct taxes & 3.8 & 4.3 & 4.2 & 4.1 & 4.1 & 4.0 & 4.0 \\
\hline Indirect taxes & 9.4 & 10.1 & 10.6 & 10.7 & 10.6 & 10.8 & 10.9 \\
\hline VAT & 5.1 & 5.5 & 5.8 & 6.0 & 6.0 & 6.1 & 6.1 \\
\hline Excises on petroleum products & 0.9 & 0.9 & 0.5 & 0.5 & 0.5 & 0.5 & 0.5 \\
\hline Import duties & 1.6 & 2.1 & 2.1 & 2.0 & 2.0 & 2.1 & 2.1 \\
\hline Other indirect taxes & 2.3 & 1.8 & 2.2 & 2.2 & 2.2 & 2.2 & 2.2 \\
\hline Tax refund & -0.6 & -0.2 & -0.2 & 0.0 & 0.0 & 0.0 & 0.0 \\
\hline Nontax revenue & 0.5 & 0.6 & 0.7 & 0.6 & 0.7 & 0.7 & 0.7 \\
\hline Special funds and annexed budgets & 1.7 & 1.7 & 1.7 & 1.6 & 1.6 & 1.6 & 1.6 \\
\hline Grants & 3.4 & 4.9 & 4.1 & 3.8 & 3.9 & 3.8 & 3.8 \\
\hline Of which: Budgetary support & 0.6 & 1.1 & 1.2 & 1.2 & 1.2 & 1.0 & 1.0 \\
\hline Total expenditure and net lending & 21.2 & 24.7 & 24.1 & 24.6 & 25.5 & 24.8 & 24.6 \\
\hline Budgetary expenditure & 19.3 & 22.8 & 21.9 & 22.8 & 23.3 & 23.4 & 23.1 \\
\hline Current expenditure & 11.7 & 13.7 & 13.0 & 13.2 & 13.3 & 13.2 & 13.4 \\
\hline Wages and salaries & 4.8 & 5.1 & 5.0 & 5.2 & 5.1 & 5.1 & 5.1 \\
\hline Goods and services & 4.2 & 4.7 & 4.5 & 4.7 & 4.6 & 4.6 & 4.7 \\
\hline Transfers and subsidies & 2.4 & 3.5 & 3.1 & 2.9 & 3.0 & 3.2 & 3.2 \\
\hline Interest & 0.4 & 0.4 & 0.4 & 0.4 & 0.5 & 0.4 & 0.4 \\
\hline Of which: domestic & 0.0 & 0.1 & 0.1 & 0.1 & 0.2 & 0.2 & 0.1 \\
\hline Capital expenditure & 7.5 & 9.1 & 8.9 & 9.6 & 10.1 & 10.1 & 9.7 \\
\hline Externally financed & 4.4 & 5.9 & 5.3 & 5.8 & 5.9 & 5.8 & 5.9 \\
\hline Domestically financed & 3.1 & 3.1 & 3.6 & 3.8 & 4.2 & 4.3 & 3.8 \\
\hline Special funds and annexed budgets & 1.7 & 1.7 & 1.7 & 1.6 & 1.6 & 1.6 & 1.6 \\
\hline Net lending & 0.2 & 0.2 & 0.5 & 0.2 & 0.6 & -0.1 & -0.1 \\
\hline Overall fiscal balance (excl. grants) & -5.6 & -8.0 & -6.9 & -7.7 & -8.5 & -7.8 & -7.3 \\
\hline Overall fiscal balance (incl. grants) & -2.2 & -3.1 & -2.9 & -3.8 & -4.6 & -4.1 & -3.6 \\
\hline Adjustment to cash basis & 1.3 & -2.2 & -0.6 & -0.1 & -1.7 & -0.1 & 0.1 \\
\hline Overall balance (cash basis, incl. grants) & -1.0 & -5.3 & -3.5 & -3.9 & -6.3 & -4.1 & -3.5 \\
\hline Financing & 1.0 & 5.3 & 3.5 & 3.9 & 6.3 & 4.1 & 3.5 \\
\hline External financing (net) & 2.1 & 3.2 & 2.9 & 3.3 & 3.5 & 3.3 & 3.3 \\
\hline Loans & 2.6 & 3.7 & 3.4 & 3.8 & 4.0 & 3.8 & 3.8 \\
\hline Project loans & 1.8 & 2.6 & 2.5 & 3.1 & 3.1 & 3.1 & 3.1 \\
\hline Budgetary loans & 0.7 & 1.1 & 0.9 & 0.7 & 0.9 & 0.7 & 0.7 \\
\hline Amortization & -0.7 & -0.8 & -0.8 & -0.7 & -0.7 & -0.5 & -0.5 \\
\hline Debt relief & 0.3 & 0.3 & 0.3 & 0.3 & 0.3 & 0.0 & 0.0 \\
\hline Domestic financing (net) & -1.2 & 2.1 & 0.6 & 0.6 & 2.8 & 0.9 & 0.2 \\
\hline Banking system & -0.8 & -1.8 & -3.4 & 1.4 & 2.7 & 1.4 & 0.6 \\
\hline Net credit to the government & -0.8 & -1.8 & -3.4 & 1.4 & 2.7 & 1.4 & 0.6 \\
\hline IMF (net) & 0.3 & 0.1 & 0.0 & 0.0 & 0.1 & 0.0 & 0.0 \\
\hline Central bank credit, net & -0.1 & 1.1 & 1.2 & -0.1 & -0.1 & -0.1 & -0.1 \\
\hline Other & -1.1 & -3.0 & -4.6 & 1.4 & 2.6 & 1.4 & 0.7 \\
\hline Privatization receipts & 1.0 & 4.2 & 4.3 & 0.1 & 0.1 & 0.0 & 0.0 \\
\hline Other financing & -1.3 & -0.3 & -0.3 & -0.8 & 0.0 & -0.5 & -0.4 \\
\hline Financing gap & 0.0 & 0.0 & 0.0 & 0.0 & 0.0 & 0.0 & 0.0 \\
\hline \multicolumn{8}{|l|}{ Memorandum items } \\
\hline Basic fiscal balance $^{1}$ & -1.0 & -1.8 & -1.4 & -1.6 & -2.4 & -2.0 & -1.5 \\
\hline Underlying basic fiscal balance ${ }^{2}$ & -1.0 & -1.4 & -0.8 & -1.1 & -1.1 & -1.0 & -1.0 \\
\hline Domestic government saving & 2.1 & 1.3 & 2.5 & 2.2 & 2.1 & 2.2 & 2.2 \\
\hline
\end{tabular}

Sources: Ministry of Finance; and IMF staff estimates and projections.

'Total revenue less current noninterest spending and net lending, excluding grants, externally financed capital expenditures, and HIPC-financed spending.

${ }^{2}$ Basic fiscal balance excluding spending financed by privatization revenue. 
Table 9. Mali: WAEMU Convergence Criteria, 2006-12

\begin{tabular}{|c|c|c|c|c|c|c|c|c|}
\hline & Criterion & 2006 & 2007 & 2008 & 2009 & $\begin{array}{c}2010 \\
\text { Proj. }\end{array}$ & $\begin{array}{c}2011 \\
\text { Proj. }\end{array}$ & $\begin{array}{r}2012 \\
\text { Proj. }\end{array}$ \\
\hline & \multicolumn{8}{|c|}{ (Ratios in percent, unless otherwise indicated) } \\
\hline \multicolumn{9}{|l|}{ Primary criteria } \\
\hline Basic fiscal balance / GDP & $>=0$ & 0.3 & -0.9 & -1.0 & -1.4 & -2.4 & -2.0 & -1.5 \\
\hline Inflation (annual average percentage change) & $<=3$ & 1.5 & 1.5 & 9.1 & 2.2 & 2.1 & 2.6 & 2.8 \\
\hline Total nominal debt / GDP & $<=70$ & 39.9 & 19.4 & 21.6 & 21.4 & 25.7 & 27.0 & 28.5 \\
\hline Domestic arrears accumulation (CFAF billions) & $<=0$ & 0.0 & 0.0 & 145.7 & -87.6 & 0.0 & 0.0 & 0.0 \\
\hline External arrears accumulation (CFAF billions) & $<=0$ & 0.0 & 0.0 & 0.0 & 0.0 & 0.0 & 0.0 & 0.0 \\
\hline \multicolumn{9}{|l|}{ Secondary criteria } \\
\hline Wages / fiscal revenue & $<=35$ & 30.9 & 33.4 & 35.8 & 34.2 & 34.8 & 34.3 & 34.1 \\
\hline Domestically financed investment / fiscal revenue & $>=20$ & 22.2 & 31.7 & 22.6 & 23.3 & 27.3 & 27.8 & 24.3 \\
\hline Current account deficit, excl. current official transfers / & $<=5$ & -6.7 & -9.5 & -14.1 & -11.9 & -10.2 & -11.2 & -11.2 \\
\hline Tax revenue / GDP & $>=17$ & 14.9 & 14.2 & 13.3 & 14.8 & 14.7 & 14.8 & 15.0 \\
\hline
\end{tabular}

Sources: Malian authorities; and IMF staff estimates and projections. 
Table 10. Mali: Monetary Survey, 2008-12

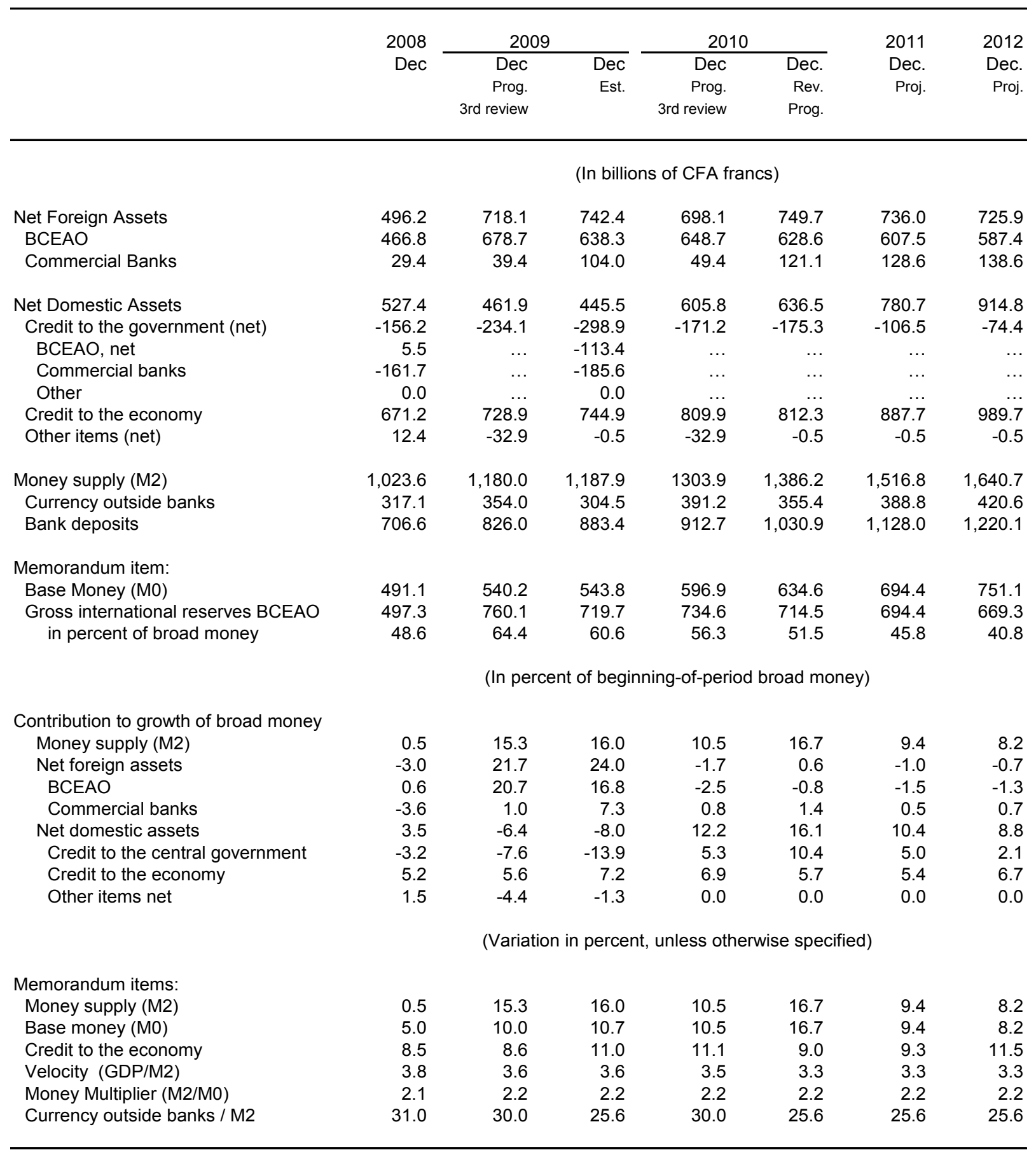

Sources: BCEAO; and Fund staff estimates and projections. 
Table 11. Mali: Financial Soundness Indicators for the Banking Sector, 2002-09 ${ }^{1 /}$

$200220032004200520062007 \quad 2008 \quad 2009$

Prel.

\section{Capital Adequacy}

Capital (net worth) in percent of assets

$\begin{array}{rrrrrrrr}10.0 & 9.7 & 7.4 & 9.7 & 9.2 & 7.2 & 7.4 & 8.5 \\ & & & & & & & \\ 19.5 & 15.6 & 19.6 & 30.2 & 25.0 & 25.1 & 25.3 & 22.0 \\ & & & & & & & \\ 9.6 & 7.3 & 9.9 & 16.3 & 12.6 & 10.7 & 9.3 & 9.1 \\ 56.4 & 57.5 & 55.0 & 55.0 & 57.0 & 65.5 & 66.9 & 64.4 \\ & & & & & & & \\ & & & & & & & \\ 14.6 & 13.1 & -28.3 & 14.3 & 13.5 & -13.9 & 15.9 & 20.8 \\ 7.7 & 7.6 & -22.6 & 8.7 & 8.7 & -12.1 & 13.3 & 13.2 \\ 6.0 & 6.4 & 6.2 & 6.5 & 7.0 & 7.3 & 7.9 & 9.0\end{array}$

\section{Asset composition and quality}

Nonperforming loans in percent of total loans

Nonperforming loans net of provisions in percent of total credits net of provisions

Provisions as percent of nonperforming loans

\section{Earnings and profitability}

Net profit (before tax) in percent of net income

Return on equity

Global margin (yield on loans minus cost of capital)

Source: BCEAO, and IMF staff estimates.

$1 /$ Ratios calculated on the basis of average stocks of the period. 
Table 12. Mali: Medium Term Projections, 2008-15

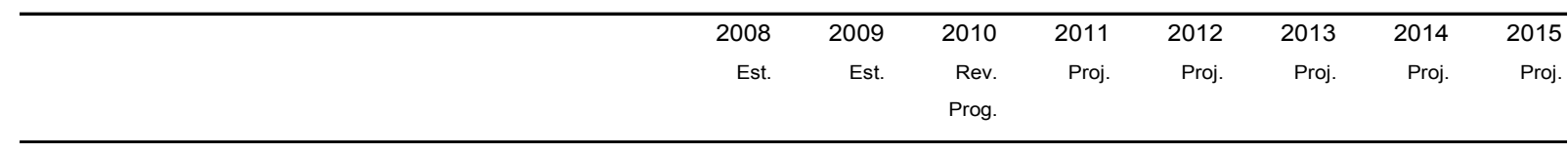

(Annual percentage change)

National income and prices

Real GDP

GDP deflator

Consumer price inflation (average)

External sector (percent change)

Terms of trade (deterioration -)

Real effective exchange rate (depreciation -)

Money and credit (contribution to broad money growth)

Credit to the government

Credit to the economy

Broad money (M2)

Investment and saving

Gross domestic investment

Of which: government

Gross national savings

Of which: government

Gross domestic savings

Central government finance

Revenue

Grants

Total expenditure and net lending

Overall balance (payment order basis, excluding grants)

Basic fiscal balance ${ }^{1}$

Underlying basic fiscal balance ${ }^{2}$

External sector

Current external balance, including official transfers

Current external balance, excluding official transfers

Exports of goods and services

Imports of goods and services

Debt service to exports of goods and services

External debt (end of period)

Memorandum items:

Nominal GDP (CFAF billions)

Overall balance of payments (US\$ millions)

Money market interest rate in percent (end of period)

Gross international reserves (US\$ millions)

Central Bank of African States (BCEAO)

in percent of broad money

in months of imports

BCEAO Mali (imputed) ${ }^{3}$

in percent of broad money

US\$ exchange rate (end of period)

$\begin{array}{rrrrrrrr}4.9 & 4.5 & 5.1 & 5.3 & 5.8 & 5.2 & 5.0 & 4.5 \\ 8.8 & 3.6 & 3.6 & 3.0 & 2.4 & 2.6 & 2.6 & 2.5 \\ 9.1 & 2.2 & 2.1 & 2.6 & 2.8 & 2.8 & 2.8 & 3.4 \\ & & & & & & & \\ -1.9 & 23.7 & 6.6 & 4.3 & -1.7 & -0.9 & -0.6 & -2.9 \\ 8.0 & 0.3 & \ldots & \ldots & \ldots & \ldots & \ldots & \ldots \\ & & & & & & & \\ & & & & & & & \\ -3.2 & -13.9 & 10.4 & 5.0 & 2.1 & 0.1 & -0.5 & -0.5 \\ 5.2 & 7.2 & 5.7 & 5.4 & 6.7 & 7.1 & 5.5 & 4.5 \\ 0.5 & 16.0 & 16.7 & 9.4 & 8.2 & 7.9 & 7.7 & 7.0\end{array}$

(In percent of GDP, unless otherwise stated)

$\begin{array}{rrrrrrrr}20.7 & 18.2 & 20.0 & 21.0 & 21.5 & 22.2 & 23.1 & 24.5 \\ 5.7 & 6.7 & 7.5 & 7.6 & 7.2 & 7.0 & 7.0 & 7.4 \\ 7.8 & 8.6 & 12.1 & 11.8 & 12.4 & 13.6 & 15.0 & 16.2 \\ 1.8 & 0.8 & 1.5 & 1.5 & 1.6 & 1.9 & 1.8 & 1.7 \\ 6.2 & 7.0 & 10.3 & 12.1 & 13.1 & 14.2 & 15.6 & 16.2\end{array}$

15.5

3.4

21.2

$-5.6$

$-1.0$

$-1.0$

$-12.9$

$-14.1$

28.5

$-43.1$

4.0

19.1

3,913

$-10.3$

6.8

10,721

55.0

6.1

1,033

48.6

481.5

17.1
4.1
24.1
-6.9
-1.4
-0.8

16.9

3.9

25.5

$-8.5$

$-2.4$

$-1.1$

$-9.6$

$-11.9$

26.0

$-37.2$

4.2

19.3

4,232

448.0

4,609

$-44.1$

17.0

3.8

24.8

$-7.8$

$-2.0$

$-1.0$

$-7.9$

$-10.2$

28.9

$-38.5$

3.7

24.2

$-9.1$

$-11.2$

30.6

$-39.5$

2.3

26.1

17.2

17.3

3.8

24.2

$-6.9$

$-1.0$

$-1.0 \quad-1.0$

$-9.1$

$-11.2$

31.3

$-39.7$

2.3

27.9

$-8.6$

$-10.7$

31.2

$-39.2$

2.3

29.6

17.4

17.3

$3.8 \quad 3.8$

$24.2 \quad 24.4$

$-6.9 \quad-7.0$

$-1.0 \quad-1.1$

$-1.0 \quad-1.1$

13,631

58.7

6.9
1,602

60.6

449.3

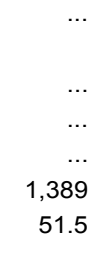

$\begin{array}{rrrrr}5,005 & 5,414 & 5,840 & 6,292 & 6,735 \\ -41.0 & -38.7 & -1.5 & 68.3 & 53.4\end{array}$

Sources: Malian authorities; and IMF staff estimates and projections.

\footnotetext{
${ }^{1}$ Revenue (excluding grants) less total expenditure excluding foreign financed investment projects and HIPC Initiative spending.

${ }^{2}$ Basic fiscal balance excluding spending financed by privatization revenue.

${ }^{3}$ For 2009, reflects new SDR allocation and privatization receipts of SOTELMA.
} 
Table 13. Mali: Millennium Development Goals 1990-2008

\begin{tabular}{l}
\hline \\
Goal 1: Eradicate extreme poverty and hunger \\
Employment to population ratio, $15+$, total $(\%)$ \\
Employment to population ratio, ages $15-24$, total $(\%)$ \\
GDP per person employed (constant 1990 PPP $\$$ ) \\
Income share held by lowest $20 \%$ \\
Malnutrition prevalence, weight for age ( $\%$ of children under 5 ) \\
Poverty gap at $\$ 1.25$ a day (PPP) (\%) \\
Poverty headcount ratio at $\$ 1.25$ a day (PPP) ( $\%$ of population) \\
Vulnerable employment, total ( $\%$ of total employment)
\end{tabular}

\section{Goal 2: Achieve universal primary education}

Literacy rate, youth female (\% of females ages 15-24)

Literacy rate, youth male (\% of males ages $15-24$ )

Persistence to last grade of primary, total (\% of cohort)

Total enrollment, primary ( $\%$ net $)$

Goal 3: Promote gender equality and empower women

Proportion of seats held by women in national parliaments (\%)

Ratio of female to male primary enrollment (\%)

Ratio of female to male secondary enrollment (\%)

Ratio of female to male tertiary enrollment (\%)

Share of women employed in the nonagricultural sector

( $\%$ of total nonagricultural employment)

\section{Goal 4: Reduce child mortality}

Immunization, measles (\% of children ages 12-23 months)

Mortality rate, infant (per 1,000 live births)

Mortality rate, under-5 (per 1,000)

\section{Goal 5: Improve maternal health}

Adolescent fertility rate (births per 1,000 women ages 15-19)

Births attended by skilled health staff ( $\%$ of total)

Contraceptive prevalence (\% of women ages 15-49)

Maternal mortality ratio (estimate, per 100,000 live births)

Pregnant women receiving prenatal care (\%)

Unmet need for contraception (\% of married women ages 15-49)

Goal 6: Combat HIVIAIDS, malaria, and other diseases

Children with fever receiving antimalarial drugs

( $\%$ of children under age 5 with fever)

Condom use, female (\% of females ages 15-24)

Condom use, male ( $\%$ of males ages 15-24)

Prevalence of HIV, total (\% of population ages 15-49)

Tuberculosis case detection rate (all forms)

Goal 7: Ensure environmental sustainability

CO2 emissions (kg per PPP \$ of GDP)

$\mathrm{CO} 2$ emissions (metric tons per capita)

Forest area (\% of land area)

Improved sanitation facilities (\% of population with access)

Improved water source (\% of population with access)

Terrestrial protected areas ( $\%$ of total surface area)

Goal 8: Develop a global partnership for development

Net ODA received per capita (current US\$)

Internet users (per 100 people)

Mobile cellular subscriptions (per 100 people)

Telephone lines (per 100 people)

Other

Fertility rate, total (births per woman)

GNI per capita, Atlas method (current US\$)

Gross capital formation (\% of GDP)

Life expectancy at birth, total (years)

Literacy rate, adult total (\% of people ages 15 and above)
Primary completion rate, total (\% of relevant age group)

Incidence of tuberculosis (per 100,000 people)

$1990 \quad 1995$

2000

2005 2008

2015 target $=$ halve 1990 poverty and malnutrition rates

$\begin{array}{rrrrr}49 & 48 & 49 & 47 & 47 \\ 40 & 39 & 40 & 36 & 35 \\ 1,874 & 1,929 & 2,094 & 2,463 & 2,608 \\ 7 & 5 & 6 & 7 & 7 \\ . . & 38 & 30 & 28 & 28 \\ 13 & 53 & 26 & 19 & 19 \\ 40 & 86 & 61 & 51 & 51 \\ . . & 96 & . . & . . & . .\end{array}$

\begin{tabular}{rrrrr}
\multicolumn{5}{r}{$\mathbf{2 0 1 5}$ target } \\
.. &.. & 17 & 31 & \\
.. &.. & 32 & 47 & 31 \\
.. &.. & 86 & 73 & 47 \\
.. & 16 & 31 & 44 & 76 \\
12 &.. & 45 & 61 & 57 \\
.. & & 400 & 75
\end{tabular}

2015 target $=$ increase education ratio to 100

$\begin{array}{rrrrr}. . & 2 & 12 & 10 & 10 \\ 59 & 67 & 74 & 78 & 83 \\ 51 & . . & 55 & 61 & 64 \\ 16 & . . & 47 & 53 & 45 \\ . . & . . & . . & 35 & . .\end{array}$

2015 target $=$ reduce 1990 under 5 mortality by two-thirds

$\begin{array}{rrrrr}43 & 52 & 49 & 68 & 68 \\ 139 & 132 & 120 & 109 & 103 \\ 250 & 233 & 217 & 202 & 194\end{array}$

2015 target $=$ reduce 1990 maternal mortality by three-fourths

$\begin{array}{rrrrr}. . & . . & 167 & 164 & 161 \\ . . & 40 & 41 & 49 & 49 \\ . . & 7 & 8 & 8 & 8 \\ . . & . . & . . & 970 & . . \\ . . & 94 & 57 & 70 & 70 \\ . . & 26 & 29 & 31 & 31\end{array}$

2015 target $=$ begin to reverse AIDS and other major diseases

32

$\begin{array}{rrrrr}. . & . . & & 32 & 32 \\ . . & 3 & 3 & 4 & 4 \\ . . & 26 & 26 & 29 & 29 \\ 275 & 287 & 300 & 313 & 322 \\ 0 & 1 & 1 & 2 & 2 \\ . . & 12 & 14 & 17 & 21\end{array}$

Source: World Bank, World Development Indicators (http://ddp-ext.worldbank.org/ext/ddpreports).

$\begin{array}{rrrrr}0 & 0 & 0 & 0 & 0 \\ 0 & 0 & 0 & 0 & 0 \\ 12 & 11 & 11 & 10 & 10 \\ 35 & 39 & 42 & 45 & 45 \\ 33 & 42 & 51 & 60 & 60 \\ . . & . . & . . & . . & 2\end{array}$

4

\begin{tabular}{rrrrr}
7 & 7 & 7 & 7 & 7 \\
250 & 250 & 250 & 440 & 580 \\
23 & 23 & 25 & 23 & 23 \\
43 & 44 & 46 & 47 & 48 \\
.. &.. & 19 & 26 & 26 \\
\hline
\end{tabular}

10 4

\section{7} 8 8 9 . 1 7 76
57
5 . 
Table 14. Mali: Doing Business Indicators, 2010

\begin{tabular}{|c|c|c|c|}
\hline & Mali & WAEMU & $\begin{array}{r}\text { Sub-Saharan } \\
\text { Africa }\end{array}$ \\
\hline \multicolumn{4}{|l|}{ Starting a business } \\
\hline Procedures (number) & 7.0 & 8.0 & 9.4 \\
\hline Time (days) & 15.0 & 51.6 & 46.5 \\
\hline Cost (\% of income per capita) & 89.2 & 142.3 & 102.6 \\
\hline Minimum capital (\% of income per capita) & 334.6 & 421.6 & 141.0 \\
\hline \multicolumn{4}{|l|}{ Dealing with Construction Permits } \\
\hline Procedures (number) & 14.0 & 16.1 & 17.2 \\
\hline Time (days) & 185.0 & 285.6 & 259.9 \\
\hline Cost ( $\%$ of income per capita) & 818.5 & $1,018.6$ & $1,997.0$ \\
\hline \multicolumn{4}{|l|}{ Employing Workers } \\
\hline Difficulty of Hiring Index (0-100) & 33.0 & 57.5 & 36.8 \\
\hline Rigidity of Hours Index (0-100) & 20.0 & 37.5 & 29.7 \\
\hline Difficulty of Redundancy Index (0-100) & 40.0 & 40.0 & 39.5 \\
\hline Rigidity of Employment Index (0-100) & 31.0 & 45.0 & 35.3 \\
\hline Redundancy Cost (weeks of salary) & 31.0 & 43.3 & 67.3 \\
\hline \multicolumn{4}{|l|}{ Registering Property } \\
\hline Procedures (number) & 5.0 & 5.4 & 6.7 \\
\hline Time (days) & 29.0 & 116.9 & 83.1 \\
\hline Cost (\% of property value) & 20.0 & 13.9 & 10.2 \\
\hline \multicolumn{4}{|l|}{ Getting Credit } \\
\hline Legal Rights Index (0-10) & 3.0 & 3.0 & 4.7 \\
\hline Credit Information Index (0-6) & 1.0 & 1.0 & 1.5 \\
\hline Public registry coverage (\% adults) & 4.0 & 3.6 & 2.5 \\
\hline Private bureau coverage ( $\%$ adults) & 0.0 & 0.0 & 4.8 \\
\hline \multicolumn{4}{|l|}{ Protecting Investors } \\
\hline Disclosure Index (0-10) & 6.0 & 6.0 & 4.9 \\
\hline Director Liability Index (0-10) & 1.0 & 1.0 & 3.3 \\
\hline Shareholder Suits Index (0-10) & 4.0 & 3.5 & 5.1 \\
\hline Investor Protection Index (0-10) & 3.7 & 3.5 & 4.4 \\
\hline \multicolumn{4}{|l|}{ Paying Taxes } \\
\hline Payments (number) & 58.0 & 53.0 & 37.6 \\
\hline Time (hours) & 270.0 & 311.8 & 297.8 \\
\hline Total tax rate (\% profit) & 52.1 & 50.8 & 67.7 \\
\hline \multicolumn{4}{|l|}{ Trading Across Borders } \\
\hline Documents for export (number) & 7.0 & 7.6 & 7.7 \\
\hline Time for export (days) & 32.0 & 30.6 & 33.5 \\
\hline Cost to export (US\$ per container) & $2,075.0$ & $1,835.6$ & $1,948.9$ \\
\hline Documents for import (number) & 10.0 & 8.3 & 8.8 \\
\hline Time for import (days) & 37.0 & 35.4 & 39.2 \\
\hline Cost to import (US\$ per container) & $2,955.0$ & $2,444.9$ & $2,372.4$ \\
\hline \multicolumn{4}{|l|}{ Enforcing Contracts } \\
\hline Procedures (number) & 36.0 & 39.1 & 38.7 \\
\hline Time (days) & 626.0 & 715.0 & 647.3 \\
\hline Cost (\% of debt) & 52.0 & 50.0 & 50.5 \\
\hline \multicolumn{4}{|l|}{ Closing a Business } \\
\hline Time (years) ${ }^{1}$ & 3.6 & 3.5 & 3.2 \\
\hline Cost $(\% \text { of estate })^{1}$ & 18.0 & 15.3 & 20.6 \\
\hline Recovery rate (cents on the dollar) & 20.9 & 20.7 & 17.6 \\
\hline
\end{tabular}

Source: World Bank, Doing Business Indicators (http://www.doingbusiness.org/economyrankings/).

${ }^{1}$ WAEMU indicators exclude Guinea-Bissau. SSA indicators exclude Burundi, Cape Verde, Chad, Comoros, Equatorial Guinea, Eritrea, Guinea-Bissau, Madagascar, Rwanda, São Tomé and Príncipe, and Seychelles. 
Table 15. Mali: Indicators of Capacity to Repay the Fund, 2008-14 ${ }^{1}$

\begin{tabular}{|c|c|c|c|c|c|c|c|}
\hline & 2008 & 2009 & 2010 & 2011 & 2012 & 2013 & 2014 \\
\hline & \multicolumn{7}{|c|}{ (in millions of SDRs) } \\
\hline \multicolumn{8}{|l|}{ Fund obligations based on existing credit } \\
\hline Principal & 0.0 & 0.0 & 0.1 & 0.5 & 1.2 & 2.9 & 5.2 \\
\hline Charges and interest & 0.5 & 0.5 & 0.2 & 0.2 & 0.2 & 0.2 & 0.2 \\
\hline \multicolumn{8}{|c|}{ Fund obligations based on existing and prospective credit } \\
\hline Principal & 0.0 & 0.0 & 0.1 & 0.5 & 1.2 & 2.9 & 10.8 \\
\hline Charges and interest & 0.5 & 0.6 & 0.3 & 0.3 & 0.3 & 0.3 & 0.3 \\
\hline \multicolumn{8}{|c|}{ Total obligations based on existing and prospective credit } \\
\hline In millions of SDRs & 0.5 & 0.6 & 0.5 & 0.9 & 1.5 & 3.2 & 11.1 \\
\hline In billions of CFA francs & 0.7 & 0.8 & 0.6 & 1.1 & 2.0 & 4.4 & 14.9 \\
\hline In percent of government revenue & 0.1 & 0.1 & 0.1 & 0.1 & 0.2 & 0.5 & 1.5 \\
\hline In percent of exports of goods and services & 0.1 & 0.1 & 0.0 & 0.1 & 0.1 & 0.2 & 0.8 \\
\hline In percent of debt service ${ }^{<}$ & 0.1 & 0.2 & 0.2 & 0.2 & 0.4 & 0.9 & 2.9 \\
\hline In percent of GDP & 0.0 & 0.0 & 0.0 & 0.0 & 0.0 & 0.1 & 0.2 \\
\hline In percent of quota & 0.5 & 0.6 & 0.5 & 0.9 & 1.6 & 3.4 & 11.9 \\
\hline \multicolumn{8}{|l|}{ Outstanding Fund credit ${ }^{2}$} \\
\hline In millions of SDRs & 26.0 & 28.0 & 33.9 & 35.3 & 34.1 & 31.2 & 20.4 \\
\hline In billions of CFA francs & 36.9 & 38.5 & 44.9 & 46.0 & 44.1 & 42.3 & 27.4 \\
\hline In percent of government revenue & 6.8 & 5.9 & 6.3 & 5.9 & 5.2 & 4.6 & 2.8 \\
\hline In percent of exports of goods and services & 3.3 & 3.5 & 3.4 & 3.0 & 2.6 & 2.3 & 1.4 \\
\hline In percent of debt service ${ }^{<}$ & 7.3 & 9.5 & 12.3 & 10.1 & 9.0 & 8.4 & 5.4 \\
\hline In percent of GDP & 0.9 & 0.9 & 1.0 & 0.9 & 0.8 & 0.7 & 0.4 \\
\hline In percent of quota & 27.9 & 30.0 & 36.3 & 37.9 & 36.6 & 33.5 & 21.9 \\
\hline Repayments and Repurchases & 18.0 & 2.0 & 5.9 & 1.5 & -1.2 & -2.9 & -10.8 \\
\hline Disbursements & 18.0 & 2.0 & 6.0 & 2.0 & 0.0 & 0.0 & 0.0 \\
\hline Repayments and Repurchases & 0.0 & 0.0 & 0.1 & 0.5 & 1.2 & 2.9 & 10.8 \\
\hline Memorandum items: & \multicolumn{7}{|c|}{ (in billions of CFA francs, unless otherwise indicated) } \\
\hline Nominal GDP & 3912.8 & 4232.0 & 4609.2 & 5005.4 & 5414.4 & 5840.4 & 6292.5 \\
\hline Exports of goods and services & 1116.9 & 1100.8 & 1330.4 & 1532.0 & 1694.4 & 1824.3 & 1954.4 \\
\hline Government revenue & 540.6 & 653.2 & 709.0 & 774.0 & 847.8 & 918.6 & 991.8 \\
\hline Debt service ${ }^{<}$ & 504.8 & 406.8 & 365.2 & 457.5 & 492.1 & 502.3 & 504.7 \\
\hline CFA francs/SDR (period average) & 704.6 & 726.5 & $\ldots$ & $\ldots$ & $\ldots$ & $\ldots$ & $\ldots$ \\
\hline
\end{tabular}

Sources: IMF staff estimates and projections.

1/ Assumes ECF (formerly PRGF) access in an amount of SDR 27.99 million.

2/ Total debt service includes IMF repurchases and repayments. 
Table 16. Mali: Schedule of Disbursements Under the ECF Arrangement, 2008-11

\begin{tabular}{|c|c|c|c|}
\hline Amount & Available date & Disbursement date & Conditions for disbursement ${ }^{1}$ \\
\hline SDR 12.99 million & May 28, 2008 & June 18, 2008 & $\begin{array}{l}\text { Executive Board approval of the three } \\
\text { year ECF arrangement. }\end{array}$ \\
\hline SDR 5.00 million & December 10, 2008 & December 22, 2008 & $\begin{array}{l}\text { Observance of the performance criteria } \\
\text { for June } 30,2008 \text {, and completion of } \\
\text { the first review under the arrangement }\end{array}$ \\
\hline SDR 2.00 million & July 6 , 2009 & July 13, 2009 & $\begin{array}{l}\text { Observance of the performance criteria } \\
\text { for December } 31,2008 \text {, and completion } \\
\text { of the second review under the } \\
\text { arrangement }\end{array}$ \\
\hline SDR 2.00 million & January 11, 2009 & February 10, 2010 & $\begin{array}{l}\text { Observance of the performance criteria } \\
\text { for June } 30,2009 \text {, and completion of } \\
\text { the third review under the arrangement }\end{array}$ \\
\hline SDR 2.00 million & May 15, 2010 & July 15, 2010 & $\begin{array}{l}\text { Observance of the performance criteria } \\
\text { for December } 31,2009 \text {, and completion } \\
\text { of the fourth review under the } \\
\text { arrangement }\end{array}$ \\
\hline SDR 2.00 million & November 15, 2010 & December 1, 2010 & $\begin{array}{l}\text { Observance of the performance criteria } \\
\text { for June } 30,2010 \text {, and completion of } \\
\text { the fifth review under the arrangement }\end{array}$ \\
\hline SDR 2.00 million & May 15, 2011 & June 1, 2011 & $\begin{array}{l}\text { Observance of the performance criteria } \\
\text { for December } 31,2010 \text {, and completion } \\
\text { of the sixth review under the } \\
\text { arrangement }\end{array}$ \\
\hline
\end{tabular}

Source: International Monetary Fund.

1 In addition to the generally applicable conditions under the Extended Credit Facility arrangement 
APPENDIX I

Program of the Government of Mali Supported by an
Arrangement under the Extended Credit Facility

LETTER OF INTENT FOR THE 4TH REVIEW

Bamako, June 28, 2010

Mr. Dominique Strauss-Kahn

Managing Director

International Monetary Fund

Washington, D.C. 20431

U.S.A.

Sir:

1. Implementation of our economic and financial program supported by the International Monetary Fund through an arrangement under the Extended Credit Facility (ECF) was satisfactory in 2009 and the results achieved were encouraging. Unlike the surge in global food and energy prices in 2008, the 2009 international financial crisis and global recession had only a limited impact on the national economy. In 2010, the year of our fiftieth anniversary of independence, we intend to continue our efforts to promote sustained economic growth with a view to improving the living standards of the population and reducing poverty. Attainment of these objectives is contingent on maintaining macroeconomic stability and deepening important structural reforms, particularly in the area of public financial management.

\section{A. Program implementation in 2009 and in the first quarter of $\mathbf{2 0 1 0}$}

2. The economic climate was relatively positive in 2009. As stated in our letter of December 23 last, favorable prices for gold-which accounts for 75 percent of our export earnings - the fall in world energy and food prices following their steep rise in 2008, and a second consecutive year of good rainfall meant that the Malian economy was not unduly affected by the adverse effects of the global recession.

3. Gross domestic product (GDP) grew by 4.5 percent in real terms, driven mainly by the good results of the crop year. These good results also helped bring average inflation down 
from 9.1 percent in 2008 to 2.2 percent in 2009, against the backdrop of the easing of regional monetary conditions by the Central Bank of West African States (BCEAO).

4. Helped by the evolution of international prices of gold, petroleum products and food, the external current account deficit showed only a slight dip despite a drop of around 15 percent in migrant workers' remittances and a decline in revenue from tourism as a consequence of both the global recession and security problems in the north of the country.

5. The capital account balance also improved markedly owing essentially to the IMF SDR allocations and the rise in foreign direct investment, which was in turn largely attributable to the partial privatization of Société des Télécommunications du Mali (SOTELMA), resulting in an appreciable increase in Mali's contribution to the international reserves of the West African Economic and Monetary Union (WAEMU).

6. These good results overall reflect not only favorable external factors but also the implementation of prudent macroeconomic policies. The government's underlying basic fiscal balance (excluding expenditures financed by the Highly Indebted Poor Countries (HIPC) Initiative and receipts from the privatization of SOTELMA) recorded a deficit of CFAF 32.7 billion ( 0.8 percent of GDP) in 2009, as opposed to the 1.4 percent of GDP projected during the third program review and compared with a deficit of 1 percent of GDP in 2008. The basic deficit, including expenditures financed by SOTELMA, was contained at 1.4 percent of GDP compared with a target of 1.8 percent. This outcome is a reflection of strong tax revenue performance, especially indirect taxes, and control of spending. Revenue overshot their targets by 0.5 percentage point to reach 15.4 percent of GDP. On the expenditure side, savings on current expenditure made it possible to offset an overrun in domestic financed capital outlays and net lending.

7. Despite improved control of the basic fiscal balance, we were unable to meet the target for reducing the government's budgetary float vis-à-vis its suppliers and Treasury correspondents at end-2009. The budgetary float of CFAF 145.7 billion at end-2008 was reduced to CFAF 129.1 billion at end-2009, compared with the CFAF 66 billion targeted in the program. This outcome can be explained by the stepped up pace of expenditures in the last quarter of 2009, following the strict regulation of spending over the first nine months of the year, and the late disbursement of CFAF 32 billion in external budgetary assistance in the last days of the month of December 2009. The issuance and the settlement of payment orders in the fourth quarter were consequently carried over in part to 2010 in the form of new budgetary float. Nevertheless, the deposits accumulated at December 31, 2009 were used in the first quarter of 2010 to reduce the budgetary float to CFAF 55.2 billion at end-March 2010, that is below the target initially set for end-2009. These significant fluctuations of the budgetary float strengthen our determination to make further improvements in the forward management of government cash flow. If one takes into account the reduction of the Value Added Tax (VAT) credits owed to mining companies from CFAF 69 billion at end-December 2008 to CFAF 29 billion at end-December 2009, the pending bills of the State 
have been reduced from CFAF 215 billion to CFAF 158 billion over the same period. We intend to reduce this level of pending bills to CFAF 80 billion at end-December 2010 .

8. All the performance criteria of the program for end-December 2009 were met, including the two related to net domestic financing of the government, which were corrected to take account of VAT arrears clearance operations and the underperformance noted with regard to the reduction of the budgetary float. In addition, the three structural benchmarks for end-December 2009 on the (i) adoption of a strategy and a timetable for government divestment of the state-owned housing bank (BHM), (ii) finalization of a study on the macroeconomic impact of the gold sector, and (iii) preparation, jointly with the BCEAO, of an inventory of the accounts included in the net position of the government vis-à-vis the banking system and of an appropriate methodology for recording the movements of the accounts in the table of the government's financial operations (TOFE).

9. However, the benchmark on the putting in place of a system to monitor the budgetary float has not been met, particularly as a result of delays in implementing the new integrated government accounting software application. A coordination unit was set up at the National Directorate of the Treasury and Public Accounting (DNTCP) to support the provider in accelerating the operationalization of the software. Pending the implementation of the real time monitoring system, outstanding payments continue to be monitored on a regular basis through the expenditure chain. Since end-April 2010, the DNTCP has also been receiving technical assistance from an IMF resident expert for the implementation of the new public accounting management integrated software.

10. We have continued to observe satisfactory economic and financial developments in 2010. International market trends remain favorable to Mali; national economic growth indicators are encouraging; and average inflation has continued to subside to reach 1.2 percent at end-April. The launching of the 2010/11 agricultural campaign was done under good conditions and is supported by favorable initial weather conditions, except in the East of the country where a drought persists and results in pockets of food shortages that we aim at addressing through our food security program and with our development partners. The implementation of our program remains satisfactory; based on preliminary data, the indicative quantitative targets at end-March 2010 have been observed.

\section{B. Outlook for 2010}

11. The revision of our economic and financial program for 2010 is based on the objectives and commitments made under the third program review. Essentially, it reflects the implementation of a fiscal policy that targets higher growth through an increase of nonrecurrent spending financed by revenues from the privatization of SOTELMA. We intend to continue to focus on prudent public financial management and the deepening of key structural reforms in pursuit of the objectives contained in the Poverty Reduction and Growth 
Strategy Framework (CSCRP). The support of Mali's technical and financial partners (TFPs) remains vital for our ongoing efforts in this direction.

12. Economic growth is expected to exceed 5 percent in 2010 , fuelled by the upturn in both regional and global economic activity, our adjusted fiscal policy, and the projected good agricultural harvest. According to current forecasts, cotton ginning is set to recover and more robust activity is projected in the building, public works, and tertiary sectors. At the regional level, the BCEAO will continue to pursue a prudent monetary policy to anchor inflation expectations and stabilize inflation at around 2 percent in Mali. However, despite the continued solid performance of gold prices on the world market and the rise in cotton prices, our external position may deteriorate slightly as foreign direct investment tapers off from the exceptionally high level reached in 2009 as a result of the privatization of SOTELMA. Further, our economy remains very heavily dependent on rainfall and continues to be vulnerable to new exogenous shocks, including on its terms of trade.

\section{Fiscal policy}

13. The government stands by the commitments and fiscal objectives adopted in its previous letter of intent. Thus, prior to the conclusion of the fourth program review, the government intends to submit to the National Assembly a supplementary budget incorporating various policy components that could not be taken into account at the time of the vote on the initial budget for 2010 .

14. In the supplementary budget law for 2010, the target for the basic deficit (excluding HIPC expenditure) has been increased from 1.6 to 2.4 percent of GDP, reflecting an increase in non-recurrent spending financed by SOTELMA privatization receipts. As regards the underlying basic deficit, that is, excluding expenditures financed by SOTELMA, the initial target level remains unchanged at 1.1 percent of GDP as both revenue and expenditure measures have been put in place to offset the new fiscal spending amounting to around 0.8 percent of GDP.

15. The revenue target remains unchanged at 15.4 percent of GDP. The supplementary budget includes an amount of CFAF 5 billion paid by a telecommunications company for a third-generation (3G) license. Further, in view of the efforts made by the Directorate-General of Taxes (DGI) in the area of tax administration, its revenue target for 2010 has been revised upwards by CFAF 3 billion. To ensure that its revenue targets are met, the government will continue its policy of reflecting international oil price fluctuations in domestic prices. Petroleum product prices were, therefore, raised last April. Good revenue performance in the first quarter of 2010, in line with the program, also offers sufficient justification for keeping the revenue target unchanged.

16. On the expenditure side, we have finalized the broad outlines for use of the SOTELMA privatization proceeds to finance non-recurrent expenditures over the 2009-12 
period (see attached Table 1). The revised 2010 budget law takes on board an additional CFAF 30.9 billion in expenditures to be financed by these proceeds, that is, an increase of 0.9 percent of GDP bringing the total to 1.4 percent of GDP. The planned expenditure concerns mostly capital expenditure to support economic growth. The transparent management and close monitoring of the use of the privatization receipts will be ensured through specific allocations in the budget laws and the use of a sub-account of the Treasury in the BCEAO, which was opened especially for the recording and use of this revenue.

17. The supplementary budget also provides an opportunity for budget support needs in the context of efforts to revive the cotton sector and the agricultural inputs subsidization policy for the 2010/11 crop season to be reflected more adequately. These needs have arisen from recent information on the conduct of the crop season and decisions taken in March 2010 by the Higher Council for Agriculture. The budget allocation of CFAF 13.9 billion included in the initial budget law for the subsidization of agricultural inputs will be increased by CFAF 7.8 billion to incorporate expenditures planned under this item for the 2010/11 crop season. Similarly, budget support to the cotton sector in 2010 will be increased by CFAF 16.1 billion, including CFAF 8.7 billion corresponding to assumption by government of the costs of the CMDT employee reduction scheme, a CFAF 2 billion contribution to the efforts to rehabilitate the cotton ginning plant, CFAF 2 billion for the settlement of banking payment arrears, and CFAF 3.4 billion to clear the arrears on invoices for inputs from the 2006/07 and $2007 / 08$ crop seasons. The adequacy of these additional expenditures to meet the needs of supporting agricultural inputs and the cotton sector will be assessed in the context of the fifth program review.

18. The supplementary budget law also includes an adjustment of the amounts to cover expenditures for interest payments on domestic debt and the holding of a constitutional referendum before the end of the year. This referendum opens the way for important institutional reforms aimed at consolidating our democracy. Among other things, the proposed reforms address the creation d'un Senate, an Audit Office (Cour des Comptes) to strengthen existing provisions for ex-post control of budget execution, and a single, independent audiovisual regulatory authority.

19. Thus, the new expenditures contained in the supplementary budget law amount in total to CFAF 63.9 billion, i.e., 1.4 percent of GDP, broken down as follows: 7.0 billion in expenditures of goods and services, 19.1 billion in transfers and subsidies, 4.0 billion in interest on domestic debt, 28.9 billion in capital expenditure, and 7.4 billion in net lending. SOTELMA privatization receipts will finance the increased level of capital expenditure and CFAF 2 billion of net lending, in addition to the CFAF 28.9 billion already included in the initial budget law, i.e., a total of CFAF 59.8 billion.

20. In the light of the new expenditure and revenue, the government has committed in the supplementary budget law to making savings on expenditure during the execution of the budget law so as to limit the underlying basic deficit to CFAF 52.6 billion, that is the initial 
target of 1.1 percent of GDP. Twenty-five percent of the planned budget savings, estimated at about CFAF 20 billion, or 0.4 percent of GDP, will be in the area of goods and services, twenty-five percent in subsidies and transfers, and fifty-percent in capital expenditure.

21. The government's overall budget deficit, on a commitment basis and excluding grants, is targeted at CFAF 393 billion, i.e., 8.5 percent of GDP versus actual figures of 6.9 percent of GDP in 2009. Taking into account net external financing, including grants, estimated at 3.9 percent of GDP, the need for domestic financing of this fiscal stimulus to support growth is limited to 1.1 percent of GDP. To this need should also be added, however, the projected reduction of the stock of outstanding payments at end-2009 by CFAF 49 billion. In addition, the government has accumulated CFAF 29 billion in new arrears of VAT credit reimbursements to four mining companies whose tax amnesty period recently expired. These arrears will be settled in 2010, possibly through a rescheduling agreement over 3 years.

22. The overall need for domestic financing of the budget, therefore, amounts to 2.8 percent of GDP. It will be met primarily by drawing on the exceptional revenues from the privatization of SOTELMA (1.3 percent of GDP), deposits constituted at end-2009 ( 0.7 percent), and rescheduling of the VAT arrears ( 0.4 percent).

\section{Structural Reforms}

23. We are pursuing our efforts to improve public financial management supported by our TFPs. In the wake of the satisfactory implementation of the action plan for improving and modernizing public financial management (PAGAM/GFP), a second generation of reforms is under preparation (PAGAM 2) in line with standards of the Public Expenditure and Financial Accountability (PEFA) framework. In the strategic plan, the PAGAM/GFP2 are aimed mainly at:

- Optimizing government revenues on a sustainable basis,

- Improving the quality of budget preparation and execution to encourage our partners to use budget support as the preferred form of assistance,

- $\quad$ Strengthening the system of financial governance by improving the efficiency of expost controls by the Accounts Section,

- $\quad$ Stepping up fiscal deconcentration and decentralization supported, starting in 2010, by a three-year World Bank technical assistance program.

24. Improving the mobilization of domestic financial resources remains one of the government's main priorities. To this effect, we will adopt a national tax transition program with a view to increasing the tax revenue to GDP ratio to 17 percent in the medium term, with emphasis on broadening the tax base and revamping existing exemption arrangements 
(structural benchmark). The program will include a study on the tax potential of Mali as well as a new generation of tax reforms aimed at modernizing and streamlining our tax system for which we are seeking IMF technical assistance. Against that backdrop and in the context of transposing WAEMU directives on taxation into the national legislation, a number of draft legislative texts will be prepared for submission to the National Assembly, including legislation to reduce corporate taxes and introduce a land tax on developed and undeveloped property. A draft new mining code will be prepared by end-December 2010 that will cover other mineral resources beyond gold, facilitate mining research and exploration, and be integrated in the program to modernize and streamline the tax system.

25. The Directorates-General of Taxes (DGI) and of Customs (DGD) will continue their efforts to improve tax and customs administration, with technical assistance from the IMF. The DGI will continue to pay special attention to the functioning of the new Medium Taxpayer Office (MTO). Along similar lines, the DGD will continue to work towards introducing an automated targeting system for customs inspections by early 2011. Efforts will also to needed to modernize and strengthen the capacity of the National Directorate of Government Lands and Property Registry (DNDC), established in 2002, as part of the broader objective of boosting revenue recollection. A program to enhance the DNDC will be approved by end-2010.

26. The government will implement by end-December 2010, in consultation with the Fund, a VAT management system that respects the integrity of the tax and provides an effective mechanism for the prevention and the reimbursement of VAT credit arrears (structural benchmark). In this context, it commits to resolving the problems of accumulation and reimbursement of VAT credits in general and of export companies in particular.

27. In the context of the transition to result-oriented budgets, we have effectively started in April 2010 the migration of our public spending management software to a new version (PRED5). The modules for the preparation and execution of the budget have been parameterized and output tables prepared. Test operations are ongoing with a view to make it fully operational by end-June 2010. A new public accounting software will also be operational at end-2010 and inter-connected with the public spending management software to ensure a monitoring not only of budgetary execution up to the final payment stage but also of pending bills (structural benchmark).

28. Significant progress has been made towards the introduction, by end-June 2010, of a new government flow of funds table (TOFE) in which the presentation of domestic financing (bank and nonbank) will be consistent with international best practices. These efforts aimed at improving budgetary statistics will be pursued in the second half of 2010 and incorporated into the ongoing work to upgrade the rolling projected cash-flow plan to strengthen cash management. 
29. In addition, the National Public Debt Committee (CNDP) established by Decree of September 24, 2009 will become operational by end-September 2010 by the adoption of regulations regarding its operations and the nomination of the members of the technical commission of the CNDP. The CNDP is responsible for examining all domestic or external debt plans and requests for guarantees prior to any final decision by the government. The reporting and the management of the domestic debt will be strengthened with a view to, first, ensuring the exhaustivity of data at the level of the CNDP and, second, improving the programming of the recourse to regional financial markets.

\section{Other structural reforms}

30. The government will continue to implement the recommendations of the 2008 Financial Sector Assessment Program (FSAP), in keeping with the financial system development strategy adopted in the same year. Particular attention will be paid to implementation of the restructuring plan of the BHM, with the goal of divestment of the government's interests in 2012. Thus, by end-December 2010, the government will proceed with the recruitment of a privatization advisor. It will conduct an evaluation of the restructuring plan of the BHM, including the use of the government funds transferred for the renewed lending activities of the BHM in the first half of 2010, in collaboration with the BCEAO (structural benchmark).

31. For the cotton sector, the call for expressions of interest in the privatization of the cotton parastatal CMDT was published in February 2010. A special workshop in April 2010 validated the draft of the national strategic framework for the development of the cotton sector, and the final report will be ready by end-June 2010. The government will ensure that this privatization operation takes place in the best conditions to ensure the economic and financial sustainability of the sector.

\section{Modalities for monitoring the program}

32. Discussions on the fifth program review will focus on the implementation of structural reforms and on the draft budget for 2011 taking into account the fiscal anchor on an underlying basic deficit of around 1 percent of GDP.

33. Performance under the current program will be evaluated on the basis of Tables 3 and 5 and the Technical Memorandum of Understanding attached. In that context, we request the modification of the end-June 2010 quantitative performance criteria and benchmarks, which takes into account the end-2009 outcome and recent developments. It is envisaged that the fifth program review will be concluded by end-2010 on the basis of the performance criteria at end-June 2010 and that the sixth review will be completed by end-May 2011 on the basis of the performance criteria at end-2010. 
34. The government requests that the Executive Board of the IMF complete the fourth review of Mali's ECF arrangement and approve the disbursement of the fifth loan equivalent to SDR 2 million. The government considers that the policies described in this letter are sufficient to achieve its program objectives. It will, however, take any other measures that may prove necessary to that end. Mali will consult with the Fund on the adoption of these measures and in advance of any revision to the policies contained in this letter, in accordance with the Fund's policies on such consultation. The government will provide Fund staff with any required information contained in the Technical Memorandum of Understanding on progress made in implementing the program. During the program, the government will not introduce or intensify any exchange restrictions, multiple currency practice, or import restriction for balance of payments of purposes, nor conclude any bilateral payment agreements that are inconsistent with Article VIII of the Fund's Articles of Agreement. The government authorizes the IMF to publish this letter, and the related Staff Report on this review.

Yours sincerely,

$/ \mathrm{s} /$

Mr. Sanoussi Touré

Minister of Economy and Finance 
Table 1. Mali-Use of Proceeds from Partial Privatization of Sotelma, 2009-2012

(In billions of CFA Francs)

\begin{tabular}{|c|c|c|c|c|c|}
\hline & $\begin{array}{c}2009 \\
\text { Est. }\end{array}$ & $\begin{array}{c}2010 \\
\text { Proj. }\end{array}$ & $\begin{array}{c}2011 \\
\text { Proj. }\end{array}$ & $\begin{array}{c}2012 \\
\text { Proj. }\end{array}$ & $\begin{array}{r}\text { Total } \\
\text { Proj. }\end{array}$ \\
\hline Fiscal consolidation / Reduction of domestic debt and payment arrears & $\underline{9,451}$ & $\underline{2,000}$ & $\underline{15,274}$ & $\underline{15,274}$ & $\underline{42,000}$ \\
\hline Vis-à-vis economic agents & - & - & 12,000 & 12,000 & 24,000 \\
\hline Vis-à-vis banks & 9,451 & 2,000 & 3,274 & 3,274 & 18,000 \\
\hline Human resources development & $\underline{1,000}$ & $\underline{11,253}$ & $\underline{5,255}$ & - & $\underline{17,508}$ \\
\hline Youth, Education, Employment & - & 9,300 & $\overline{5,255}$ & - & 14,555 \\
\hline Higher education & - & 3,900 & 3,755 & - & 7,655 \\
\hline Construction of university infrastructure at Bamako and Ségou & - & 3,188 & 3,755 & - & 6,943 \\
\hline Creation of a competitive-access research fund & - & 500 & - & - & 500 \\
\hline Interconnection University of Bamako & - & 212 & - & - & 212 \\
\hline Secondary education, vocational training, youth and employment & - & 5,900 & 1,500 & - & 6,900 \\
\hline Construction and equipping of Technical High Schools and IFPs (1) & - & 4400 & 1,500 & - & 5,400 \\
\hline Strengthening of APEJ financial capacity & - & 1,500 & 500 & - & 1,500 \\
\hline Health and social development & 1,000 & 1,953 & - & - & 2,953 \\
\hline Supplement for construction of Mopti Hospital & - & 1,000 & - & - & 1,000 \\
\hline Supplement for construction of Sikasso Hospital & 1,000 & - & - & - & 1,000 \\
\hline Computer equipment for the Compulsory Sickness Insurance System & - & 953 & - & - & 953 \\
\hline Infrastructure and equipment & - & $\underline{7,747}$ & $\underline{6,863}$ & - & $\underline{14,610}$ \\
\hline Roads and bridges & - & 3,375 & 3,875 & - & 7,250 \\
\hline Kayes : paving of the Bafoulabé-Mahina road (6 km) & - & 1,000 & - & - & 1,000 \\
\hline Koulikoro : street paving $(5 \mathrm{~km})$ & - & 1,000 & - & - & 1,000 \\
\hline Kidal : street paving $(5 \mathrm{~km})$ & - & 375 & 875 & - & 1,250 \\
\hline Bamako: construction of access road to Yirimadio Hospital & - & 1,000 & - & - & 1,000 \\
\hline Sikasso : Bridge over the Baoulé between Manankoro-Tienfinzo & - & - & 3,000 & - & 3,000 \\
\hline Communication and Transport & - & 4,372 & 2,988 & - & 7,360 \\
\hline $1 \mathrm{OB}$ van, 12 cameras & - & 1,950 & - & - & 1,950 \\
\hline 1 Production van, cameras & - & 700 & - & - & 700 \\
\hline 1 Mobile radio/TV production unit & - & 45 & 105 & - & 150 \\
\hline 1 Vehcile fly and accessories & - & 108 & 252 & - & 360 \\
\hline 1 Transmitting earth station & - & 669 & 531 & - & 1,200 \\
\hline Purchase of 2 flat-bottom boats for COMANAV & - & 900 & 2100 & - & 3,000 \\
\hline Agricultural development & - & $\underline{13,675}$ & $\underline{225}$ & - & $\underline{13,900}$ \\
\hline Local improvements & - & 3,330 & 225 & - & 3,555 \\
\hline Upgrade/maintenance of extension service facilities Niger Office & - & 4,100 & - & - & 4,100 \\
\hline Funding for the National Agriculture Development Fund & - & 5,000 & - & - & 5,000 \\
\hline Development/improvement support & - & 445 & - & - & 445 \\
\hline PRODEVALAIT (2) & - & 800 & - & - & 800 \\
\hline Improvement of living standards & - & $\underline{18,206}$ & $\underline{5,708}$ & - & $\underline{23,914}$ \\
\hline Funding for the National Investment Fund for Local Governments & - & 6,000 & 4,000 & - & 10,000 \\
\hline Hydraulic works & - & 3,000 & 2,000 & - & 5,000 \\
\hline Public lighting Bamako & - & 1,000 & - & - & 1,000 \\
\hline Solar energy & - & 2,000 & 2,000 & - & 4,000 \\
\hline Rehabilitation of army barracks & - & 3,292 & 1,708 & - & 5,000 \\
\hline Social Housing Program & - & 6,500 & - & - & 6,500 \\
\hline Construction of Fiftieth Anniversary Monument & - & 800 & - & - & 800 \\
\hline Development of DIAFRANA KO & - & 1,614 & - & - & 1,614 \\
\hline Financial support for SME/microenterprise development & - & - & $\underline{10,000}$ & - & $\underline{10,000}$ \\
\hline Creation of a private sector guarantee fund & - & - & 5,000 & - & 5,000 \\
\hline Creation of a National Investment Fund & - & - & 5,000 & - & 5,000 \\
\hline Economic reform and governance & - & $\underline{6,900}$ & - & - & $\underline{6,900}$ \\
\hline Restructuring of $\mathrm{BHM}$ & - & $\overline{5,000}$ & - & - & $\overline{5,000}$ \\
\hline Support for RAVEC & - & 1,900 & - & - & 1,900 \\
\hline Public investment in partnership with donors & - & - & - & 36,556 & $\underline{36,556}$ \\
\hline Creation of a technology cluster & - & - & - & $\ldots$ & $\ldots$ \\
\hline Connection of secondary towns to the national road network $>100 \mathrm{Km}$ & - & - & - & $\ldots$ & $\ldots$ \\
\hline Construction of a second bridge at Kayes, & - & - & - & $\ldots$ & $\ldots$ \\
\hline Improvement/development of the Faguibine System, & - & - & - & $\ldots$ & $\ldots$ \\
\hline Development of the Bamako Sénou industrial park, & - & - & - & $\ldots$ & $\ldots$ \\
\hline Modernized cadastre for the cities of Bamako and Kati & - & - & - & $\ldots$ & $\ldots$ \\
\hline Strengthening of regional government and military logistic capacities & - & - & - & $\ldots$ & $\ldots$ \\
\hline Social plan & 15,000 & - & - & - & $\underline{15,000}$ \\
\hline Total & 25,451 & 59,781 & 43,325 & 51,830 & 180,388 \\
\hline
\end{tabular}

CInternational Monetary Fund. Not for Redistribution 
Table 2. Mali: Quantitative Performance Criteria and Indicative Targets for $2009^{1}$

\begin{tabular}{|c|c|c|c|c|c|c|c|c|c|c|c|}
\hline \multicolumn{3}{|c|}{ March } & \multicolumn{3}{|c|}{ June } & \multicolumn{3}{|c|}{ Sept. } & \multicolumn{3}{|c|}{ Dec. } \\
\hline $\begin{array}{r}\text { Indic. } \\
\text { Targets }\end{array}$ & Adjusted & Actual & $\begin{array}{r}\text { Rev. Perf. } \\
\text { Criteria }\end{array}$ & Adjusted & Actual & $\begin{array}{r}\text { Rev. Ind. } \\
\text { Targets }\end{array}$ & Adjusted & Actual & $\begin{array}{r}\text { Rev. } \\
\text { Perf. Crit }\end{array}$ & Adjusted & Actual \\
\hline
\end{tabular}

Quantitative performance criteria

Net domestic financing of the Government (ceiling) ${ }^{2}$

Of which: Bank and market financing ${ }^{2}$

Cumulative increase in external payments arrears (ceiling) ${ }^{3}$

New external borrowing at terms of one year or more contracted or

guaranteed by the government on nonconcessional terms ${ }^{3,4}$

New short-term external credits (less than one year)

contracted or guaranteed by the government (ceiling) ${ }^{3}$

Net tax revenue

$\begin{array}{rrrrrrrrrrrr}10.0 & 11.8 & 13.1^{7} & 45.0 & 40.1 & -5.0 & 50.0 & 32.9 & -4.3 & 49.4 & 46.0 & 26.6 \\ 15.0 & 16.8 & 22.3^{7} & 80.0 & 75.1 & 55.1 & 90.0 & 72.9 & -136.9 & -101.5 & -104.9 & -105.9 \\ 0.0 & 0.0 & 0.0 & 0.0 & 0.0 & 0.0 & 0.0 & 0.0 & 0.0 & 0.0 & 0.0 & 0.0 \\ & & & & & & & & & & & \\ 0.0 & 0.0 & 17.5^{8} & 0.0 & 0.0 & 0.0 & 0.0 & 0.0 & 0.0 & 0.0 & 0.0 & 0.0 \\ & & & & & & & & & & & 0.0 \\ 0.0 & 0.0 & 0.0 & 0.0 & 0.0 & 0.0 & 0.0 & 0.0 & 0.0 & 0.0 & 0.0 & 0.0 \\ 140.0 & 140.0 & 143.5 & 290.0 & 290.0 & 319.9 & 430.0 & 430.0 & 451.3 & 603.0 & 603.0 & 624.3\end{array}$

\section{Financial indicators (floors)}

Basic fiscal balance

$-10.0$

17.1

$-20.0$

$-20.0$

66.1

$-40.0$

$-40.0$

23.7

$-78.0 \quad-78.0$

$-58.1$

Underlying basic fiscal balance

\section{Memorandum items:}

External budgetary assistance during the year ${ }^{16}$

HIPC Initiative debt relief

Expenditure financed with HIPC Initiative resources

$\begin{array}{lr}\cdots & 6.4 \\ \cdots & 1.8\end{array}$

38.5
6.3

$\begin{array}{rrr}\ldots & 13.0 & 52.0 \\ \ldots & 9.4 & 8.1\end{array}$

$\begin{array}{ll}\ldots & 53.2 \\ \ldots & 10.8\end{array}$

92.0

Balance of HIPC Initiative resources

${ }^{1}$ Cumulative figures from the beginning of each year. Noncontinuous performance criteria at end-March and end-September 2009 are quantitative benchmarks. See technical memorandum of understandings for definitions.

${ }^{2}$ These quantitative targets are before payment of VAT credits in arrears. The revised targets for the end-June, end-September, and end-December 2009 reflect the recapitalization of the Housing Bank of Mali (BHM) for CFAF 19.1 billion in May 2009 and net projected reductions of the payment float by CFAF 45 billion at end-June and end-September 2009, and CFAF 30 billion at end-December 2009 (the program includes an adjustor for any deviations from the targets on the reduction of the payment float).

${ }^{3}$ These performance criteria will be monitored on a continuous basis.

${ }^{4}$ Grant component equal to or higher than 35 percent.

${ }^{5}$ Excluding expenditures financed with funds from the privatization of SOTELMA.

${ }^{6}$ General budget support only.

${ }^{7}$ The nonobservance of the quantitative indicators for net domestic financing and bank and market financing results from a bond issue that was initiated in December 2008 but effective on January 2, 2009, leading to a downward correction of

CFAF 12.3 billion at end-December 2008 and an upward revision of the same amount at end-March 2009 in market financing.

${ }^{8}$ Part of two CFAF syndicated loans that were signed in April and May 2009 for a total of CFAF 38 billion for the payment of VAT credit arrears and that involved non-Malian banks in the WAEMU and CEMAC CFA franc zones; subsequently resold to Malian banks.

\section{(CInternational Monetary Fund. Not for Redistribution}


Table 3. Mali: Quantitative Performance Criteria and Indicative Targets for $2010^{1}$

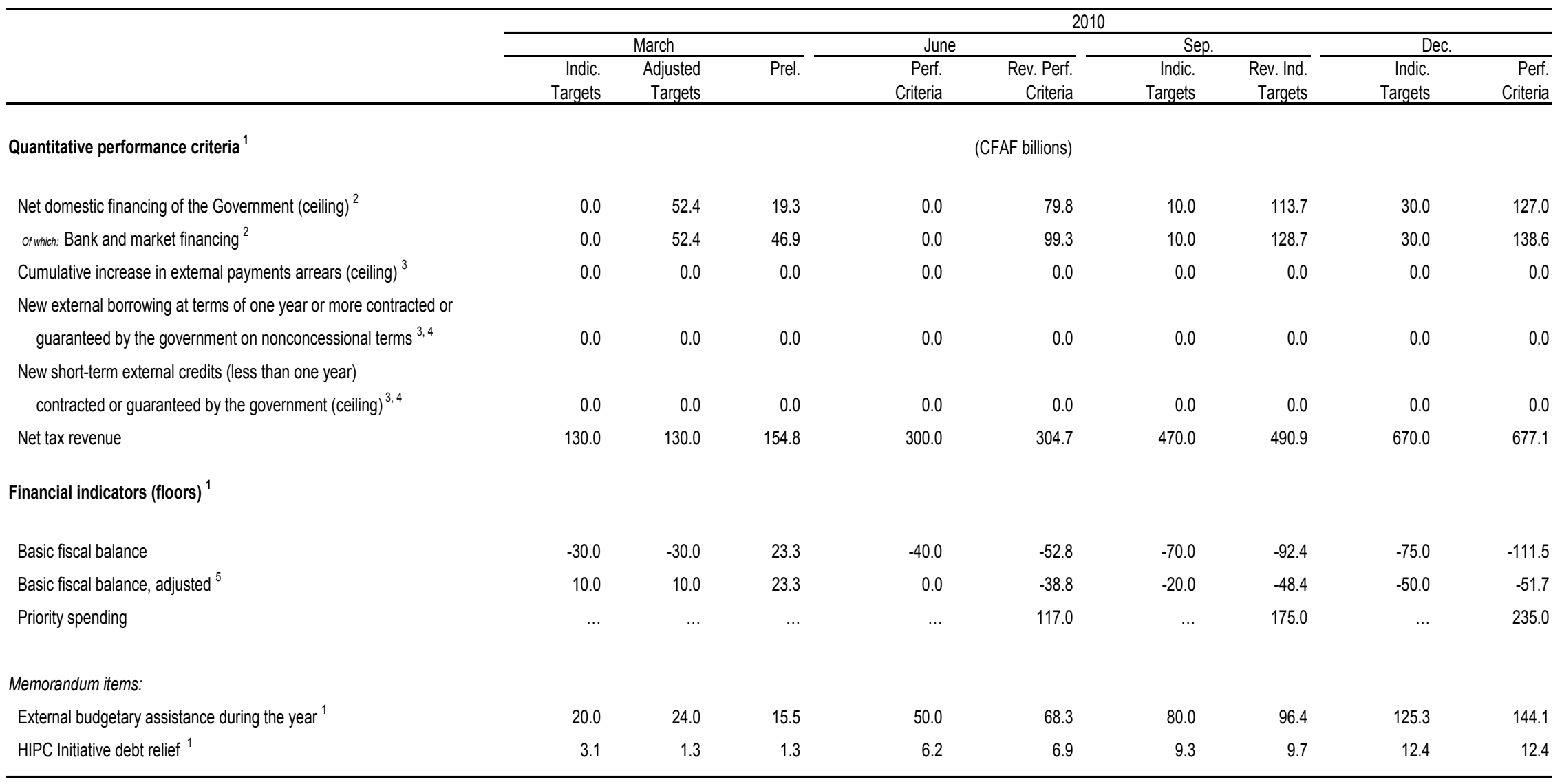

1. Cumulative figures from the beginning of each year. Noncontinuous performance criteria at end-March and end-September 2010 are quantitative benchmarks. See technical memorandum of understandings for definitions.

${ }^{2}$ These performance criteria and benchmarks are subject to adjustors for shorffalls of external budgetary assistance et over/under performance regarding the targeted reduction of pending bills and VAT credits.

The reductions of pending bills are 2.0, 43.7, 48.7 and 49.1 billion of CFAF at end-March, June, September and December 2010, respectively. A reduction of VAT credits by 29.0 billion of CFAF is projected for end-December 2010

${ }^{3}$ These performance criteria will be monitored on a continuous basis.

${ }^{4}$ Grant component equal to or higher than 35 percent.

${ }^{5}$ Excluding expenditures financed with funds from the privatization of SOTELMA. 
Table 4. Mali: Structural Benchmarks for the Third and Fourth Reviews Under the ECF Program

For end-September 2009 (in the context of the 3rd program review)

1 Put in place the tax center for medium-sized enterprises (CIME) and start up its activities.

2 Prepare a government cash flow plan consistent with budget nomenclature (section, economic code) to facilitate (i) quarterly monitoring of budget execution in terms of commitment, validation, payment authorization, and payment of expenditure, and (ii) better alignment of budget execution with available resources.

3 Regarding monitoring of the cotton sector and in consultation with the IMF, prepare a monthly financial plan for the 2009/10 crop season of the financial operations (revenue, commitments, payment, debt, amounts unpaid) of the various participants in the sector(producers, CMDT, suppliers, banks, the government).

4 Regarding government support for the agricultural sector and preparation of the 2010 budget, put in place a dedicated, targeted input subsidization system for grain and cotton crops, including modalities for implementation, followup, and assessment.
Strengthen revenue mobilization.

Observed at endNovember 2009

Strengthen public financial management, budget execution, and treasury management.
Observed at endSeptember 2009
Improve governmence and transparency in Observed at endthe cotton sector with the view to ensuring September 2009 smooth cottn campaign in 2009-2010 and limit budgetary risks.
Increase effectiveness and transparency of agricultural policy, prevent open-ended budgetary contributions and ensure monitoring and evaluation of subsidies.
Observed at endSeptember 2009

\section{For end-December 2009 (in the context of the 4th program review)}

1 On the basis of the evaluation of the budgetary payment float at end-March 2008 by the Auditor General and the evaluation of the payment float at end-March 2009 by the Controller General's Office and the Inspectorate General of Finance, put in place a system to monitor budgetary float supported by improvements in the Treasury's accounting, cash flow management, and information systems, in consultation with IMF staff.

2 By government decision, adopt a strategy and timeframe for government divestment of the Banque de l'Habitat du Mali (BHM).

3 Finalize the government study on the macroeconomic impact of the gold mining sector (balance of payments, growth, employment, budget) and its medium-term prospects.

4 In conjunction with the BCEAO, prepare (i) an exhaustive inventory of the bank accounts taken into account in the net government position, and (ii) an appropriate methodology for recording movements on these accounts, based on an accepted classification (such as projects, correspondents, etc.) in the government flow of funds table (TOFE).
Improve transparency, measurability and management of domestic debt, and prevent occurance of domestic payment arrears.

Increase confidence in and resilience of Observed at endthe banking system, and avoid more costly December 2009 rescue packages.

To help policy and decision making in the context of a declining sector (known reserves are equivalent to 10 years of exploitation).

Improve public finance statistics.

Observed at endDecember 2009
Observed at endDecember 2009
Not observed at endDecember 2009, as a result of decision to implement new public accounting software; monitoring of pending bills continues to be done through the expenditure chain. 
Table 5. Mali: Structural Benchmarks for the Fifth and Sixth Reviews Under the ECF Program

Measures

Macroeconomic rationale

\section{For end-June 2010 (in the context of the fifth program review)}

1 Implement the new expenditure management software PRED5.

To improve budgetary management.

2 Introduce new reporting on the financial operations of the State (the "TOFE" table) which conforms to best international practices, including for the presentation of domestic financing.

To strengthen government statistics and reporting.

3 Create an interministerial committee for treasury management planning under the authority of the Minister of Economy and Finance, with a permanent technical secretariat provided by Treasury.

4 Prepare a draft policy paper on the role of the State in the cotton sector after the privatization of the CMDT.

To improve treasury management and its coordination with budgetary management.

To set the business environment in the cotton sector in a post-privatization of the state monopsony CMDT.

For end-December 2010 (in the context of the sixth program review)

1 Implement a system for the management and timely payment of Value Added Tax (VAT) credits to eligible companies.

2 Produce an evaluation of restructuring of the Housing Bank of Mali (BHM), including the use of State funds transferred to the $\mathrm{BHM}$ in the first half of 2010 to relaunch its lending activities.

3 Elaborate a program for the reform of the tax system, aiming at a greater mobilization of revenue while ensuring greater rationalization and modernization of the tax laws, including through reconsideration of tax exemptions.

4 Implement the new public accounting software in the Treasury with the necessary links to the budget application software to ensure monitoring of spending from commitment to payment, including the stock of pending bills.
To prevent accumulation of VAT credit arrears and ensure neutrality of VAT on exports.

To ensure that the BHM is effectively on a recovery track.

To simplify and make the tax system more buoyant, while implementing regional directives.

To ensure improved recording and reporting of financial operations of the State. 
Attachment I

\section{TEChNiCAL Memorandum OF Understanding}

1. This technical memorandum of understanding defines the performance criteria and benchmarks for the program supported by the Extended Credit Facility (ECF) arrangement. It also sets out the frequency and deadlines for data reporting to the staff of the International Monetary Fund (IMF) for program-monitoring purposes.

\section{DeFinitions}

2. Unless otherwise indicated, the government is defined as the central administration of the Republic of Mali and does not include local administrations, the central bank, or any other public entity with autonomous legal personality that is not included in the table of government financial operations (TOFE).

3. The definitions of "debt" and "concessional loans" for the purposes of this memorandum of understanding are as follows:

(a) Debt is defined in Point 9 of the Decision of the Executive Directors of the IMF No. 12274-00/85 of August 24, 2000, as revised on August 31, 2009 (Decision No. 14416-(09/91).

(b) A loan is considered concessional if, on the date the contract is signed, the ratio of the present value of the debt, based on the reference interest rates, to the nominal value of the debt is less than 65 percent (i.e., a grant element exceeding 35 percent). The reference interest rates used in this assessment are the currency specific commercial interest reference rates (CIRRs) established by the Organization for Economic Cooperation and Development (OECD). For debt with a maturity exceeding 15 years, the ten-year-average CIRR published by the OECD is used to calculate the grant element. For shorter maturities, the six-month average CIRR is used. To both the tenyear and six-month averages, the same margins for differing repayment periods as those used by the OECD need to be added $(0.75$ percent for repayment periods of less than 15 years, 1 percent for 15 to 19 years, 1.15 percent for 20 to 29 years, and 1.25 percent for 30 years or more).

\section{Quantitative Performance Criteria ANd Financial Indicators}

Except as noted, the following financial variables shall constitute performance criteria at end-June and End-December and financial indicators otherwise. The basic fiscal balance is a financial indicator at all test dates. 


\section{A. Ceiling on Net Domestic Financing of the Government; Subceiling on Net Domestic Bank and Market Financing of the Government}

4. Net domestic financing is defined as the sum of (i) net bank credit to government, as defined below, and (ii) nonbank financing of the government.

5. Figures on net bank credit to government are calculated by the BCEAO. Figures on nonbank financing are calculated by the public treasury, and are final in the context of the program.

6. Net bank credit to government is defined as the balance between government debts and government claims vis-à-vis the central bank and commercial banks. The scope of net bank credit to government is that used by the Central Bank of West African States (BCEAO) and is consistent with established Fund practice in this area. It implies a broader definition of government than that specified in paragraph 2 by also including local governments, and selected autonomous government agencies and projects. government claims include the CFA franc cash balance, postal checking accounts, secured liabilities (obligations cautionnées), and all deposits with the BCEAO and commercial banks of public entities, with the exception of industrial or commercial public institutions (EPICs) and public enterprises, which are excluded from the calculation. Government debts to the banking system include all debts to these same financial institutions. Deposits of the cotton stabilization fund and government securities held outside the Malian banking system are not included in the calculation of net bank credit to government.

7. Nonbank financing of the government is defined as nonbank market financing and other nonbank financing. Nonbank market financing includes sales net of repayments of government bills and bonds held outside national banking institutions. Other nonbank financing of the government includes proceeds from the sale of government assets, repayments on domestic debt to nonbank creditors, and other net claims on the treasury. The receipts from sale of government assets are defined as the proceeds from the sale, effectively received by the government during the fiscal year, of all or part of the shares held by the government in privatized enterprises. In the event that payments in respect of these sale transactions are expected to extend beyond the fiscal year, the residual will be included in the calculation of nonbank financing of the government in each of the subsequent years, in accordance with the annual scheduling of the expected payments.

8. Net domestic bank and market financing of the government is defined as the sum of (i) net bank credit to government, as defined above, and (iii) nonbank financing of the government through the issuance of securities to nonbanks or to nonresident banks domiciled within the West African Economic and Monetary Union. 


\section{Adjustment factors}

9. The ceiling on the change in net domestic financing of the government and the subceiling on bank and market financing in 2010 will be adjusted down (up) if external budgetary assistance exceeds (falls short of) the program amount. Budgetary assistance is defined as grants, loans, and debt relief (excluding project loans and grants, IMF resources, and debt relief under the Initiative for Heavily Indebted Poor Countries, but including both general and sectoral budget support). Adjustment will be made at a rate of nil percent for amounts up to CFAF 10 billion; 50 percent for amounts from CFAF 10 billion up to CFAF 25 billion; and 75 percent for amounts in excess of CFAF 25 billion.

10. The ceiling on the change in net domestic financing of the government and the subceiling on bank and market financing in 2010 will be adjusted up (down) if the actual net reduction of the payment float exceeds (falls short) of the programmed amounts (CFAF 43.7 billion at end-June, CFAF 48.7 billion at end-September 2010, and CFAF 49.1 billion at end-December 2010). The payment float is defined to include payment orders unpaid by the Treasury in the context of the budget execution and the deposits of correspondents and various depositors, irrespective of their age. In addition, the ceiling on the change in net domestic financing and the sub-ceiling on bank and market financing in 2010 will be adjusted up for the settlement of VAT credits to exporters that are in excess of the programmed amounts, that is CFAF zero billion at end-June and end-September 2010, and CFAF 29 billion at end-December 2010: the adjustment refers to payments made on VAT credits accrued in 2010 and on the end-2009 stock of CFAF 29 billion.

\section{B. Nonaccumulation of External Public Payments Arrears}

11. External payments arrears are defined as the sum of external payments due and unpaid for external liabilities of the government and foreign debt held or guaranteed by the government. The definition of external debt provided in paragraph 3(a) applies here.

12. Under the program, the government will not accumulate external payments arrears, with the exception of arrears arising from debt under renegotiation or being rescheduled. The performance criterion on the nonaccumulation of external payments arrears will be applied on a continuous basis throughout the program period.

\section{Ceiling on Nonconcessional External Debt with a Maturity of One Year or More Newly Contracted or Guaranteed by the Government and/or Public Enterprises}

13. This performance criterion applies not only to debt as defined in point 9 of the Executive Board Decision No. 12274-(00/85) (8/24/00), as revised on August 31, 2009 (Decision No. 14416-(09/91), but also to commitments contracted or guaranteed for which no value has yet been received. 
14. The concept of government for the purposes of this performance criterion includes government as defined in paragraph 2, administrative public institutions (EPAs), scientific and/or technical public institutions, professional public institutions, industrial and/or commercial public institutions (EPICs), state-owned enterprises, and local governments.

15. Starting on the date of program approval by the Executive Board of the IMF, a ceiling of zero is set for nonconcessional borrowing. This performance criterion is monitored on a continuous basis.

16. The government undertakes not to contract or guarantee external debt with a maturity of one year or more and a grant element of less than 35 percent (calculated using the reference interest rates corresponding to the borrowing currencies provided by the IMF). This performance criterion applies not only to debt as defined in point 9 of the Executive Board Decision No. 12274-(00/85) (8/24/00), as revised on August 31, 2009 (Decision No. 14416(09/91), but also to commitments contracted or guaranteed for which no value has yet been received. However, the criterion does not apply to (i) financing granted by the IMF, (ii) debt rescheduling transactions of debt existing at the time of the approval of the PRGF arrangement, and (iii) CFA franc debt contracted or guaranteed by the government with West African Economic and Monetary Union (WAEMU) residents (including CFA debt initially contracted or guaranteed by the government with WAEMU residents and subsequently acquired by nonresidents).

\section{Ceiling on Short-Term External Debt Newly Contracted or Guaranteed by the Government and/or Public Enterprises}

17. The definition in paragraph 2 and 3 of this TMU applies to this performance criterion. Short-term external debt is debt with a contractual term of less than one year. Import- related credit, CMDT foreign borrowing secured by the proceeds of cotton exports, and debt-relief operations are excluded from this performance criterion. Treasury bills issued in CFA francs on the WAEMU regional market are also excluded. In the context of the program, the government and public enterprises will not contract, or guarantee, short-term external debt. This performance criterion is monitored on a continuous basis.

\section{E. Floor on Cumulative Net Tax Revenues}

18. Government tax revenues are defined as those that figure in the Table on government financial operations (TOFE), and include all tax revenues accruing to the ordinary budget. Net tax revenues are gross tax revenues less tax refunds, notably on VAT. The government shall report cumulative tax revenues from the start of each year to IMF staff each month in the context of the TOFE. 


\section{F. Floor on the Basic Fiscal Balance, Excluding HIPC Initiative-Related Expenditure}

19. The basic fiscal balance is defined as the difference between total revenues, excluding grants and privatization receipts, and total expenditure plus net lending, excluding capital expenditure financed by foreign donors and lenders and HIPC Initiative-related expenditures.

\section{G. Floor on the Basic Fiscal Balance, Excluding HIPC Initiative-Related Expenditure and Expenditures Financed with SOTELMA Privatization Receipts}

20. The basic fiscal balance, excluding HIPC Initiative-related expenditure and expenditures financed with SOTELMA privatization receipts is defined as in section II.F, from which are deducted expenditures financed by SOTELMA privatization revenues.

\section{H. Floor on Priority Poverty-Reducing Expenditures}

21. Priority poverty-reducing expenditures are defined as the total of current expenditures of the Ministry of Primary Education; the Ministry of Secondary and Higher Education and Scientific Research; and the Ministry of Health. Current Expenditures are defined as expenditures on personnel, goods and services, transfers, and other current spending, including those labeled HIPC Initiative. It excludes spending on equipment and investment, whether financed domestically or externally, and expenditures financed with sectoral budget support.

\section{STRUCtural Measures}

22. Information relating to the introduction of the measures constituting structural benchmarks and performance criteria will be sent to Fund staff within two weeks of the date of their scheduled implementation.

\section{AdDitional Information For Program Monitoring}

23. The government will provide IMF staff with information as set out in the following summary table in order to assist in the monitoring of the program. 


\section{SUMMARY OF DATA TO BE REPORTED}

\begin{tabular}{|c|c|}
\hline Data Type & Tables \\
\hline \multirow[t]{3}{*}{ Real sector } & National accounts \\
\hline & Revisions of the national accounts \\
\hline & Disaggregated consumer price indexes \\
\hline \multirow[t]{4}{*}{$\begin{array}{l}\text { Government } \\
\text { finances }\end{array}$} & $\begin{array}{l}\text { Net government position (including the list of } \\
\text { accounts of other public entities with the banking } \\
\text { system) and breakdown of nonbank financing }\end{array}$ \\
\hline & $\begin{array}{l}\text { Balance of SOTELMA privatization receipts on } \\
\text { deposit at the BCEAO }\end{array}$ \\
\hline & Treasury general ledger \\
\hline & $\begin{array}{l}\text { TOFE of the central government and consolidated } \\
\text { TOFE }\end{array}$ \\
\hline
\end{tabular}

Budget execution through the expenditure chain as recorded in the automated system

Breakdown of fiscal revenue and expenditure in the context of the TOFE

Separate report on outlays financed with HIPC resources

Execution of capital budget

Execution of SOTELMA spending

Tax revenues in the context of the TOFE

Wage bill in the context of the TOFE

Basic fiscal balance in the context of the TOFE

Regulatory order setting prices of petroleum

products, tax revenues from petroleum products, and subsidies paid

Imports of petroleum products by type and point of entry

Customs exemptions

Treasury operations of the CMDT

Monetary and Summary accounts of the BCEAO, summary

financial data accounts of banks, and accounts of the banking system

Foreign assets and liabilities and other items net of Monthly the BCEAO and the commercial banks.
Frequency Time Frame

Annual End of year +9 months

Variable 8 weeks following the revision

Monthly End of month +2 weeks

Monthly End of month +3 weeks (provisional); end of month +6 weeks (final)

Monthly End of month +3 weeks

Monthly End of month +4 weeks

Monthly End of month +3 weeks (provisional); end of month +6 weeks (final)

Monthly End of month +2 weeks

Monthly End of month +6 weeks (TOFE)

Monthly End of month +6 weeks

Quarterly End of quarter +8 weeks

Quarterly End of quarter +8 weeks

Monthly End of month +6 weeks

Monthly End of month +6 weeks

Monthly End of month +6 weeks

Monthly End of month

Monthly End of month +2 weeks

Monthly End of month +4 weeks

Monthly End of month +4 weeks

Monthly End of month +4 weeks (provisional); end of month +8 weeks (final)

End of month +8 weeks 


\begin{tabular}{|c|c|c|c|}
\hline Data Type & Tables & Frequency & Time Frame \\
\hline & $\begin{array}{l}\text { Lending and deposit interest rates, BCEAO } \\
\text { intervention rates, and BCEAO reserve } \\
\text { requirements }\end{array}$ & Monthly & End of month +4 weeks \\
\hline & Bank prudential ratios & Monthly & End of month +6 weeks \\
\hline \multirow{2}{*}{$\begin{array}{l}\text { Balance of } \\
\text { payments }\end{array}$} & Balance of payments & Annual & End of year +12 months \\
\hline & Revisions of balance of payments & Variable & $\begin{array}{l}8 \text { weeks following each } \\
\text { revision }\end{array}$ \\
\hline \multirow[t]{2}{*}{ External debt } & Breakdown of all new external borrowing terms & Monthly & End of month +4 weeks \\
\hline & $\begin{array}{l}\text { Debt service, indicating amortization, interest } \\
\text { payments, and relief obtained under the HIPC } \\
\text { Initiative }\end{array}$ & Monthly & End of month +4 weeks \\
\hline \multirow[t]{6}{*}{ PRSP } & Share of poverty-reducing expenditure & Quarterly & End of quarter +4 weeks \\
\hline & $\begin{array}{l}\text { Share of primary education in total education } \\
\text { outlays }\end{array}$ & Quarterly & End of quarter +4 weeks \\
\hline & $\begin{array}{l}\text { Gross enrollment ratio in primary education, by } \\
\text { gender }\end{array}$ & Annual & $\begin{array}{l}\text { Beginning of the next } \\
\text { academic year }+1 \text { month } \\
\text { (final) }\end{array}$ \\
\hline & $\begin{array}{l}\text { Percentage of the population having access to } \\
\text { health care facilities within a radius of } 15 \\
\text { kilometers }\end{array}$ & Annual & End of year +2 months \\
\hline & Rate of assisted births & Annual & End of year +2 months \\
\hline & $\begin{array}{l}\text { Data on immunization rate DTCP } 3 \text { of child below } \\
1 \text { year }\end{array}$ & Annual & End of year +2 months \\
\hline
\end{tabular}


INTERNATIONAL MONETARY FUND

MALI

STAFF REPORT FOR THE 2010 ARTICLE IV CONSULTATION, FOURTH REVIEW UNDER THE THREE-YEAR ARRANGEMENT UNDER THE EXTENDED CREDIT FACILITY, AND Request for Modification of Performance Criteria

\section{Informational Annex}

Prepared by the African Department

(In collaboration with other departments)

Approved by Roger Nord and Thomas Dorsey

June 29, 2010

- Relations with the Fund. Describes financial and technical assistance from the Fund and provides information on the safeguards assessment and exchange rate system. Outstanding purchases and loans amounted to SDR 29.99 million (32.1 percent of quota) at end-May, 2010.

- Relations with the World Bank. Describes the World Bank Group program and portfolio, including collaboration with the Fund.

- Statistical Issues. Assesses the quality of statistical data. Data provision for surveillance purposes is adequate overall, but weaknesses in a broad range of economic statistics are hampering the analyses of economic developments. 


\section{Contents}

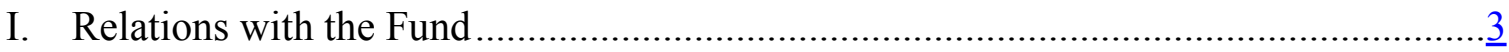

II. Relations with the World Bank Group .................................................................

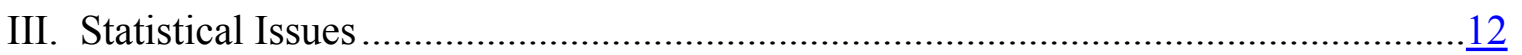




\section{Mali: Relations With THE FUND}

(As of May 31, 2010)

1. Membership Status: Joined September 27, 1963

Article VIII

2. General Resources Account

Quota

SDR Millions

93.30

$\%$ Quota

83.36

100.00

Fund holdings of currency

9.96

89.34

Reserve position

10.68

Holdings Exchange Rate

3. SDR Department

Net cumulative allocation

Holdings

4. Outstanding Purchases and Loans

ECF arrangements
SDR Millions

89.36

73.37

SDR Millions

29.99
\%Allocation

100.00

82.10

\%Quota

32.14

\section{Latest Financial Arrangements}

Approval Expiration

Type

$\mathrm{ECF}^{1}$

Date

ECF

May 28, 2008

$\underline{\text { Date }}$

ECF Jun 23, 2004

May 27, 2011

Aug 06, 1999

Aug 05, 2003

Amount Approved

Amount Drawn

(SDR Millions)

27.99

9.33

21.99

51.32

1/ Formerly PRGF.

\section{Projected Payments to Fund}

(SDR million; based on existing use of resources and present holdings of SDRs):

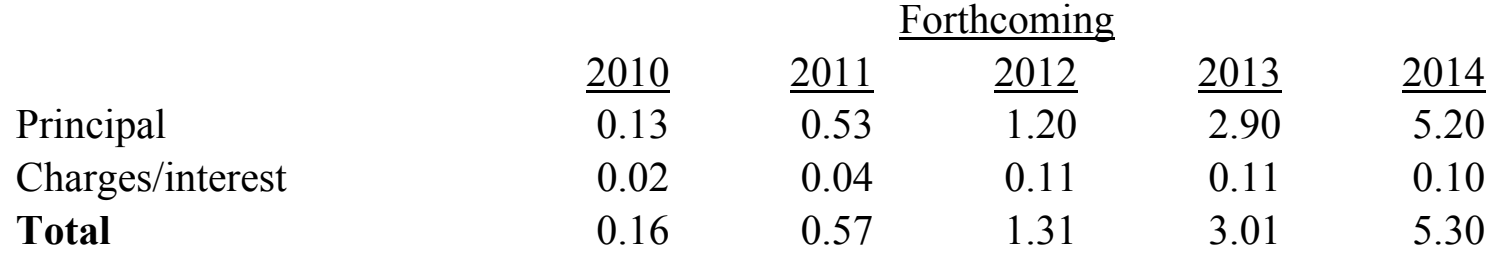


7. Implementation of HIPC Initiative

I. Commitment of HIPC assistance

Decision point date

Assistance committed

by all creditors (US $\$$ millions) ${ }^{1}$

Of which: IMF assistance (US\$ millions)

(SDR equivalent in millions)
Original

Framework

Sep 1998

121.00

14.00

10.80

Sep 2000

Original

Framework
Enhanced

Framework

Sep 2000

417.00

45.21

34.74

Mar 2003

Enhanced

Framework $\quad \underline{\text { Total }}$

II. Disbursement of IMF assistance (SDR millions)

$\begin{array}{lrrr}\text { Assistance disbursed to the member } & 10.80 & 34.74 & 45.54 \\ \quad \text { Interim assistance } & -- & 9.08 & 9.08 \\ \text { Completion point balance } & 10.80 & 25.66 & 36.46 \\ \text { Additional disbursement of interest income }{ }^{2} & -- & 3.73 & 3.73 \\ \quad \text { Total disbursements } & 10.80 & 38.47 & 49.27\end{array}$

\footnotetext{
${ }^{1}$ Assistance committed under the original framework is expressed in net present value (NPV) terms at the completion point, and assistance committed under the enhanced framework is expressed in NPV terms at the decision point. Hence these two amounts cannot be added.

${ }^{2}$ Under the enhanced framework, an additional disbursement is made at the completion point corresponding to interest income earned on the amount committed at the decision point but not disbursed during the interim period.
}

Decision point — point at which the IMF and the World Bank determine whether a country qualifies for assistance under the HIPC initiative and decide on the amount of assistance to be committed.

Interim assistance - amount disbursed to a country during the period between decision and completion points, up to 20 percent annually and 60 percent in total of the assistance committed at the decision point (or 25 percent and 75 percent, respectively, in exceptional circumstances).

Completion point - point at which the country receives the remaining balance of its assistance committed at the decision point, together with an additional disbursement of interest income as defined in footnote 2 above. The timing of the completion point is linked to the implementation of pre-agreed key structural reforms (i.e., floating completion point). 


\title{
8. Implementation of Multilateral Debt Relief Initiative (MDRI)
}

$\begin{array}{cc}\text { I. MDRI-eligible debt (SDR million) }^{1} & 75.07 \\ \text { Financed by: MDRI Trust } & 62.44 \\ \text { Remaining HIPC resources } & 12.63\end{array}$

II. Debt Relief by Facility (SDR million)

Delivery Date: January 2006

\begin{abstract}
${ }^{1}$ The MDRI provides 100 percent debt relief to eligible member countries that qualify for the assistance. Grant assistance from the MDRI Trust and MDRI Trust and HIPC resources provide debt relief to cover the full stock of debt owed to the Fund as of end-2004 that remains outstanding at the time the member qualifies for such debt relief.
\end{abstract}

\section{Safeguards Assessments}

The Central Bank of West African States (BCEAO) is a common central bank of the countries of the West African Economic and Monetary Union (WAMU). The most recent safeguards assessment of the BCEAO was completed on March 1, 2010. The 2010 update assessment found that the BCEAO continues to have controls in place at the operational level. The overall governance framework should nonetheless be strengthened by the addition of an audit committee to ensure that the Board of Directors exercises appropriate oversight over the control structure, including the audit mechanisms and financial statements. The completion of the Institutional Reform of the WAMU and the BCEAO in the beginning of 2010 should help to correct that situation. Efforts to implement fully the International Financial Reporting Standards reporting framework should also be pursued.

\section{Exchange Rate Arrangements}

Mali is a member of the West African Economic and Monetary Union (WAEMU). The exchange system, common to all members of the union, has no restrictions on the making of payments and transfers for current international transactions. The union's common currency, the CFA franc, was pegged to the French franc at the rate of CFAF 50=FF 1 from 1948 until early 1994. Effective January 12, 1994, the CFA franc was devalued, and the new parity set at CFAF $100=$ FF 1 . Effective January 1, 1999, the CFA franc was pegged to the Euro at a rate of CFAF $655.96=$ EUR 1 .

As of June 1, 1996, Mali and other members of WAEMU accepted the obligations of Article VIII, Sections 2, 3, and 4 of the Fund's Articles of Agreement. Mali's exchange 
system has no restrictions on making payments or transfers for current international transactions and the country does not engage in multiple currency practices.

Sharing a common trade policy with other members of WAEMU, Mali has shifted key trade policy-making to the sub-regional level. The common external tariff (CET) was adopted in January 2000. Mali complies with the union's tariff rate structure and has effectively dismantled internal tariffs. Between 1997 and 2003, WAEMU tariff reform reduced the simple average custom duty from 22 percent to 15 percent; the maximum rate is currently 20 percent. Imports to Mali are not subject to quantitative restrictions.

Mali's exports to the European Union generally enjoy non-reciprocal preferential treatment in the form of exemption from import duties under the Everything but Arms initiative.

Malian goods enjoy nonreciprocal preferential access to the markets of developed countries other than the European Union under the Generalized System of Preferences. Mali is also eligible to benefits from the United States' African Growth and Opportunity Act. Mali imposes no de jure restrictions on exports.

\section{Article IV Consultations}

Mali's Article IV consultation cycle is governed by the provisions of the July 2002 decision on consultation cycles. The Executive Board completed the 2008 Article IV consultation (EBS/08/52) on May 28, 2008.

\section{Technical Assistance}

\begin{tabular}{llll}
\hline Department & $\begin{array}{l}\text { Type of } \\
\text { Assistance }\end{array}$ & $\begin{array}{l}\text { Time of } \\
\text { Delivery }\end{array}$ & Purpose \\
\hline MCM & Staff & Apr 2010 & Public Debt Management \\
FAD & Expert & Apr 2010 & Fiscal Administration \\
FAD & Expert & Mar 2010 & Expenditure administration \\
FAD & Expert & Jun 2009 & Tax Administration \\
FAD & Expert & Nov 2008 & Help establish medium-size taxpayer unit \\
FAD & Expert & Oct 2008 & Assist Treasury computerization \\
AFRITAC & Expert & Sep 2008 & Prepare the source data for the 2006 national \\
& & accounts \\
STA & Staff & Jul 2008 & Advance GFS 2001 implementation \\
AFRITAC & Expert & Jun 2008 & Strengthen microfinance supervision in Mali \\
AFRITAC & Expert & Jun 2008 & Strengthen real sector statistics in Mali
\end{tabular}




\begin{tabular}{|c|c|c|c|}
\hline FAD & Staff & Apr 2008 & Strengthening of public accounts \\
\hline FAD & Expert & Mar 2008 & Establishment of medium-size taxpayer unit \\
\hline FAD & Staff & Feb 2008 & Customs administration \\
\hline AFRITAC & MFI Expert & Nov 2007 & Control of microfinance institution. \\
\hline AFRITAC & $\begin{array}{l}\text { Customs } \\
\text { expert }\end{array}$ & Nov 2007 & $\begin{array}{l}\text { Customs control procedures, and ways to speed up } \\
\text { customs clearances }\end{array}$ \\
\hline AFRITAC & $\begin{array}{l}\text { Statistics } \\
\text { Advisor }\end{array}$ & Nov 2007 & $\begin{array}{l}\text { Help in ensuring consistency of national accounts } \\
\text { data, and checks in national accounts }\end{array}$ \\
\hline AFRITAC & MFI Advisor & Sep 2007 & Control of microfinance institutions \\
\hline $\begin{array}{l}\text { FAD/ } \\
\text { AFRITAC }\end{array}$ & Staff & Sep 2007 & $\begin{array}{l}\text { Modernization of tax administration and strategy for } \\
\text { the next stage of reforms, with focus on priority } \\
\text { measures to improve the performances of the tax } \\
\text { department }\end{array}$ \\
\hline AFRITAC & $\begin{array}{l}\text { Statistics } \\
\text { Advisor }\end{array}$ & $\begin{array}{l}\text { Jun-Jul } \\
2007\end{array}$ & Migration to SNA 1993 \\
\hline AFRITAC & $\begin{array}{l}\text { PEM } \\
\text { Advisor and } \\
\text { expert }\end{array}$ & Jul 2007 & $\begin{array}{l}\text { National Treasury's accounting and centralization of } \\
\text { accounts }\end{array}$ \\
\hline $\begin{array}{l}\text { STA/ } \\
\text { AFRITAC }\end{array}$ & Staff & Jul 2007 & $\begin{array}{l}\text { Use of GFSM } 2001 \text { framework for fiscal policy } \\
\text { analysis }\end{array}$ \\
\hline AFRITAC & $\begin{array}{l}\text { Statistics } \\
\text { Advisor }\end{array}$ & Mar 2007 & Gold statistics \\
\hline AFRITAC & Debt Advisor & Mar 2007 & $\begin{array}{l}\text { External debt computerization(follow up on } 2006 \\
\text { mission) }\end{array}$ \\
\hline AFRITAC & $\begin{array}{l}\text { PEM } \\
\text { Advisor and } \\
\text { expert }\end{array}$ & Aug 2006 & Computerization of budget operations \\
\hline AFRITAC & STA Advisor & Jul 2006 & Workshop on the GFS compilation \\
\hline AFRITAC & STA Advisor & Jun 2006 & Gold statistics \\
\hline AFRITAC & Expert & Apr 2006 & Fuel pricing and taxation \\
\hline AFRITAC & STA Advisor & Mar 2006 & $\begin{array}{l}\text { Strategy for developing national accounts and } \\
\text { consumer price statistics }\end{array}$ \\
\hline AFRITAC & STA Advisor & Mar 2006 & Statistics for gold sector \\
\hline AFRITAC & $\begin{array}{l}\text { Customs } \\
\text { Advisor }\end{array}$ & Mar 2006 & Customs valuation \\
\hline
\end{tabular}




$\begin{array}{llll}\text { AFR/FAD } & \text { Staff } & \text { Feb 2006 } & \begin{array}{l}\text { Wage policy } \\ \text { AFRITAC }\end{array} \\ \text { MFI Advisor } & \text { Sep 2005 } & \begin{array}{l}\text { Help CAS/SFD to improve its function, control, and } \\ \text { inspection capacity }\end{array} \\ \text { AFRITAC } & \begin{array}{l}\text { PEM } \\ \text { Advisor and } \\ \text { expert }\end{array} & \text { Aug 2005 } & \text { Treasury accounting } \\ \text { LEG } & \text { Expert } & \text { Aug 2005 } & \text { Anti-money-laundering law }\end{array}$




\section{MALi: Relations With THE WORLD BANK GROUP \\ (May, 2010)}

\section{A. Partnership in Mali's development strategy}

1. Mali's Growth and Poverty Reduction Strategy Framework (GPRSF), adopted by the Government in December 2006, comprises programs over the 2007-11 period grouped under the following three pillars: (i) infrastructure development and strengthening of the productive sectors (including food security, rural development, SME development, and sustainable natural resources management); (ii) strengthening of the structural reform agenda (comprising public sector reforms, investment climate, financial sector, governance, and capacity of the civil society); and (iii) strengthening of social sector services (including promotion of job creation, improved access to basic social services, and HIV/AIDS).

2. The IMF and World Bank staffs maintain a collaborative relationship in supporting the Government's macroeconomic and structural reforms, in line with the guidelines for enhanced Bank-Fund collaboration. This includes participation of Bank staff in the meetings with the Malian authorities on the Fund's program review missions, and IMF staff participation in Bank development policy missions as well as in Bank internal review meetings on key operations or studies. The IMF takes the lead in macroeconomic stabilization and the World Bank in social and structural areas, with close collaboration on a few structural areas that have a particular impact on macroeconomic stability. The Fund's dialogue and conditionality are consistent with the structural programs agreed with the Bank, and the Bank's policy framework with Mali is consistent with the Government's macroeconomic framework agreed with the Fund.

\section{B. World Bank Group strategy}

3. The World Bank Group's strategy, outlined in the joint IDA-IFC Country Assistance Strategy (CAS) discussed by the Board of Directors on February 5, 2008, selectively supports key pillars of the 2006 GPRSF. The CAS covers the period FY08-11 and has two strategic objectives: (i) promote rapid and broad-based growth; and (ii) strengthen public sector performance for service delivery. Within the two CAS pillars, the Bank will focus on (a) private sector led growth by addressing key constraints such as productivity, energy, transport, and finance and by linking the country to the rest of the world; (b) governance; and (c) capacity development. The Bank also supports Mali under the Bank's Regional Integration Assistance Strategy (2001), notably the programs for connection to the West Africa Power Pool, harmonization of country policies and/or regulatory frameworks (telecommunications, agriculture, and financial sectors), water resource development of the Niger and Senegal Rivers, strengthening of road transport corridors and transit facilitation, and strengthening the regional payments system. The Bank's assistance to Mali in its support to regional integration will be fully aligned with the regional PRS and WAEMU regional

\footnotetext{
${ }^{7}$ This note is updated on an annual basis by World Bank staff.
} 
economic program (REP) priorities.

4. As of May 2010, the IDA portfolio in Mali consists of 9 operations totaling $\$ 526.05$ million in net commitments, of which $\$ 306$ million (58 percent) remain undisbursed. Including the regional operations, the portfolio amounts to $\$ 712.24$ million. About 36 percent of the IDA portfolio is concentrated in the energy sector. The FY08-FY11 CAS envisages yearly PRSCs and self-standing investments in key projects in the energy, agriculture and urban sectors. The second series of PRSCs (PRSC-3 to PRSC-5) was introduced in FY09. The second operation of the series is scheduled for Board consideration on June 1, 2010, for an amount of SDR 46.5 (US\$70.5 equivalent), including SDR 10.3 million (US $\$ 15.5$ equivalent) in Pilot Crisis Response Window resources.

5. Recently completed non-lending activities include a Public Expenditure Management and Financial Accountability Review (PEMFAR); a study on Mali Population and Development; a Mali Education Diagnosis for the Third Investment program for the Education Sector, a study on Skills Development, a study on Mali Safety Nets, and two studies on the impact of the food crisis namely "Assessing the Potential Impact on Poverty of Rising Cereals Prices" and "Impact of Rising Rice Prices and Policy Responses in Mali: Simulations with a Dynamic CGE Model". Ongoing non-lending activities include a series of notes on growth, and an Investment Climate Assessment. The Bank is also supporting the preparation of the second Public Expenditure and Financial accountability (PEFA) report and a household survey. The FY11 indicative knowledge program includes a growth note on mining, a country environmental assessment, and poverty notes.

\section{IMF-World Bank collaboration}

6. Areas in which the Fund leads. The Fund takes the lead in macroeconomic stabilization including macro-fiscal policy, monetary policy, exchange rate policy, and financial stability and risk management.

7. Areas in which the Bank leads. The Bank takes the lead in structural areas where both institutions have conditionality, including cotton sector reform, privatization and regulatory reform (financial and mining sectors). The Bank also leads in other areas such as: agricultural competitiveness/diversification and rural development; private sector development; urban development; transportation policy/infrastructure; energy sector reforms; and social sectors (health, education, social protection, and population issues). The Bank's work in structural areas includes lending operations, analytical work and economic and social policy dialogue. The Bank collaborates closely with other donors in all areas of its sector dialogue with Mali. Harmonized donor support is established in some sections (health, education, Office du Niger, cotton, budget) and is being established in other sectors, namely rural water supply and sanitation.

8. Areas of shared responsibility. Both Bank and Fund monitor progress on budgetary and public expenditure management, yet emphasize different aspects of the Government's reform program in the respective support operations to Mali. The Bank emphasis in this area is on strengthening all phases of the public expenditure system - budget preparation, execution, and controls - to support the Government's objectives of progressive shift toward 
result-based budgeting and improved expenditure management. Bank support is at the national level in the finance ministry (Medium Term Budget Frameworks, procurement, budget reporting, auditing, and information technology system) and sector ministries (selected sector MTEFs, inter- and intra-sectoral allocations), as well as at de-concentrated and decentralized levels of government (IT system, capacity building, auditing, participatory monitoring and evaluation). The Fund's emphasis is on fiscal management, expenditure management (including financing of transfers to parastatals), revenue enhancing measures, and audit capabilities. Table 1 summarizes the areas of Bank-Fund collaboration in Mali. 
Table 1. Bank-Fund Collaboration in Mali (ongoing or planned)

\begin{tabular}{|c|c|c|c|}
\hline Area & $\begin{array}{l}\text { Specialized Advice } \\
\text { from Fund }\end{array}$ & $\begin{array}{l}\text { Specialized Advice from } \\
\text { Bank }\end{array}$ & Key Instruments \\
\hline $\begin{array}{l}\text { Economic } \\
\text { Framework/ } \\
\text { Management }\end{array}$ & $\begin{array}{l}\text { Fiscal/monetary policy, } \\
\text { economic statistics. }\end{array}$ & Economic growth analysis. & $\begin{array}{l}\text { IMF: ECF performance criteria } \\
\text { and benchmarks on fiscal and } \\
\text { monetary targets; technical } \\
\text { assistance. } \\
\text { Bank: PRSC program; analytical } \\
\text { work, economic monitoring. }\end{array}$ \\
\hline $\begin{array}{l}\text { Budget } \\
\text { Framework and } \\
\text { Public Finance } \\
\text { Reforms }\end{array}$ & $\begin{array}{l}\text { Overall budget } \\
\text { envelope, expenditure } \\
\text { management, } \\
\text { enhancement of tax and } \\
\text { non-tax revenue, } \\
\text { pension reform. }\end{array}$ & $\begin{array}{l}\text { Sector MTEFs, institutional } \\
\text { framework for improved } \\
\text { procurement, integrated } \\
\text { information system, } \\
\text { monitoring of budget } \\
\text { execution, efficiency of public } \\
\text { expenditures, fiduciary } \\
\text { accountability and } \\
\text { management, pension reform. }\end{array}$ & $\begin{array}{l}I M F \text { : ECF performance criteria } \\
\text { and benchmarks on overall fiscal } \\
\text { balance, customs exemptions and } \\
\text { taxation of oil products; technical } \\
\text { assistance. } \\
\text { Bank: PRSC program; } \\
\text { Governance and Budget } \\
\text { Decentralization TA, analytical } \\
\text { work. }\end{array}$ \\
\hline $\begin{array}{l}\text { Agriculture and } \\
\text { Rural } \\
\text { Development }\end{array}$ & $\begin{array}{l}\text { Effectiveness and } \\
\text { transparency of } \\
\text { agricultural policy, } \\
\text { framework for } \\
\text { subsidies. }\end{array}$ & $\begin{array}{l}\text { Rural development strategy, } \\
\text { agricultural productivity and } \\
\text { diversification, subsidy policy, } \\
\text { cotton reform to improve the } \\
\text { performance of the sector } \\
\text { under private management } \\
\text { and strengthen farmers' role in } \\
\text { sector management. }\end{array}$ & $\begin{array}{l}I M F \text { : ECF benchmark on reforms } \\
\text { in cotton sector and on subsidies. } \\
\text { Bank: PRSC program; } \\
\text { Agricultural Services and } \\
\text { Producer Organizations project; } \\
\text { Agriculture Diversification and } \\
\text { Competitiveness project; }\end{array}$ \\
\hline $\begin{array}{l}\text { Mining Sector } \\
\text { Development }\end{array}$ & $\begin{array}{l}\text { Mining policy in the } \\
\text { context of a declining } \\
\text { sector. }\end{array}$ & $\begin{array}{l}\text { Transparency in extractive } \\
\text { industries. Development of the } \\
\text { mining sector. }\end{array}$ & $\begin{array}{l}I M F \text { : ECF benchmark on the gold } \\
\text { mining sector. } \\
\text { Bank: PRSC program; Growth } \\
\text { Support project. (GSP) }\end{array}$ \\
\hline $\begin{array}{l}\text { Private Sector } \\
\text { Development }\end{array}$ & $\begin{array}{l}\text { Framework for } \\
\text { increased confidence in } \\
\text { and resilience of the } \\
\text { banking system. }\end{array}$ & $\begin{array}{l}\text { Strategy, policy and } \\
\text { investment program in key } \\
\text { growth-oriented sectors } \\
\text { (telecommunications, } \\
\text { banking, energy, urban } \\
\text { development, transport } \\
\text { services and transit } \\
\text { facilitation), and on business } \\
\text { development. }\end{array}$ & $\begin{array}{l}\text { IMF: ECF benchmarks on the } \\
\text { BHM privatization process. } \\
\text { Bank: PRSC growth component; } \\
\text { GSP; Energy Support Project, } \\
\text { Household energy project; 2nd } \\
\text { West Africa Power Pool project; } \\
\text { Regional Transit Facilitation } \\
\text { project; Regional Air Travel } \\
\text { Security project. }\end{array}$ \\
\hline $\begin{array}{l}\text { Infrastructure } \\
\text { and Other Sectors }\end{array}$ & & $\begin{array}{l}\text { Strategy, policy and } \\
\text { investment program } \\
\text { (transport, energy, health, } \\
\text { water). }\end{array}$ & $\begin{array}{l}\text { Bank: Transport Corridor project; } \\
\text { Agriculture Diversification and } \\
\text { Competitiveness project; } \\
\text { Household Energy and Universal } \\
\text { Access project; 2nd Transport } \\
\text { Sector project (FY07); WAPP; } \\
\text { APL } 2 \text { Regional Water project } \\
\text { (Senegal iver basin development, } \\
\text { and Electricity generation). }\end{array}$ \\
\hline $\begin{array}{l}\text { Human } \\
\text { Development } \\
\text { Reforms/Poverty } \\
\text { Monitoring }\end{array}$ & $\begin{array}{l}\text { Monitoring the GPRSF } \\
\text { in the context of the } \\
\text { annual progress reports. }\end{array}$ & $\begin{array}{l}\text { Reforms in education and } \\
\text { health, HIV/AIDS program, } \\
\text { safety nets, population and } \\
\text { development. Monitoring the } \\
\text { GPRSF in the context of the } \\
\text { annual progress reports. }\end{array}$ & $\begin{array}{l}\text { Bank: Education sector } \\
\text { expenditure program; HIV/AIDS } \\
\text { MAP project, PRSC program, } \\
\text { analytical work on health and } \\
\text { safety net. }\end{array}$ \\
\hline
\end{tabular}

Prepared by World Bank staff. Questions may be referred to Mr. Habib Fetini (Country Director, 33-859-4111) or Ms. De Sousa (Sr. Economist, 473-2558) 


\section{Mali: Statistical Issues}

(As of April 30, 2010)

Data provision has some shortcomings, but is broadly adequate for surveillance. Mali has been participating in the General Data Dissemination System (GDDS) since September 2001 and has advanced the implementation of its short- and medium-term plans for improvement. The metadata has been posted on the Dissemination Standards Bulletin Board (DSBB), since June 2003.

\section{Real sector}

The economic accounts of Mali are prepared by the National Directorate of Statistics and Data Processing (DNSI), in accordance with the System of National Accounts 1968 (SNA68) and adapted to certain characteristics specific to Mali. They are compiled on an annual basis. There are, however, weaknesses in the accuracy, coverage, and timeliness of national accounts data. The main reason has been the inadequacy of source data, along with insufficient funding and technical staffing of the DNSI. The work on implementing the System of National Accounts 1993 (1993 SNA) is ongoing, with the support of the West African Economic and Monetary Union (WAEMU) Commission and AFRITAC West. At this time, the new base year, 2006, has been completed, and 2007 is near completion. It is expected that a new national accounts series spanning 1997-2006 will be available by October 2010.

In concert with other WAEMU member countries, the DNSI has been compiling and publishing a harmonized consumer price index (CPI) for Bamako on a monthly basis since early 1998.

\section{Government finance statistics}

As part of the process of economic integration among the member countries of the WAEMU, the country has made significant progress in bringing its fiscal data in line with the common framework that has been developed with technical assistance from the Fund (the harmonized table of government financial operations - TOFE). However, further efforts are needed to improve the timeliness and coverage of the TOFE. Work is progressing with the assistance of STA, AFRITAC West and AFRISTAT to expand the coverage of the TOFE to public agencies and local governments, as well as to strengthen coverage of domestic financing items. Quarterly budget execution reports are posted on the Ministry of Finance website on a timely basis.

In July 2007, a GFS mission visited Bamako to advance further the implementation of the Government Finance Statistics Manual 2001, and subsequently a country page was introduced in the 2007 issue of GFS Yearbook. To date the authorities have supplied six years of annual GFS data and they are preparing to disseminate quarterly data to STA for 
publication in IFS. In January 2008, the Minister of Finance issued a decree committing the government to the development of a database which will facilitate the balance sheet approach to analysis of the public sector; among the first steps will be an inventory and appraisal of the fair market value of nonfinancial assets. In July 2008, STA AFRITAC West staff visited Bamako for a short follow-up mission and was provided with complete data on both social security agencies.

Public debt statistics are prepared and monitored by separate agencies: external debt by the National Public Debt Directorate (NPDD) and domestic debt by the National Directorate of the Treasury and Government Accounting. The NPDD uses CS-DRMS accounting software. Debt data and projections are of generally good quality, although there is scope for improving presentation as well as the coverage of debt relief (multilateral and bilateral). A Debt Management Performance Assessment (DeMPA) was finalized in late 2009, and the authorities are working to strengthen debt data in line with the DeMPA report's recommendations.

\section{Monetary data}

\section{Monetary and financial statistics:}

Monetary and financial statistics, compiled and disseminated by the regional Central Bank of West African States (BCEAO), are broadly adequate and their institutional coverage is comprehensive. The dissemination of monthly monetary data from the BCEAO takes four to six weeks consistent with GDDS recommendations. Data are posted on the BCEAO website with a considerably longer lag. Accuracy is somewhat hampered by the use of 1990 sorting coefficients to estimate cross border amounts of banknotes among BCEAO countries, which in turn are used to estimate currency in circulation and to adjust the net foreign assets of each member country. Standardized Report Forms (in line with the Monetary and Financial Statistical Manual) are still not regularly used to report monetary data to the IMF.

\section{Balance of payments}

In December 1998, the responsibility for compiling and disseminating balance of payments statistics was formally assigned to the BCEAO by area-wide legislation adopted by the countries participating in the WAEMU. The BCEAO national agency finalizes the data toward mid-November of the following year, and publishes immediately thereafter in the form of a brochure, which however are not sufficiently robust.

In general, the external sector statistics in Mali exhibit serious deficiencies. Concepts and definitions used to compile the balance of payments statistics are in broad conformity with the guidelines presented in the fifth edition of the Balance of Payments Manual (BPM5). The adoption of BPM6 methodology is not required before 2013/2014, except for the recording of SDR allocations as debt liabilities. The Mali balance of payments metadata should also be updated. 
The BCEAO set up a subregional unit responsible for reconciling intra-WAEMU trade data, which is responsible for harmonizing the bilateral statistics of member states to eliminate asymmetries before these data on internal transactions in the Union are consolidated to prepare the WAEMU regional balance of payments. The corrections made are retroactive to national data and help to improve them.

Balance of payments data remain weak in a number of key areas. Data on remittances, foreign direct investment and portfolio flows are similarly weak. Project aid is currently classified as current transfers rather than in the capital account, and several large in-kind projects are not captured in the balance of payments data properly.

Data on international investment position is published in IFS and BOPSY up to 2007. A foreign private capital survey (FPC) from DFI called "PRC CPE" is underway as in all Franc Zone countries. However, foreign assets of the private non banking sector are not well covered in the financial accounts as the surveys of residents' foreign assets remain very partial, and no use is made of an existing alternative source, e.g., BIS statistics. The April-May 2003 multi sector statistics mission found that the balance of payments compilation system is generally sound and encouraged the authorities to integrate banking settlement sources and disseminate the balance of payments within the recommended timeliness, as set by the GDDS. The first of these recommendations is remains pending. Annual statistics on balance of payments are reported to STA on a regular basis, but with some delay.

\section{Poverty Statistics}

The PRS Annual Update identifies a key set of poverty indicators for monitoring of the PRS implementation. 
Mali: Common Indicators Required for Surveillance

(As of April 30, 2010)

\begin{tabular}{|c|c|c|c|c|c|}
\hline & $\begin{array}{c}\text { Date of } \\
\text { latest } \\
\text { observation }\end{array}$ & $\begin{array}{c}\text { Date } \\
\text { received }\end{array}$ & $\begin{array}{l}\text { Frequency } \\
\text { of data }\end{array}$ & $\begin{array}{l}\text { Frequency } \\
\quad \text { of } \\
\text { reporting }^{7}\end{array}$ & $\begin{array}{l}\text { Frequency } \\
\text { of } \\
\text { publication }\end{array}$ \\
\hline Exchange Rates & Current & Current & $\mathrm{D}$ & M & M \\
\hline $\begin{array}{l}\text { International Reserve Assets and } \\
\text { Reserve Liabilities of the } \\
\text { Monetary Authorities }^{1}\end{array}$ & March 2010 & March 2010 & M & M & M \\
\hline Reserve/Base Money & March 2010 & March 2010 & $\mathrm{M}$ & M & M \\
\hline Broad Money & March 2010 & March 2010 & $\mathrm{M}$ & M & M \\
\hline Central Bank Balance Sheet & March 2010 & March 2010 & M & M & M \\
\hline $\begin{array}{l}\text { Consolidated Balance Sheet of } \\
\text { the Banking System }\end{array}$ & March 2010 & March 2010 & M & M & M \\
\hline Interest Rates $^{2}$ & Current & Current & I & $\mathrm{W}$ & M \\
\hline Consumer Price Index & March 2010 & April 2010 & $\mathrm{M}$ & $\mathrm{M}$ & M \\
\hline $\begin{array}{l}\text { Revenue, Expenditure, Balance } \\
\text { and Composition of Financing }{ }^{3}- \\
\text { General Government }^{4}\end{array}$ & $\mathrm{~N} / \mathrm{A}$ & N/A & & & \\
\hline $\begin{array}{l}\text { Revenue, Expenditure, Balance } \\
\text { and Composition of Financing }{ }^{3}- \\
\text { Central Government }\end{array}$ & March 2010 & April 2010 & M & Q & $\mathrm{A}$ \\
\hline $\begin{array}{l}\text { Stocks of Central Government } \\
\text { and Central Government- } \\
\text { Guaranteed Debt }{ }^{5}\end{array}$ & 2009 & Feb 2008 & $\mathrm{M}$ & $\mathrm{J}$ & $\mathrm{A}$ \\
\hline $\begin{array}{l}\text { External Current Account } \\
\text { Balance }\end{array}$ & 2009 & March 2010 & A & A & A \\
\hline $\begin{array}{l}\text { Exports and Imports of Goods } \\
\text { and Services }\end{array}$ & 2009 & March 2010 & A & A & $\mathrm{A}$ \\
\hline GDP/GNP & 2009 & March 2010 & A & $\mathrm{A}$ & Semi-A \\
\hline Gross External Debt & 2009 & March 2010 & A & A & A \\
\hline International Investment Position ${ }^{6}$ & 2007 & April 2008 & A & A & A \\
\hline
\end{tabular}

${ }^{1}$ Includes reserve assets pledged or otherwise encumbered as well as net derivative positions.

${ }^{2}$ Both market-based and officially-determined, including discount rates, money market rates, rates on treasury bills, notes and bonds.

${ }^{3}$ Foreign, domestic bank, and domestic nonbank financing.

${ }^{4}$ The general government consists of the central government (budgetary funds, extra budgetary funds, and social security funds) and state and local governments.

${ }^{5}$ Including currency and maturity composition.

${ }^{6}$ Includes external gross financial asset and liability position vis-à-vis nonresidents.

${ }^{7}$ Daily (D); weekly (W); monthly (M); quarterly (Q); annually (A); irregular (I); and not available (NA). 
July 16,2010

\section{IMF Executive Board Completes Fourth Review Under ECF Arrangement for Mali}

The Executive Board of the International Monetary Fund (IMF) today completed the fourth review of Mali's economic performance under a program supported by the Extended Credit Facility (ECF) ${ }^{1}$. The Board's decision enables the government to request a disbursement amounting to SDR 2 million (about US\$3 million), bringing total disbursements to Mali to an amount equivalent to SDR 23.99 million (about US\$36.1 million). The Executive Board also approved the modification of end-June 2010 performance criteria.

The Executive Board also concluded the 2010 Article IV consultation. Details of the findings of the Article IV will be published in a Public Information Notice in due course.

The ECF arrangement for Mali was approved in May 2008 (see Press Release No. 08/126) for an amount equivalent to SDR 27.99 million (about US\$42.1 million).

At the conclusion of the Board's discussion, Mr. John Lipsky, First Deputy Managing Director and Acting Chair, stated:

"The authorities are to be commended for the satisfactory implementation of their economic and financial program in 2009, despite the global economic crisis. The 2010 economic outlook is positive, with a projected strengthening of economic activity. Continued

\footnotetext{
${ }^{1}$ The Extended Credit Facility (ECF) has replaced the Poverty Reduction and Growth Facility (PRGF) as the Fund's main tool for medium-term financial support to low-income countries by providing a higher level of access to financing, more concessional terms, enhanced flexibility in program design features, and more focused streamlined conditionality. Financing under the ECF currently carries a zero interest rate, with a grace period of $5 \frac{1}{2}$ years, and a final maturity of 10 years. The Fund reviews the level of interest rates for all concessional facilities every two years.
}

Washington, D.C. 20431 • Telephone 202-623-7100 • Fax 202-623-6772 • www.imf.org 
commitment to prudent macroeconomic and structural reform will be necessary to reduce vulnerabilities, diversify the economy, raise economic growth, and reduce poverty.

"The authorities are implementing a modest fiscal stimulus package reflected in a revised budget law and financed by part of SOTELMA's privatization revenue. The authorities are committed to ensure full transparency in the use of the privatization receipts. Budget execution will need to be carefully monitored and the necessary savings ensured to achieve the targets for the fiscal deficit and the reduction of pending bills.

"Prudent fiscal and debt policy will be critical to reduce the Malian economy's vulnerability to external shocks. The authorities plan to streamline the tax system and broaden the tax base. They are also determined to strengthen public debt management and exercise prudence in managing and contracting external debt.

"Mali's structural reform program is making satisfactory progress, with a further strengthening of public finance management targeted in 2010. The privatization of the cotton parastatal CMDT and the reform program of the Housing Bank of Mali are on track. Nevertheless, the authorities will need to redouble their reform efforts to enhance the environment for private sector activity, improve the provision of financial services, diversify the economic base, alleviate impediments to trade, and raise productivity" Mr Lpisky added. 


\section{INTERNATIONAL MONETARY FUND}

\section{Public Information Notice}

EXTERNAL

RELATIONS

DEPARTMENT

Public Information Notice (PIN) No. 10/96

FOR IMMEDIATE RELEASE

July 23,2010

International Monetary Fund

$70019^{\text {th }}$ Street, NW

Washington, D. C. 20431 USA

\section{IMF Executive Board Concludes 2010 Article IV Consultation with Mali}

On July 16, 2010, the Executive Board of the International Monetary Fund (IMF) concluded the Article IV consultation with Mali. ${ }^{9}$

\section{Background}

As a landlocked Sahelian country of 14 million people, Mali has struggled to overcome low social indicators and high poverty rates. Since the democratic transition of the early 1990s, it has posted steady economic growth of around 5 percent per year. Macroeconomic stability is reinforced through membership in the West African Economic and Monetary Union (WAEMU). However, Mali's dependence on a few export commodities and its susceptibility to drought and other natural disasters has left it highly vulnerable to economic shocks.

Macroeconomic performance has been generally good during the past two years. Mali's agriculture-based economy has weathered the global economic storm well. Its growth rates have been among the highest in the WAEMU region in the last 5 years, and real gross domestic product (GDP) grew by $4 \frac{1}{2}$ percent in 2009 . Goods harvests, reflecting favorable weather and supportive policies, have positively affected growth. The drop in crude oil and food prices have contributed to a sharp reduction in inflation. Fiscal performance in 2009 was slightly better than expected, but the targeted reduction in pending bills and domestic arrears was not fully achieved until March 2010. The external accounts benefited from buoyant gold prices and the decline in oil and food prices, as well as the equivalent of

\footnotetext{
${ }^{9}$ Under Article IV of the IMF's Articles of Agreement, the IMF holds discussions with each member, usually every year. A staff team visits the country, collects economic and financial information, and discusses with officials the country's economic developments and policies. On return to headquarters, the staff prepares a report, which forms the basis for discussion by the Executive Board. At the conclusion of the discussion, the Managing Director, as Chairman of the Board, summarizes the views of Executive Directors, and this summary is transmitted to the country's authorities. An explanation of any qualifiers used in summing up can be found here: http://www.imf.org/external/np/sec/misc/qualifiers.htm.
} 
$51 / 2$ percentage points of GDP in exceptional external resources (privatization receipts and the Special Drawing Rights (SDR) allocations).

A number of structural reforms were carried out in 2009. Telecom provider SOTELMA was successfully privatized; a tender was launched to sell state cotton ginner CMDT; and progress was made in restructuring the housing bank, BHM, prior to a planned 2012 privatization. The new multidonor public financial management (PFM) reform program, PAGAM II, will be launched shortly, but previously-identified PFM reforms have continued.

Mali's 2009 debt sustainability analysis, carried out jointly with World Bank staff, assessed Mali's risk of debt distress to be low. However, that analysis identified a number of risks, notably the risk from the uncertain prospects from the mining sector and the risk from the potential debt burden should Mali choose to borrow abroad on nonconcessional terms.

\section{Executive Board Assessment}

Directors commended the authorities for their strong economic performance, supported by sound macroeconomic management and favorable harvests and export prices. Directors noted that continued commitment to prudent macroeconomic policies and structural reform will be necessary to reduce vulnerabilities, diversify the economy, and reduce poverty.

Directors supported a limited fiscal stimulus in 2010, focusing on public investment and other priority spending. In this context, they emphasized that further improvement in transparency in budget planning and execution is crucial. Directors regretted the build-up of pending bills, and recommended further efforts to strengthen cash management and address the long-standing issue of VAT credit arrears. They also encouraged further progress in broadening the tax base and improving revenue administration. Given the uncertainties surrounding Mali's export prospects, Directors called on the authorities to devote particular attention to strengthening debt management to avoid the risk of debt distress.

Directors concurred that the continued strong implementation of structural reforms remains important to strengthen the economy's competitiveness and raise growth potential. They noted the recent good progress in this area, but encouraged further efforts to enhance the business climate, improve the provision of financial services, and boost private sector-led growth.

Directors welcomed the authorities' efforts to incorporate the 2008 FSAP recommendations into their financial sector development plans. They also commended the authorities for taking steps to strengthen the AML-CFT regime. Directors encouraged the authorities to strengthen statistical capacity, particularly in the area of public finance and balance of payments statistics.

Public Information Notices (PINs) form part of the IMF's efforts to promote transparency of the IMF's views and analysis of economic developments and policies. With the consent of the country (or countries) concerned, PINs are issued after Executive Board discussions of Article IV consultations with member countries, of its surveillance of developments at the regional level, of post-program monitoring, and of ex post assessments of member countries with longer-term program engagements. PINs are also issued after Executive Board discussions of general policy matters, unless otherwise decided by the Executive Board in a particular case. 
Mali: Selected Economic and Financial Indicators, 2008-12

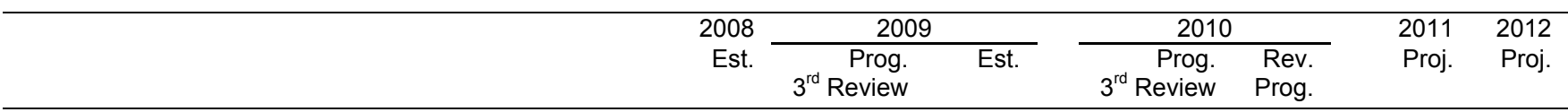

National income and prices

Real GDP

GDP deflator

Consumer price inflation (average)

External sector (percent change)

Terms of trade (deterioration -)

Real effective exchange rate (depreciation -)

Money and credit (contribution to broad money growth)

Credit to the government

Credit to the economy

Broad money (M2)

Investment and saving

Gross domestic investment

Of which: government

Gross national savings

Of which: government

Gross domestic savings

Central government finance

Revenue

Grants

Total expenditure and net lending

Overall balance (payment order basis, excluding grants)

Basic fiscal balance ${ }^{1}$

Underlying basic fiscal balance ${ }^{2}$

External sector

Current external balance, including official transfers

Current external balance, excluding official transfers

Exports of goods and services

Imports of goods and services

Debt service to exports of goods and services

External debt (end of period)

\section{Memorandum items:}

Nominal GDP (CFAF billions)

Overall balance of payments (US\$ millions)

Money market interest rate in percent (end of period)

Gross international reserves (US\$ millions)

Central Bank of West African States (BCEAO)

in percent of broad money

in months of imports

BCEAO Mali (imputed) ${ }^{3}$

in percent of broad money

US\$ exchange rate (end of period)

$\begin{array}{rrrrrrr}4.9 & 4.3 & 4.5 & 4.8 & 5.1 & 5.3 & 5.8 \\ 8.8 & 4.3 & 3.6 & 2.6 & 3.6 & 3.0 & 2.4 \\ 9.1 & 2.2 & 2.2 & 1.2 & 2.1 & 2.6 & 2.8 \\ & & & & & & \\ -1.9 & 27.2 & 23.7 & -8.4 & 6.6 & 4.3 & -1.7 \\ 8.0 & \ldots & 0.3 & \ldots & \ldots & \ldots & \ldots \\ & & & & & & \\ -3.2 & -7.6 & -13.9 & 5.3 & 10.4 & 5.0 & 2.1 \\ 5.2 & 5.6 & 7.2 & 6.9 & 5.7 & 5.4 & 6.7 \\ 0.5 & 15.3 & 16.0 & 10.5 & 16.7 & 9.4 & 8.2\end{array}$

(in percent of GDP, unless otherwise stated)

$\begin{array}{rrrrrrr}20.7 & 18.4 & 18.2 & 19.7 & 20.0 & 21.0 & 21.5 \\ 5.7 & 6.8 & 6.7 & 7.2 & 7.5 & 7.6 & 7.2 \\ 7.8 & 12.2 & 8.6 & 11.7 & 12.1 & 11.8 & 12.4 \\ 1.8 & 1.2 & 0.8 & 0.5 & 1.5 & 1.5 & 1.6 \\ 6.2 & 10.7 & 7.0 & 9.9 & 10.3 & 12.1 & 13.1\end{array}$

15.5

3.4

21.2

$-5.6$

$-1.0$

$-1.0$

$-12.9$

$-14.1$

28.5

$-43.1$

4.0

19.1

3,913

$-10.3$

4,248

6.8

10,721

55.0

6.1

1,033

48.6

481.5

$27.5 \quad 26.0$
419.6

4,232

448.0

$16.6 \quad 17.1$

$4.9 \quad 4.1$

$24.7 \quad 24.1$

$-8.0 \quad-6.9$

$-1.8 \quad-1.4$

$-1.4 \quad-0.8$

$-6.1 \quad-9.6$

$-8.2 \quad-11.9$

$-35.2 \quad-37.2$

$4.0 \quad 4.2$

$20.2 \quad 19.3$

...

13,631

$\begin{array}{lr}\cdots & 13,631 \\ \ldots & 58.7\end{array}$

$\begin{array}{rr}\cdots & 6.9 \\ \ldots & \end{array}$

$1,637 \quad 1,602$

$64.4 \quad 60.6$

$464.5 \quad 449.3$

\section{8}

\section{.7}

\section{.1} 7 


\section{Statement by Laurean W. Rutayisire, Executive Director for Mali}

\section{July 14, 2010}

1. My Malian authorities continue to value the advice provided by the Fund and its staff as they advance the policy and reform agenda set forth in Mali's economic program supported by the Extended Credit Facility (ECF). They are appreciative of the policy dialogue they have held with staff and Management in Bamako and Washington in recent months and look forward to maintaining a close and productive working relationship with the Fund so as to facilitate further progress toward program objectives.

2. The 2010 Article IV consultation provides yet another welcome opportunity for the authorities to appreciate staff's insight on the key policy challenges facing the country. Key among these challenges is the need to achieve higher rates of economic growth so as to significantly reduce poverty and make headway towards attainment of the Millennium Development Goals, as reaffirmed in last year's progress report of the authorities' growth and poverty reduction strategy which outlines the key policy measures that are envisaged to achieve this objective. The authorities are also aware of the importance of carefully managing public debt and further strengthening the country's resilience to external shocks, as advised by the staff. They are hopeful that substantial progress will continue to be made on these fronts notably through continued adherence to prudent debt and fiscal policies and implementation of the ambitious public investment program partly financed by SOTELMA privatization proceeds.

\section{Recent Economic and Program Performance}

3. As noted in the authorities' letter of intent, the authorities have laid the foundations of Mali's strong economic performance in 2009 by sticking to the implementation of prudent macroeconomic policies embedded in the ECF-supported program. Partly as a result, the economy of Mali has continued to grow at a relatively high level amid the recent global economic and financial crisis, overperforming that of many comparable countries. After peaking in the last quarter of 2008, consumer price inflation has since been contained below 3 percent. Fiscal performance was satisfactory as noted by staff with the basic fiscal deficit being held below the program target. The external current account balance improved significantly, as gold export prices rose and external conditions became more favorable.

4. Mali's performance under the current ECF arrangement continues to be strong. As was the case at the time of the third ECF review, performance on the quantitative front has been irreproachable, with all performance criteria set for the test date set of the current review being met. Economic management has thus continued to be sound during the period covered by the review. In particular, net domestic financing and net tax revenues were respectively below and above target; and external debt was managed prudently, with no external payments arrears being accumulated and no external nonconcessional borrowing contracted.

5. As noted by staff, the structural reform program proceeded satisfactorily. All but one structural benchmarks set for this fourth ECF review were observed, thus enabling the 
authorities to make further inroads in the implementation of their reform agenda. More specifically, the authorities finalized a strategy for the restructuring of the housing bank, BHM, as well as a study on the macroeconomic impact of the gold sector. At the same time, they worked jointly with monetary authorities to better grasp the net position of the government vis-à-vis the banking system and to establish an appropriate framework for recording transactions in the government's financial accounts. Overall, this structural performance thus translated into enhanced quality of public finance statistics, increased resilience of the banking system, and better understanding the macroeconomic incidence of the depletion of known gold reserves.

6. However, the one missed benchmark relates to the planned establishment of a monitoring system for the budgetary float which did not take place according to schedule, as it hinges on the ongoing implementation of a new public accounting system. Meantime, the authorities will continue to abide by the existing alternative system of monitoring the budgetary float through the expenditure chain. It is also noteworthy that a sharp decline in the budgetary float was registered in the first quarter of the current year in line with the authorities' program commitment although the float reduction did not meet program expectations at the end of 2009 following higher spending and delays in the disbursement of external assistance during the last quarter of that year.

7. In view of the programmed use of SOTELMA privatization proceeds and the planned reduction of pending bills in 2010, the revision of the quantitative criteria and benchmarks initially set for June 2010 was warranted. In this regard, we would appreciate Board approval of the authorities' request for this modification.

\section{Policy and Reform Agenda for the Rest of 2010}

8. Prudence will continue to guide the authorities in the conduct of fiscal policy. The 2010 supplementary budget law submitted to the Parliament embodies a prudent fiscal stance with the underlying basic deficit — excluding expenditures financed by SOTELMA privatization proceeds - being kept in the neighborhood of 1 percent of GDP. As we reported at the time of the third ECF review, the authorities' commitment to a transparent use of SOTELMA privatization proceeds remains unwavering. These resources are deposited in a Treasury account open at regional the central bank, thus facilitating the tracking of their use.

9. The strong revenue performance that has been recently registered is also expected going forward, as the authorities will adhere to continuous implementation of to revenueenhancing measures. In particular, the streamlining of the tax system is envisaged with the aim at boosting revenue mobilization along with the broadening of the tax base, rationalization of the tax legislation, and the review of existing tax exemptions. In support of these efforts Fund technical assistance in the area of tax administration will remain critical.

10. The authorities will persevere in their efforts to strengthen public debt management. In this connection, while taking necessary steps to clear VAT credit arrears due to mining companies, the authorities also intend to put in place a framework that enables timely reimbursement of VAT credits and prevent recurrence of such arrears. Moreover, the recently established debt management committee will play a crucial role in reviewing ex-ante the 
government's borrowing plans and ensuring timely access to regional financial markets. By the same token, the authorities will continue to abide by their demonstrated commitment to prudence in managing and contracting external debt.

11. Strengthening public financial management (PFM) remains a cornerstone of the authorities' structural agenda. As the action plan for improving and modernizing PFM (PAGAM/GFP) has been successfully implemented, work is underway to develop a new PFM reform program that builds on progress already made and aims notably at further improving budget preparation and execution. The planned introduction of a new public accounting system at the Treasury will also play a key role in better monitoring budget execution and reporting of government's financial transactions.

12. With regard to the financial sector, preliminary data show that financial soundness indicators for Mali's banking sector broadly improved in 2009, as reported in Table 11 of the staff report. In particular, capital adequacy ratios and profitability of the banking sector improved while nonperforming loans in percent of total loans declined. These positive developments notwithstanding, financial sector reform will continue to proceed in line with the authorities' financial sector development strategy. In particular concrete actions are envisaged in the coming months to advance the restructuring of BHM, including the selection of a privatization advisor tasked with evaluating the impact of the measures that have already been taken by the authorities as part of the bank's restructuring plan.

13. Reform of the cotton sector is another area in which the authorities are determined to make further inroads. This reform remains overshadowed by the privatization process of the cotton ginning company, CMDT. Mindful of its implications for the viability of the sector, the authorities are taking prudent but decisive steps to that resolve, notably by developing a strategic framework for the development of the cotton sector.

14. Based on Mali's satisfactory program implementation and the authorities' determined commitment to the program, we would appreciate Directors' approval of the proposed decision and completion of the current ECF review. 